\title{
INTEGRATION OF TRADITIONAL AND INNOVATION PROCESSES IN MODERN PEDAGOGY AND PSYCHOLOGY
}

Collective monograph

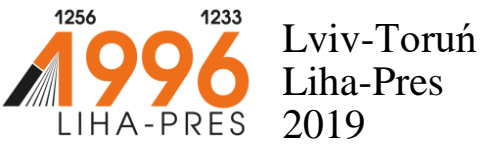


Reviewers:

Prof. nadzw., dr hab. Stanistaw Kunikowski, Rektor of Cuiavian University in Wloclawek (Republic of Poland);

Prof. $d r$ hab. Kazimierz Pierzchala, Katolicki Uniwersytet Lubelski/Catholic University of Lublin (Republic of Poland);

Prof. dr hab. Stanistaw Juszczyk, Uniwersytet Ślaski / University of Silesia (Republic of Poland).

Integration of traditional and innovation processes in modern pedagogy and psychology : collective monograph / V. Afanasenko, L. Aleksieienko-Lemovska, Z. Karpenko, O. Melnyk, etc. - Lviv-Toruń : Liha-Pres, 2019. - 192 p.

ISBN 978-966-397-161-2

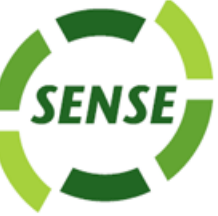

\begin{abstract}
Liha-Pres is an international publishing house which belongs to the category "C" according to the classification of Research School for Socio-Economic and Natural Sciences of the Environment (SENSE) [isn: 3943, 1705, 1704, 1703, 1702, 1701; prefixMetCode: 978966397]. Official website www.sense.nl.
\end{abstract}




\section{CONTENTS}

DEVELOPMENT OF PERSONAL CREATIVE

POTENTIAL IN ONTOGENY

Valentyna Afanasenko

1

METHODOLOGIKAL COMPETENCE OF PRE-SCHOOL TEACHERS IN THE PROFESSIONAL PEDAGOGICAL COMPETENCE STRUCTURE

Liudmyla Aleksieienko-Lemovska .26

MOBBING IN ORGANIZATIONS: THE TYPOLOGICALSTRATEGIC APPROACH

Zinoviia Karpenko 49

FEATURES OF UNDERSTANDING THE HUMAN

MENTAL DEVELOPMENT IN THE VIEWS OF THE

REPRESENTATIVES OF THE SCHOOL

OF PHILOSOPHY OF PSYCHOLOGY

OF THE LATE XIX - EARLY XX CENTURY

Oksana Melnyk 70

METHODS OF RESERCH

OF EMOTIONAL INTELLIGENCE

Mariia Stasiuk .97

THE GENESIS OF THE RESEARCH

OF DETERMINANTS OF PROFESSIONAL

STABILITY OF A FUTURE PSYCHOLOGIST'S

PERSONALITY: CONCEPTUALIZATION

AND EMPIRICAL REFERENTS

Hanna Varina.

AREAS OF ACADEMIC STAFF TRAINING IN UKRAINIAN DOMESTIC UNIVERSITIES (1863-1900)

Iryna Tamozhska 
ASSESSMENT AS ONE OF THE FACTORS

OF THE IMPACT ON THE CHILD'S

SELF-ESTEEM FORMATION DURING

THE SCHOOL ADAPTATION PROCESS

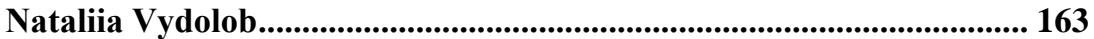


DOI https://doi.org/10.36059/978-966-397-161-2/1-25

\section{DEVELOPMENT OF PERSONAL CREATIVE POTENTIAL IN ONTOGENY}

\section{Valentyna Afanasenko}

\section{INTRODUCTION}

Human vitality in a network society, relevance to non-linear innovative and unpredictable processes of life that include variety of changes and scenarios are based on a unique resource - the personal creative potential. It combines uniqueness and universal capacity for development that leads to quality transformation, new activity and updating. Creativity as an activity implies that the old and the new become action forms. However, creativity is not just a new activity but a qualitatively new performance based on the reorganization of activity.

If the activity is focused on its intensity without demonstrating meaningful signs of transformation and does not lead to the emergence of a qualitatively new product, it is a way of the world development in the form of human activity. Therefore, creativity as a human activity involves capacity for development due to which qualitatively new results appear. Its value is not only in the absolute newness emerging in the process of human activity, but mainly in discovering something new for the self and in the self regardless of its novelty to others. Moreover, the concept "new" is quite ambiguous.

The problem of the creative personality in the diachronic dimension has a priority status in the system of knowledge about the human. Theoretical praxeological and research of its development were contributed by F. Barron, M. Berdiaev, A. Bergson, J. Guilford, V. Gordon, A. Maslow, K. Rogers, C. Taylor, R. Torrens, V. Frankl, S. Freud and others.

The development process of a creative personality is analyzed as a multidisciplinary problem in various aspects: the correlation of intellectual abilities, creative qualities and thinking of the individual 
(V. Andreev, I. Kon, T. Kudriavtsev, V. Moliako, E. Moren, G. Lindsey, J. Piaget, B. Teplov, K. Hall, etc.),

Currently the phenomenon of "creative potential" is relevant and used in various spheres of human existence as the basic concept in the anthropocentric paradigm. However, it has latent nature and nonlinear development. Therefore, scientific and psychological analysis of ego development is valuable in this sense as it is the basis for presenting the features of the creative potential development.

\section{Concepts of personality development in scientific researches of the XX century}

The concept of development as a linear progress has changed under the influence of the of phenomenology and existentialism ideas in the 20th century. "Here-and-now" principle integrating the past, present and future becomes the initial one; it brings together various structures of the constantly evolving world and the person capable of self-development.

Experiencing different history states is typical for the nonclassical philosophy paradigm. These states follow each other and simultaneous stay in all of them constitutes the wholeness of being in three temporal dimensions.

M. Heidegger analysed it through the past and the future in the present ${ }^{1}$. Such understanding of time in its development involves the formation of the universum wholeness in the sequence of its events, integrating all its moments and history states.

In postmodern philosophy, different interpretations of development exist. Thus, in the concept by H. Shchedrovytskyi it is defined through self development, a qualitative change of the object, substance (nature, activity, mental activity). In his methodology, development is interpreted as the change of the sequential history states of the system object ${ }^{2}$. Each successive state is genetically linked

${ }^{1}$ Heidegger, M. (2003) Bytie i vremya [Being and time]. Kharkov, Ukraine: Folio. (in Russian)

2 Shchedrovitskyi, H. (1995) Izbrannye Trudy [Selected works]. Moscow, Russia: Shkola kulturnoi politiki. (in Russian). 
to the previous one in its structure. Development is the transition from the structure of one quality to the structure of another. It is emphasized that the object is developed not partly but its parts are formed depending on the change of the whole object. According to the authors, seeing "qualitative", genetically conditioned changes in the structure of the whole object can only be based on the system of standards that allows to estimate the development and adequate stepby-step marking. Development is interpreted not as a natural time indicator, but as the vital activity of the development object itself; it is an immanent process with the source embedded in the object itself.

In the concept of developmental education by V. Davydov ${ }^{3}$ development is interpreted as the abilities formation by means of performing activities in various fields. The author's concept is aimed primarily at the formation of the student's personality, actualization of their personal agency, thinking skills, the ability to learn by creating situations for solving problems. The students work out the concept that contributes to their theoretical thinking development and aims to reproduce wholeness of the object, its history, its genesis and development using the convergence. Working out of the theoretical concept in particular constitutes the method of convergence, since it maps an object from its individual element to the specific developed whole. The weak point of this concept is insufficient consideration of the individual learning trajectory of each student.

L. Vygotsky ${ }^{4}$ interpreted the process of cultural development as mastering the behavior while generating personal agency and forming special personal structure consisting of internalized cultural means. According to L. Vygotsky, the source of human cultural development is concentrated in its very nature and organism that is imperfect and underdeveloped in comparison with the organism of animals. Cultural development is considered as a special process of "ingrowing" of the

3 Davydov, V. (1996) Teoriya razvivayushchego obucheniya [Theory of developing education]. Moscow, Russia: INTOR. (in Russian)

${ }^{4}$ Vygotsky, L. (1982) Sochineniya. [The collected works]. Moscow, Russia: Pedagogika. (in Russian). 
person into the culture, that implies gradual behavior mastering. Personality formation is its prerequisite that provides newly formed structures connected to the developmental age. The author considers consciousness as the "integral expression" of the highest, most essential features of the personality structure. Age transitions take place on the basis of the consciousness restructuring.

L. Vygotskyi explains that changing of social situations of development leads to the personality development and age-related transitions. The game is a cultural form of development due to the semantic field that it creates. Staying free in this semantic field becomes a priority for the person. The author determines cultural age of the person by the age of freedom as development is based on the freedom development.

Periodization of the child's development by D. Elkonin ${ }^{5}$ is build on the logic of activity vectors. First, he identifies the period of the motivation and needs development in the activity (i. e. work with the meaning). It is followed by the development of operational and technical side of the personal activity. They periodically dominate and interchage. Different chronological ages distinguish a certain type of activity with different types of mediation. In some of them person-to-person relations are mediated by subjects, in others - person-to-subject relations are mediated by people. According to D. Elkonin leading activities belong either to the first (motivational group) or to the second (operationaltechnical group) types of activities. The leading type of activity determining age periodization is typical for each age. Thus, development depends mainly on activity but not personality itself.

V. Slobodchikov ${ }^{6}$ interprets the personal development as the development of person's natural abilities. Considering this process as the history of the human subjectivity evolution, he offers a map of

${ }^{5}$ Elkonin, D. (1994) Vvedenie v psikhologiyu razvitiya [Introduction to the developmentl psychology]. Moscow, Russia: Trivola. (in Russian)

${ }^{6}$ Slobodchikov, V. (1991) Kategoriya vozrasta $v$ psikhologii i pedagogike razvitiya. [Category of age in psychology and pedagogy of development]. Voprosy psikhologii, no. 2. pp. 37-49. 
development for tracing the individual trajectories of the person's dynamics. As V. Slobodchikov notes, this periodization is an epigenetic combination presenting all ages simultaneously. The author's view does have sense as no end can be found to any age period in a lifetime as well as no age crisis can be fully resolved during life. In addition, the sequence of ages is not considered to be inviolable for everyone. V. Slobodchikov relies on the original "general law of living systems development"; each of them is formed and developed according to their own laws. A closed "life cycle"is formed of the stages of birth, maturation, peak and dying where each of them can distinguished.

B. Elkonin ${ }^{7}$ explains development as a simultaneous movement, retention of the original and reproduction of the initial state, illustrating the correlation of real and ideal forms. The reproduction of the initial state means the reflection of the ideal form or image based on the well-being, as the fullness of the own activity without any needs and desires to satisfy them. The object of activity here is the activity itself, the full state of well-being; it is achieved throughthe person's vertical coordination of the horizontal breaks, parts and incoherence.

All the reviewed concepts are to some extent limited by subjectrelated activity. Development is studied in the context of the subjectrelated activity and thinking components; this approach is based on the ideas of subjectivity and creativity: the person creates the world of subject-related activity and lives in it, and through this world they create themselves, their "inorganic body". Swiss biologist and philosopher J. Piaget $^{8}$ developed the theory of intellectual development from infancy to maturity. Piaget's main focus is on the development of logical thinking; thus the stages of intellectual development were determined: sensomotor, pre-operative, specific

${ }^{7}$ Elkonin, D. (1995) Psikhicheskoe razvitie v detskikh vozrastakh. [Psychic development in child age]. Moscow, Russia: Institut prakticheskoi psihologii. (in Russian)

8 Piaget, J. (1994) Izbrannye psikhologicheskie trudy [Selected works in psychology]. Moscow, Russia: Mezhdunarodnaia pedagogicheskaia academia. (in Russian) 
operations and formal operations. The theory of cognitive development is fragmentary, since intellectual potential is a component of the personal creative potential.

The theory of positive disintegration by K. Dambrowski ${ }^{9}$ is of big heuristic value for the study of personality development; its basic idea is that the person is capable of continuous development, and even is bound to develop. The process of continuous personality development involves biological phases and socio-psychological levels and goes on due to the individual's system of internal tendencies and dynamics (single or multilevel, hierarchical or equivalent, harmonious or contradictory).

Development potential is a resource of constant movement and change of the personality under the influence of the hierarchy of intrinsic values and motivation. The author identifiesits features such as sensitivity, interests, abilities, etc.

The explication of the development process through the mechanisms of positive disintegration is worth analyzing. Disintegration is explained as the open long-life process that has no principal completion. Positive disintegration is found in weakening, breaking of the original integrity and coherence because of destroyed links between the structure elements or the original structure breakdown. The process of positive disintegration takes place in ontogeny, in neuroses, psychoneuroses, in external (social, interpersonal) and internal conflicts. Positive disintegration is the process that ensures the dynamics of personal creative growth. Its important starting point is the "positive maladaptation" of the person to reality. In such maladaptation the author sees signs of a unique creative character of the personality which reflects its independence development. K. Dambrowski considers increased mental excitability, internal conflicts and crises, fears, depressions, etc., as indicators of dissatisfaction with stable reality and actualization of the need to search for another reality, different from the daily monotonous and

${ }^{9}$ Dambrowski, K. (1977) Multilevelness and Positive Disintegration. New York : Dabor science. 
boring one. This way the need to overcome phase connections is realized: the personovercomes this biological cycleby their choice. The author is convinced that the person has no other way but to potentially developthrough thishard work.

Going beyond the biological phases of development implies the evolution of self-reflection andemergence of internal conflicts.It is the basis for person's defence mechanisms awareness and emotional maturation that leads to the increase of empathy, internal independence, the need of personal interaction, etc. The development of personal consciousness does not depend on the biological phases and is mainly connected with overcoming their own mental type, i.e going beyond stability. Conscious internal restructuring, selfeducation, and self-psychotherapy play a leading role in the transition from subordination to automatisms (meaning self-regulation based on defence mechanisms) to the organization of individual program of internal changes including hierarchy of needs, values and goals.

The phenomenon "positive maladaptation" in K. Dambrowski's theory indicate organizational processes of the individual creative potentialaccompanied by maladaptation, inadequate behavior due to de-actualization of standard defence mechanisms. Further development of the individual is not determined by psychobiological factors only as a conscious transition to the "human" path of development takes place. It is presented as a 5-level cycle:

$1^{\text {st }}$ - primary integration;

$2^{\text {nd }}-$ one-level disintegration;

$3^{\text {rd }}$ - spontaneous multilevel disintegration, impulsive and insufficiently organized;

$4^{\text {th }}$ - systematic and multi-level organized disintegration;

$5^{\text {th }}$ - secondary integration (level of personality per se).

The first level and the starting point of further levels of development is described by the author as the primitive coherence of instincts with subordinate intelligence; unilateral intellectual development with underdeveloped feelings. According to K. Dambrowski, the first level is peculiar to most so-called ordinary people, as well as those who are on the verge of psychopathy and 
psychopathology. Aggressiveness, agility, and dynamism are typical for them. Their own interests are dominating and lead to making quick decisions using other people for achieving their own goals.

At one-level disintegration, the person is focused on the standards of the outside world, having doubts, hesitation, and uncertainty when making traditional decisions. Emotional relationships with others can be addictive. Internal conflicts are the result of a case or superficial impulses, not an internal struggle. Strong emotional conflicts, reactive states, impulsive actions lead to mental breakdowns. Due to the weakening of the primary integrative structure, in case of the absence of a formed hierarchy of values, psychoses, phobias, psychosomatic disorders, alcoholism and drug addiction are possible. Sensitivity can lead to degradation. As K. Dambrowski notes: "All this often leads to suicides and mental disorders"10.

At the level of multilevel spontaneous disintegration, extensive differentiation of psychic structures and functions is noticeable. The behavior is caused by internal processes; uncertainty is replaced by a perspective feeling of "what should be" as opposed to existing in the personality structure. This understanding is the source of the strongest impulses of development, the phase of true humanization of psychic functions. It is characterized by internal doubts, tensions, anxiety, fear, depression, etc. The author considers determining of values and the forming of their hierarchy to be the main impetus for development. Emotional connections become more selective and tend to be exclusive; internal conflicts as a reflection of the hierarchical organization of emotional life are typical. Forces that have a transformative effect (dynamisms by $\mathrm{K}$. Dambrowski) provoke astonishment and concern of the person about themselves and their surroundings, dissatisfaction with themselves, feelings of inadequacy, shame and guilt; positive maladaptation, creative tension. Usually, such reactions are considered psychoneurotic, abnormal, but

${ }^{10}$ Dambrowski, K. (1977) Multilevelness and Positive Disintegration. New York : Dabor science (p. 27). 
K. Dambrowskidescribes such mental states as the capacity for internal mental development and signs of mental health. K. Dambrowski's research and experience of clinical work prove the progressive character of most psychoneurotic processes. At the level of spontaneous disintegration, special "immersion" into person's own increased excitability, positive maladaptation, psychoneurosis of fear, depression takes place. Instead, the dynamism of development through self-observation, self-esteem, comparison with other people is actualized. Objectivation of self is inversely proportional to subjectivation towards other people, in the sense of treating them not as a means, but as the living person. At this level, internal regulation is made by the "third factor", i.e a complex dynamism derived from many factors operating at the same or at lower stages. It is a complex of mental states associated with the person's active attitude to themselves and to the environment. They gradually form autonomous and authentic factors, which fully fulfill the task of person's development and their life choice at the highest levels of mental development. The first factor represents heredity and its development potential; the second factor is the influence of the environment, social one in particular.

When the internal psychic environment is formed, the elements that gradually make up the "third factor" appear. For example, at the level of spontaneous disintegration, it is feeling of guilt and shame, self-dissatisfaction, anxiety, desire for creativity. K. Dambrowski notes that from a scientific point of view it is difficult to determine the source of the emergence and development of the "third factor". Some scientists look for it in heredity or sociality.

At the level of systematic and multilevel organized disintegration, self-control, self-education and autopsychotherapy are important. Self-control regulates development and impedes the processes that hinder it; self-education implements the systematic development program; autopsychotherapy is a kind of self-education in periods of conflict and psychoneurosis. At this level of development, empathy as compassion and love involves willingness to protect others, to help them; identification means adequate empathic 
feeling, understanding and accepting of the feelings and concerns of other, often totally different, people; a focus on self-improvement involves working on the person themselves rather than criticizing others; internal conflict reflects the contradictions in the pursuit of excellence.

The process of development at the fourth level involves the transformation of the due into the real. Secondary integration dynamisms, in particular responsibility for solving socially important tasks, are beginning to take effect; autonomy based on belief in the person's own internal progress reveals in affirmation themselves at the highest levels; empathy, responsibility, autonomy, authenticity, high level of social consciousness. In the process of multi-level restructuring of subordination, the dynamism of the lower levels is replaced by the balance and autonomy of the higher levels. The lower levels break up and become excluded from the secondary integration structure. At the same time, their disappearance makes returning to lower levels of functioning impossible.

At the stage of secondary integration, as the highest level of development, the process of progressive synthesis leads to harmonious unity, which is a function of the "most complete embodiment of the ideal". Internal conflict no longer exist because the due becomes the real. According to K. Dambrowski, integrity, harmony, high level of self-reflection, consciousness, the ability to self-choice, selfconfidence, assurance in the value of own goals, awareness of the development incompleteness and the need for constant development are the main characterictics of the personality.

At the development peak the person is guided by the "personal ideal" which is based on the permanent norms and qualities of people which were approved and realized by mankind at the dawn of its culture and are considered unconditional. They manifest themselves through the history of mankind, accumulating mainly in famous historical figures.

The resercher's viewpoint about the development incompleteness regardless of the level of ideal achievement, and professional generelized description of the factors of personality states 
dynamics at different levels of development are exceptionally important.

\section{The Ego Development Model as a Basis for Explication of the Development of the Personal Creative Potential}

The model of development as a unity of discontinuity and continuity is presented in the comparative theory of the ego development by $\mathrm{J}$. Loevinger ${ }^{11}$. Among modern theories of development, it is considered to be an adequate basis for explicating the creative potential development of the individual.

The theoretical model by J. Loevinger highlights a series of successive stages of ego development. The author does not try to attach them to the chronological age of the person, however she admits they set a clear logic of development and build a hierarchy that further reflects personal maturity. Some stages are regarded as major, others as transitional. Each stage is presented as a complex structure having features of managing impulses, interpersonal relationships and awareness of the cause of behavior. The boundaries between the stages are indistinct. If the psyche gets stuck at a certain stage, the last of the genetic characteristics becomes individually-typological.

The researcher starts studying the ego development from the pre-social stage, when the gradual separation of baby's ego out of the outside world happens. In this process, reality as a stable space of external objects is constructed along with ego that exists independently of them. "The child who stays at a stage where ego is not separated from the world of inanimate objects longer than it should be is called autistic" ${ }^{\prime 2}$. The creative potential at this stage is focused on the unconscious level of the psyche. Consequently, autism at this stage is the evidence of the dominance of creative potential. Self-regulation process preserves the stability of its initial state, primary unity.

11 Loevinger, J. (1976) Ego development: conceptions andt heories. SanFrancisco: Jossey Bass Publishers.

12 Loevinger, J. (1976) Ego development: conceptions and theories. SanFrancisco: Jossey Bass Publishers (p. 15). 
At the symbiotic stage, the separation of the ego continues. Symbiotic relationship of the child with the mother or replacing her person is crucial in this period. This process is greatly facilitated by language; in particular estranged and neglect vocabulary disrupts the stability of the symbiotic relationship. Thus, the word "no" which is the key and most commonly used tool in symbiotic disintegration with further actualization of the activity limits moving to the next stage.

For impulse stage, the child's creative potential is manifested in impulsive activity and in typical individual-age sexual acts. However, J. Loevinger points out that cognitive preconditions appear for the development of causal relationships. Fixation at this stage determine the unmanageability and inadequacy of the child's actions. Such features, presumably, are caused by disintegrative dynamics and inconsistency of processes of self-regulation and self-organization. The increasing activity of the self-organization process gives a feeling of self-power and the ability to embody it in spontaneous activity; it is followed by the feeling of primitive satisfaction based on ventilation. The lack of proper regulation results in the destructive nature of the child's actions.

The child asserts their own identity on the basis of a sense of potential individual strength. Their actions are of non-standard, original, unique and perform the catharsis function. Analyzing the content of the ego development at the impulsive stage, J. Loevinger notes that to make the transition to the higher level, the child must understand, "that each thing has causes or reasons, that impulse is not the same as action, so it is possible to postpone the action and control it at least for a short time ${ }^{13}$.

The next transitional stage is a self-defense stage. The child receives their first social and psychological experience when important adults react to their behavior. External regulation of the child's individual activity increases the internal tension and actualizes the process of creative potential self-regulation. Peculiarities of ego and

13 Loevinger, J. (1976). Ego development: conceptions and theories. SanFrancisco: Jossey Bass Publishers (p. 178). 
creative potential self-regulation in this period are connected with psychological defense mechanisms actualization. The term "defense mechanisms" was used by S. Freud to define all mechanisms that weaken the dialectically unified internal-external conflict and regulate individual behavior.

A. Freud ${ }^{14}$ considered the defense mechanisms as a product of age development, unconscious ways of reaching a compromise between opposing forces of Id and the Superego and external reality. The first child's psychological defense is connected with the negative experience of their spontaneous self-expression. Inability to respond arbitrarily causes psychological tension, generating anxiety and destabilization of the Ego image. Under the influence of defense mechanisms destructive impulses are blocked or transformed. Psychological defenses are appropriate when forms of communication and conflict with the environment are limited by the level of personal development. They promote automatic adaptation to the environment through self-protection. Every child's defense mechanism is initially formed to cope with specific instinctual desires. Thus it is related to a particular phase of individual development.

E. Romanova ${ }^{15}$ explains defense mechanisms as primary intrapsychic formations that are caused by the restriction of the child'sspontaneous expression. In the early stages of ontogeny, adults are particularly intense in limiting the expression of the child's desires, thoughts and feelings. It leads to external conflict which is further internalized. Defense mechanisms are indirect ways of experiencing and coping with emotional conflict.

Gradually, the child begins to anticipate encouragement and punishment in the immediate future but the child is not able to adequately control their own behavior yet; and the need for defense

${ }^{14}$ Freud, A. (1993) Psikhologiya «Ya»i zashchitnye mekhanizmy [The Ego and the mechanisms of defense]. Moscow, Russia: Prosveshchenie. (in Russian)

15 Romanova, E. (1996) Mekhanizmy psikhologicheskoy zashchity: genezis, funktsionirovanie, diagnostika [Mechanisms of psychological defense: genesis, functioning, diagnostics]. Retrieved from http://www.syntone-ufa.ru/library/books. (accessed 10 October 2019). 
activity is caused by excessive sensitivity. At this stage, the child is made aware of the rules and values and the principle of reality isintroduced into their life. The main value for the child is achieving comfort and avoiding discomfort. Using the rules for own benefit is a more progressive act than the need to contain impulses through external constraints. There is no holistic attitude to self at this stage; there is a sense of guilt integrated with discomfort, but its causes are projected on external objects or on the alienated part of self. Consequently, getting stuck at this stage causes hyperfunctions of the defense mechanisms, the desire to get maximum satisfaction at the expense of others with minimal stress.

Thus, the early pre-conventional stage remains a layer of primary experience in the subconscious and determines the starting positions of further non-linear dynamics of creative potential development. Fixation at the defense stage determines the perception of the world only in terms of person's own selfish needs and desires. The only way to get the desired is to control the environment and protect yourself. At the same time, it is important to understand that the creative opportunities potential in this case is aimed to getting the desired, which accompanies the sensory developmentand promptness of goals realization.

Signs of further development of the Ego in the conformism stage are revealed when the child begins to harmonize and relate their own comfort with the comfort of the outer space. The individual level of trust is an important prerequisite for this condition. In the case of being stuck on a destructive variant of the self-defense development stage, aggression, exploitation, deception, manipulation become typical for the person. The conformist follows the rules not because of fear of punishment, but to get approval from the targeting reference group, while group disapproval becomes a serious punishment. Group membership is a guarantee of safety. The regulation of creative potential is extrapolated and determined by an external force - an authoritative person or group of persons.

The stage of self-awareness is transitional from conformism to consciencestage according to $\mathrm{J}$. Loevinger. The development of 
awareness of the realEgothat is not quite in line with the ideal image or rules takes place. The content of the inner life at this and the previousstagescan be described by common stereotypical formulations. Self-awareness is a prerequisite for the further replacement of group standards and criteria by personal ones. In addition, if a conformist lives in a conceptually simple world where the word "no" means the same thing to everyone, at the level of selfawareness the person sees possible alternatives and exceptions to the rules, albeit so far in a stereotyped and generalized form. Also awareness of individual differences in character traits begins to emerge.

At the conscience stage, a radical complication of the mechanisms of self-regulation takes place. Few 13-14-year-olds are able to reach this stage. At this time the internalization of the rules iscompleted and there are basic elements of conscience: "long-term goals and ideals, differentiated self-criticism and a sense of responsibility"16. At this stage, the regulation of the personal creative potential is determined neither by the fear of punishment nor by a sense of conformism, but by a sense of responsibility as a guideline of individual behavior. The person who has reached this stage is not apt to feel guilty about breaking rules, but feels discomfort when doing harm to another person, even within the existing rules. A sense of responsibility for the own life and others develops; the concepts of obligations, privileges, rights and justice is formed. There is a desire for achievement on the basis of personal standards and criteria, acceptance of the importance of work, distinction between morality, traditions and fashion; the dichotomy of "right - wrong" and "good bad" is replaced by more complex and differentiated constructs. Main features of inner life at this stage are a variety and complexity of emotions, a shift of attention from the actions to their depthcauses, the ability to feel in the position of another person, expansion of temporal perspective and social contexts for understanding phenomena, events

16 Loevinger, J. (1976). Ego development: conceptions and theories. SanFrancisco: Jossey Bass Publishers (p. 20). 
and actions. Presumably, the conscience stage determines the positions for the internal regulation of creative potential.

At the individualistic stage, awareness of the identity feeling and problems of emotional interdependence of people appears replacing the moralism. Depth emotional reasons and problems of interpersonal relationships, and partly internal conflicts are considered. "Developed ability to accept paradoxes and contradictions leads to greater conceptual complexity, which is expressed in the awareness of the differences between the inner essence and external manifestations, between psychological and physiological reactions, between the process and the result", 17 .

At the autonomy stage the person has the ability to accept and manage internal conflict (between needs, obligations and both). "Perhaps autonomous personality has not more conflicts than others, but they have hardiness and other necessary qualities to accept a conflict and work with it instead of ignoring or projecting it to the outside world"18. The autonomous personality is capable of overcoming polar oppositions and perceiving the world in its volume and diversity. Conceptual complexity, high tolerance for uncertainty and making own mistakes are features of the autonomous personality. The autonomous personality respectsother people's need for autonomy, is free from the "dictatorship of conscience" in contrast to the previous stage, but is aware of the autonomy limitations and dialectic as well as emotional interdependence. A broad worldview, realism, objectivity, commitment to abstract ideals are typical for autonomous personality.

The last is the integration stage, which is the most difficult to describe because it rarely happens; it is distinguished from the autonomous stage by the consolidation of the identity sense. J. Loevinger compares this state with the well-known description of self-actualized

17 Loevinger, J. (1976) Ego development: conceptions and theories. SanFrancisco: Jossey Bass Publishers (p. 22-23).

18 Loevinger, J. (1976) Ego development: conceptions and theories. SanFrancisco: Jossey Bass Publishers (p. 23). 
personalities according to A. Maslow ${ }^{19}$. Leading expert in adult psychology and the theory of ego development S. Cook-Greuter ${ }^{20}$ studies the dynamics of different ways of making sense of reality or partial situations at the conventional and post-conventional stages.

The empirically sustainable description of the possible variant of creative potential development by J. Loevinger is heuristically valuable. It comprises stages from unconscious, undifferentiated symbiosis of the infant to the mature adult's conscious experience of commitment to the universe. The author goes in her studies from prerational to metarational, from pre-verbal phase to original postsymbolic wisdom when the person becomes aware of natural relations of all phenomena and the artificiality of borders, objects, traditional self-identification and becomes free. It is important that the researcher considers development through a dichotomy of stages determined by differentiation and integration; separation and participation; governance and connectedness; independence and unification; care and justice.

She points out that at conformist, conscience, autonomous, and integration stages of development the personality is balanced due to dominating integration and harmonious relationships with their newlyfound community that correspond to individual cognitive, emotional and cognitive needs. For the self-defense, self-awareness, individualistic stages, according to S. Cook-Greuter, differentiation and increased levels of tension, anxiety, uncertainty are typical. Consequently, these indicators testify to periods of self-organization and creative potential realization through a transgressive transition beyond the achieved stability.

The personality developments tages are of great heuristic value for this research as in its context they are related to the development of

${ }^{19}$ Maslow, A. (1997) Dal'nie predely chelovecheskoy psikhiki [The Farther Reaches of Human Nature]. St. Petersburg, Russia: Eurasia. (in Russian)

20 Cook-Greuter, S. (2005) Ego development: Nine levels of increasing embrace. Retrieved from http://newpossibilitiesassociates.com/uploads/9_levels_ of_increasing_embrace_update_1_07.pdf (accessed 15 October 2019). 
creative potential on the basis of productive internal regulation of personal dignity, realization freedom and conscious responsibility. At the conformism stage, according to S. Cook-Greuter, a linear worldview is a distinctive personal feature: objects are defined within specific limits, causality seems linear, and variables are independent. The person's mindset and priorities depend on the values, priorities, and status of the group to which the person belongs. The boundaries between Ego and others are tangled and blurred. On this basis, creativity development is studied in the process of adaptation as the basic need of the conformist stage is to be accepted.

At the self-awareness level, the creative potential is governed by high moral standards and conservative orientations for correctness in the fulfillment of their duties, and is manifested in compulsive behavior and perfectionism. It is connected with the power of the super-ego and exceedingly critical attitude to other people's thoughts, as pointed out by S. Cook-Greuter. Therefore, this is the level of dominating self-regulation and stability retention; that is why information that does not fit into standard schemes is denounced, rejected or discredited. Although complex decisions, better ideas, more sophisticated procedures are possible at the self-awareness stage, linear thinking prevents the person from identifying priorities of various opportunities and synthesizing them. Self-regulation of creative potential defines protection, ultra-rationality that involves imposing the own understanding of values on others and forming a pragmatic style of domination. The creative potential in the form of rational competent activity enables democratic interaction.

At the level of conscience, the creative potential of the individual is realized in the ability to go in with other people being loyal to their values. Cognition through feedback and introspection allows to understand own self, develops capability of selfimprovement. Formal operations and abstract rationality are used to find out the nature of things, including human nature. The conscience level of creative potential development is manifested in the willingness to realize the idea of "goodness for all". The personality is aware of the potential evolution process, based on the analysis of self and 
others, self-knowledge and continuous improvement. Guilt is one of the main emotions, extremely strong self-criticism. Creativity development is affected by excessive critical, neurotic selfpunishment. Conscientiousness is manifested in the self-regulation of life, in particular responsibility, honesty, rational decisions and acts to improve the world. Rationality, progressivism, positivism and reductionism are distinctive features of creativity.

Analyzing the individualistic level of the postconventional stage, S. Cook-Greuter notes that the perception of reality is characterized by a systematic nature that allows the individual to acquire a more holistic state involving feelings and contexts of the life activity process. The reassessment of previously uncritically perceived things takes place, including role-identified identities and selfredefining. It happens because the priority of a unique creative potential, independent of society and focused on cognition of the inner world and its special meanings, is recognized. Distancing from the world to acquire own identity, the person often brings creativity into the activity, a new vision of particular problems, or inspires others with their enthusiasm to follow their interests. Linear, intellectual logic gives way to a holistic understanding of phenomena and processes. It becomes possible due to trust - a quality that opens the personality for development. Convincing, justifications, analysis are inferior in value to subjective experience.

Personality concentrates their own creative potential on processes, relationships and non-linear influences of different variables. The existential sense of difference and peculiarity of every moment of being is obvious. Intrinsic contradictions caused by processes of differentiation, actualizing the conscious desire to integrate different parts of creative potential,are typical. At the same time, the creative orientation of the person to the cognition of their feelings and motivation develops an awareness of the imperfection or limitations of self-regulatory processes along with the use of defense mechanisms. As it was stated above, they are considered to be self-deception and distort social and perceptual experience. On the other hand, the ability to reflection increases. The creative potential at the individualistic stage is 
characterized by energetic self-expression and carelessness, spontaneity and ability to live according to their own unique features, free from the limitations of society. However, unpredictability and freedom sometimes makes interaction with others difficult.

In the autonomy stage, personal creative potential acquires the ability to integrate its parts. Own interpretation of the experience gets more meaning. At the autonomous stage, the creative potential of the individual is realized consciously, life activity is meaningfulness due to the self-determination and self-actualization in the dynamic context. At this stage, the person is able to consciously reconcile their internal development processes. Due to the awareness of the shadow aspects of the personal creative potential, a qualitatively new stage of integration becomes available. Responsibility regulates conflicting needs, experience is perceivedwith immediacy, creative potential is not used fordefense, those are indicators of tolerance and spontaneity.

The personality needs the presence of others to fully realize their creative potential: dynamic and close exchange with others leads to deep self-cognition and reaching the wisdom. Interaction with others is essential,it is experienced with awe and awareness of responsibility for them. At the autonomy stage, the regulation of personality functions through conscious defenses: altruism, humor and forethought. Creative potential is focused on providing selfactualization and self-realization.

At the second level of the post-conventional stage, S. CookGreuter distinguishes two periods on the basis of newly formed structures and understanding of different layers of symbolic abstractions: construct-conscious and integrated. The researcher notes that ability to make fundamental assumptions about human nature and the need to create order out of chaos are existential problems of personality. So, creativity involves awareness of the development model, visibility of the own development thatcomprises wide range of experience and thoughts. The personality is aware of the used intellectual defense tendencies for self-preservation.

In the construct-conscious period, creative potential is directed to a dynamic and diverse understanding of human nature, difficulties 
of human interaction and can be realized through the need to create theories and concepts. Processes of self-awareness and reasoning become more differentiated; access to intuition, bodily states, feelings, dreams, archaic and transpersonal experiences widens. The ability to acquire knowledge from irrational sources of information is increasing in the post-conventional development period.

It is important that the regular practising of focusing on the own inner world and observing mental processes often leads to spontaneous manifestation of ways of being when knowledge and cognition are instantly merged, and the feeling of Ego dissolves. A. Maslow ${ }^{21}$ defines such states of higher creative experience of grace as peak experiences.Creative potential is free from constant Ego control. In the construct-conscious period, the person experiences changes and evolution due to the sensitivity and ability to understand others in terms of development.

The integration stage of development is determined by a completely different way of perceiving human existence and consciousness. S. Cook-Greuter notes that the new paradigm has a universal or cosmic perspective. The personality considers themselves and others as a part of humanity, originating from the creative foundation with an evolutionary purpose. The two poles of the Pascal paradox integrate: the person experiences the belonging sense and the sense of isolation and uniqueness without tension as a change in the perception of the opportunities variety of being. Birth, growth and death, joy and pain are understandable natural events, change modes in the life flow. Conscious or rational awareness is no longer perceived as a limitation, but as one of the dominating phenomena that depends on the present moment. Internalized transpersonal or interpersonal morality is a feature of the integration period. Internal conflicts and conflicting external needs are parts of being that require not solution but testifying. Spontaneity, independence and impersonal attitude allow the person to act directly and powerfully in case of need. Reality

${ }^{21}$ Maslow, A. (1997) Dal'nie predely chelovecheskoy psikhiki [The Farther Reaches of Human Nature]. St. Petersburg, Russia: Eurasia. (inRussian) 
can provoke deep emotional experiences as an undifferentiated phenomenological continuum or as a creative basis for integrated consciousness.

The sense of interconnection with all living beings in their struggle for survival and for recognizing the sense of their existence dominates at the integration stage. Typical features of the personality are tolerance, compassion and connection with life. Absolute openness makes it possible to set the person up for the truth, kindness and beauty, visionary experiences, understanding wholeness of things. High level of trust to the worldallows to process information and experience without conscious willful attention to it. Creativity is realized for everybody's benefit and on the basis of responsibility for sense creating. Activity and thinking are just in existence modes; they are not more valuable than feelings, existence or non-existence.

The integration stage of creative potential development is expressed in a balanced, integrated sense of independence, in particular separation. The person feels as a part of the constant universe evolution in all aspects of the cycle of creation, destruction and re-creation.

The meaning of development is not in the desire and ability to reach quantitative and qualitative increase or decrease of meaningful indicators, but in the formation of new fundamental backgrounds of the structure where the relationships between its elements are reestablished.

The theory of Ego development allows to understand the ontogeny of creative potential from the level of localization of the creative resource in the unconscious layers at the stage of symbiotic unity to the higher level of its integration with the world at the postconventional stage.

\section{CONCLUSIONS}

The research is based on modern scientific and philosophical positions and interprets development as a special kind of internal change which is associated not only with the emergence of new elements, but with changes in the structure and relationships between its elements. In 
most theories, human development is presented as a spiral movement, possible in all directions. The creative potential goes upward under the influence of spiritual values due to the need for self-actualization and personal dignity. "Vertical" development implies progressive transformations in the structure of the personal creative potential, person's life activity and environment. Horizontal movement and change are explained as expansion, movement within the same stage (development of skills, accumulation of knowledge). The creative potential provides adaptation to the conditions of the actual space and the use of its resources for life support. Downward movement causes temporary or permanent regression, mostly caused by fixation on the unsatisfied need at previous development stages. In most cases the creative potential of adults is represented in horizontal extension. People acquire new skills, techniques, ways of organizing knowledge, but the stage of their personal development, mental world model, dignity status, level of development and realization of creative potential remain unchanged.

In this research personal creative potential is interpreted as the process of transition immense potentiality into reality, accompanied by transgression and movement to a higher stage. To explicate personal creative potentialdevelopment the model of comparative theory of ego development by J. Loevinger was integrated with the concept of Ego development stages by S. Cook-Greuter. The study was focused on the revealing possibilities of internal regulation of the personal creative potential by the conscious responsibility level. Thus, the responsibility dynamics was traced at the conventional stage starting from its diffuse form at the conformismlevel, critical intensification to the sense of guilt at the conscience level, and gradual improvement at the postconventional stage due to the trust to the self and to the world.

\section{SUMMARY}

The issue of personal creative potential development is studied. In the anthropocentric paradigm, the current status of the "creative potential"phenomenon is relevant. The latent character and nonlinear determination of its development stipulates the nesessity for scientific and psychological analysis of the Ego development in ontogeny. 
Development is considered as a special kind of internal change related to the emergence of new elements, as well as changes in the structure and specificity of the relationships between the elements.

The development of the creative potential of the individual is explicated on the basis of the model of Ego development. The logic of its development is related to the content and features of the Ego development stages. Possibilities of internal regulation of the personal creative potential by the conscious responsibility level are revealed. The dynamics of responsibility is analyzed starting from its diffuse form at the conformism stage to the trust level to the self and to the worldat the post-conventional stage.

\section{REFERENCES}

1. Heidegger, M. (2003) Bytie $i$ vremya [Being and time]. Kharkov, Ukraine: Folio. (in Russian)

2. Shchedrovitskyi, H. (1995) Izbrannye Trudy [Selected works]. Moscow, Russia: Shkola kulturnoi politiki. (in Russian).

3. Davydov, V. (1996) Teoriya razvivayushchego obucheniya [Theory of developing education]. Moscow, Russia: INTOR. (in Russian)

4. Vygotsky, L. (1982) Sochineniya [The collected works]. Moscow, Russia: Pedagogika. (in Russian).

5. Elkonin, D. (1994) Vvedenie $v$ psikhologiyu razvitiya [Introduction to the developmental psychology]. Moscow, Russia: Trivola. (in Russian)

6. Slobodchikov, V. (1991) Kategoriya vozrasta v psikhologii $i$ pedagogike razvitiya. [Category of age in psychology and pedagogy of development]. Voprosy psikhologii [Psychology Issues], no. 2. Pp. 37-49.

7. Elkonin, D. (1995) Psikhicheskoe razvitie $v$ detskikh vozrastakh [Psychic development in child age]. Moscow, Russia: Institut prakticheskoi psihologii. (in Russian)

8. Piaget, J. (1994) Izbrannye psikhologicheskie trudy [Selected works in psychology]. Moscow, Russia: Mezhdunarodnaia pedagogicheskaia academia. (in Russian) 
9. Dambrowski, K. (1977) Multilevelness and Positive Disintegration. New York : Dabor science.

10. Loevinger, J. (1976) Ego development: conceptions and theories. SanFrancisco: JosseyBassPublishers.

11. Freud, A. (1993) Psikhologiya "Ya" $i$ zashchitnye mekhanizmy [The Ego and the mechanisms of defense]. Moscow, Russia: Prosveshchenie. (in Russian)

12. Romanova, E. (1996) Mekhanizmy psikhologicheskoy zashchity: genezis, funktsionirovanie, diagnostika [Mechanisms of psychological defense: genesis, functioning, diagnostics]. Retrieved from http://www.syntone-ufa.ru/library/books. (accessed 10 October 2019).

13. Maslow, A. (1997) Dal'nie predely chelovecheskoy psikhiki [The Farther Reaches of Human Nature]. St. Petersburg, Russia: Eurasia. (in Russian)

14. Cook-Greuter, S. (2005) Ego development: Nine levels of increasing embrace. Retrieved from http://newpossibilitiesassociates.com/ uploads/9_levels_of_increasing_embrace_update_1_07.pdf (accessed 15 October 2019).

15. Konovalchuk, V. I. (2016) Tvorcha osobystistj u prostori osvity [Creative personality in the education space]. Umanj : FOP Zhovtyj O. O. (in Ukrainian)

Information about the author:

Valentyna Afanasenko, Doctor of Philosophical Sciences, Candidate of Psychological Sciences (PhD), Chief of the Psychology Department, Cherkasy Regional Institute for Postgraduate Education of Teachers 38, Bydhoshchska str., Cherkasy, 18000, Ukraine ORCID ID: orcid.org /0000-0002-9219-7087 
DOI https://doi.org/10.36059/978-966-397-161-2/26-48

\section{METHODOLOGIKAL COMPETENCE OF PRE-SCHOOL TEACHERS IN THE PROFESSIONAL PEDAGOGICAL COMPETENCE STRUCTURE}

\section{Liudmyla Aleksieienko-Lemovska}

\section{INTRODUCTION}

Changes taking place in the modern education system are determined by the need for increased teachers' professional development and professionalism, their professional competence. The competence-based education model arises from education modernization aimed at preparing the individual for life, identity formation, as well as general preparation for the fulfillment of the whole range of social functions. As a result, there is a shift in the assessment of educational outcomes from the concepts of "education", "good breeding", "preparedness" to the ideas of "competence" and "competency".

One of the most important components of professional and pedagogical competence is methodological competence covering the field of knowledge and skill set formation methods and determining the dependence of this competence development on the quality of professional activity.

In the current conditions of education development in Ukraine, there is a reassessment of education professionals' methodological work. New models of methodological assistance that meet the demands of modern society are gradually being developed. New directions and forms are taking place, the content is qualitatively changing, and there is a tendency of this activity being variable and multilevel depending on educational institutions' requests and preparedness. In general, the teacher's methodological training is the process and result of mastering the system of methodological knowledge, skills and abilities and preparedness for their implementation in professional activity. 
The organization of methodological activities is an important factor in preschool teachers' professional development and is one of the ways of education reforming.

At the heart of methodological activities, there are scientific achievements and pedagogical experience. It is a complex system of interrelated activities aimed at improving the preschool teacher and the whole pedagogical staff's qualification and professional skills. Methodological activity also covers independent organization and assessment requiring the teacher's personal commitment and creativity as well as the definition of the main objectives of this activity type organization in preschool institutions.

Methodological competence determines the ability and readiness for purposeful, systematic activity in performing professional tasks and solving problems. Independently chosen learned thinking and working methods or strategies are applied and improved for solving job-related problems and tasks.

The need to develop preschool teachers' methodological competence in the system of continuing education is brought about by new trends in the information society, the associated accumulation of scientific knowledge and the need to find effective mechanisms for its transfer and use.

\section{The essence and specific aspects of pre-school teachers' methodological competence in the professional pedagogical competence structure}

The competence-based education model in defining educational goals and its content is not a completely new phenomenon. The competence-based approach as a subject of scientific research in the higher education system was in the scope of interests of the following scholars: N. M. Bibik, O. V. Gluzman, O. I. Lokshyna, O. V. Ovcharuk, O. I. Pometun, O. V. Savchenko and others. N. M. Bibik emphasizes the necessity of turning the focus from a learning process to learning outcomes in terms of the activity approach ensuring the graduate's ability to respond to new demands of the labor market as well as the availability of adequate potential for practical solutions to real-life 
problems ${ }^{1}$. O. V. Gluzman claims the competence-based approach to consist in shifting the emphasis from the accumulation of normative knowledge, skills, and abilities to the cultivation and development in students of the ability to act pragmatically, to apply individual techniques and experience of successful activity in job-related situations and social practices ${ }^{2}$. According to O. V. Savchenko, the general idea behind the competence-based approach is competence-oriented education aimed at the complex acquisition of knowledge and practical activity methods through which a person successfully realizes their potential in different life spheres ${ }^{3}$.

The competence-based education model is being developed by such researchers V. A. Adolf, T. N. Gushchyna, N. V. Kuzmina, L. N. Mitina, V. A. Slastonin, A. V. Khutorskyi and others. Scientists propose different interpretations of the competence-based approach. A. V. Khutorskyi introduces the concept of education competence implying the set of sense bearing orientations, knowledge, skills and experience concerning real-life objects ${ }^{4}$. N. V. Kuzmina in the context of pedagogical activity considers methodological competence as one of the basic elements of teachers' professional competence which includes proficiency in formation methods of students' knowledge and skills. Competent teachers are equipped with a good teaching

1 Bibik N. M., Vashchenko L. S., Lokshyna O. I., Ovcharuk O. V. (red.) (2004) Kompetentnisnyi pidkhid $u$ suchasnii osviti: svitovyi dosvid ta ukrainski perspektyvy : Biblioteka $z$ osvitnoi polityky [Competence approach in modern education: international experience and Ukrainian prospects: library of educational policy], K. : K.I.S. (in Ukrainian)

2 Hluzman O. V. (2009) Bazovi kompetentnosti: sutnist ta znachennia v zhyttievomu uspikhu osobystosti [Core competence: the nature and value of individual success in life]. Pedahohika i psykholohiia, no. 2, pp. 51-60.

3 Savchenko O. P. (2010) Kompetentnisnyi pidkhid u suchasnii vyshchii shkoli [Competency approach in modern universities]. Pedahohika i nauka: istoriia, teoriia, praktyka, tendentsii rozvytku, no. 3, pp. 16-23.

Khutorskoi A. V. (2003) Kliuchevye kompetentsyy kak komponent lychnostno-oryentyrovannoi paradyhmы obrazovanyia [Key competences as a component of personality-oriented educational paradigm]. Narodnoe obrazovanye, no. 2, pp. 58-64. 
methodology, clearly define their attitude to different methodological systems, and have their individual methodology style ${ }^{5}$.

In the conditions of the competence-based approach implementation, the problem of improving teachers' professional competence comes to the fore. Pedagogical personnel's basic qualification characteristics are determined according to the staffing requirements. A preschool teacher's qualification should reflect universal cultural, general professional and professional competence.

In psychological and pedagogical sources there are several approaches to the definition of the professional competence phenomenon, such as pragmatic and functional, axiological, universal, personal and pragmatic. Within the pragmatic and functional approach, competence is described as the unity of theoretical and practical preparedness for teaching activity, the fulfillment of professional functions in which basic parameters are set by the functional structure of teaching activity. The axiological approach enables to consider professional competence as an educational value implying the introduction of a person into the universal cultural world of values where an individual realizes him-or herself as a specialist and a professional. According to the universal approach, professional competence is connected, on the one hand, with a specialist's basic qualification, on the other - it allows individuals to orient themselves in a wide range of issues not limited to specialization. It provides individuals' social and professional mobility, openness to changes and creative pursuit, the ability to fulfill their potential, self-creation, and self-education. Within the framework of the personal and pragmatic approach, the teacher's personality and activity as a person in the profession are considered through the specifics of teaching involving interaction with and influence on other people.

The competence-based model attempts to enrich an educational process with personal sense. It is about the education emphasis on

${ }^{5}$ Kuzmyna N. V. (1990) Professyonalyzm lychnosty prepodavatelia y mastera proyzvodstvennoho obuchenyia [The professionalism of the teacher's personality and the master of industrial training], M.: Vysshaia shkola. (in Russian) 
education outcomes. The result is not the amount of information learned, but a person's ability to act in problematic situations. It is possible to distinguish the following principles of this model: 1) the principle of knowledge subordination to skills and practical needs; 2) adaptation of educational objectives to preparation for life; 3) focus on lifelong and self-education. Since the teaching profession is both transformative and managerial, the concept of the teacher's professional competence implies the unity of their theoretical and practical preparedness to carry out pedagogical activity characterizing their professionalism. In this regard, professional competence is determined by the level of professional readiness for work ${ }^{6}$.

In pedagogical literature, there is no single point of view on the essence of the "competency" and "competence" concepts. Competency is personal and interpersonal qualities, abilities, skills and knowledge expressed in different forms and job-related or social life situations.

Nowadays, the "competence" concept has been expanded to include the personal qualities of an individual. Competence means that a person has relevant competency, including personal attitude to it and the object of activity. O. V. Gluzman claims competence to cover not only cognitive and operational-technological components, but also motivational, ethical, social, and behavioral ones including learning outcomes, a system of value orientations. Thus, competences are formed not only during training but also under the influence of family, friends, work, politics, religion, etc. The study of the competence based approach problems in general education was conducted by A. V. Khutorskyi, who, defining the concept of educational competences, proposes their three-level hierarchy: 1) key competences - related to the general (meta-subject) content of education; 2) general subject competences - referring to a certain range of subjects and education; 3) subject competences - partial in

${ }^{6}$ Edwards R., Nicoll K. (2006) Expertise, competence and reflection in the rhetoric of professional development. British Educational Research Journal, no. 32, pp. 115-131. 
relation to the two previous competence levels characterized by a specific description and the possibility to be cultivated within the academic subjects.

Viewed in this way, there are seven key educational competences: axiological, cultural, learning and cognitive, information, communicative, social-labor and self-improvement. They do not conflict with the core competences singled out by the Council of Europe and can be implemented in the practice of pre-school education.

The success of pedagogical activity depends on each teacher's ability and skills to mobilize their efforts for systematic mental work, rationally build their activity, manage their emotional and psychological state, unlock their potential, and be creative.

The following is the structure of key competences in education:

- educational competence lies in the organization of a learning process and choosing one's own education trajectory, solving the education and self-education problem, the analysis and implementation of educational experience, taking responsibility for the obtained education;

- research competence consists in obtaining and processing information, reference to different sources and their use, organizing expert consultations, preparation and discussion of different resource types for different audiences, using regulatory documents and their systematization in independently organized activity;

- social and interpersonal competence implies a critical review of some social development aspect, determination of the connection between contemporary and past events, awareness of the importance of political and economic contexts, educational and professional situations, assessment of social events related to health, consumption and the environment, art work and literature understanding;

- communicative competence involves listening and taking into account other peoples' views; speech perception and ability to speak, read and write in several languages; to speak in public, to discuss.

A necessary component of an individual's professionalism is professional competence. Modern professional competence 
approaches and its interpretations are quite different. The definitions of professional competence as "in-depth knowledge", "the state of adequate task performance", "the ability to fulfill a task in a timely manner" are prevailing. In order to gain professionalism, it is required to have appropriate abilities, desires and personality traits, a willingness to constantly learn and improve one's skills ${ }^{7}$.

The teacher's professional competence is the ability to solve professional problems, tasks in professional activity conditions; the amount of knowledge and skills that determine work effectiveness and efficiency. It is a combination of personal and professional qualities. This competence is determined by a motivated desire for continuing education and self-improvement, a creative and responsible attitude to the occupation. The teacher's competence as a professional is manifested in knowledge, education, and authority in the pedagogical field.

Professional and pedagogical competence includes the set of professional and personal qualities necessary for successful pedagogical activities. The development of professional competence is the development of creative individuality, openness to pedagogical innovation, and the ability to adapt to the changing pedagogical environment.

In accordance with the definition of the "professional competence" concept, it is proposed to carry out the assessment of the level of pedagogical staff's professional competence using three criteria: knowledge of modern pedagogical technologies and their application in professional activity; willingness to solve professional objective tasks; the ability to control its activities in accordance with the rules and regulations.

Different authors have developed different models and variants of the component structure of the teacher's professional competence. Thus, within the professional competence, N. V. Kuzmina

${ }^{7}$ Sharmahd N., Peeters J., Bushati M. (2018) Towards continuous professional development: Experiencing group reflection to analyse practice. European Journal of Education, no. 53 (1), pp. 58-65. 
distinguishes its five elements: special competence in the discipline; methodological competence in the methods of forming knowledge, skills, and abilities; psychological and pedagogical competence in the field of teaching; differential psychological competence in the field of motives, ability, determination; autopsychological competence. V. A. Adolf argues professional competence to consist of a personal attitude to future professional activity. Professional competence is also defined as a holistic multilevel and multifunctional system of interrelated competencies, methodological one being its part. In the teacher's professional competence structure, the scientist includes the following components: theoretical and methodological, cultural, subject, psychological and pedagogical, technological. Professional competence is determined by the level of one's own professional education, individual experience and ability, as well as a motivated desire for continuing self-education and self-improvement, creative and responsible attitude to the occupation ${ }^{8}$. In V. A. Slastonin's terms, professional competence is the unity of theoretical and practical preparedness to carry out pedagogical activities where the quality of the pedagogical problem solving is determined by the teacher's professional competence level ${ }^{9}$.

In the scientific literature, the terms pedagogical competence (L. N. Mitina) and professional competence (V. A. Slastonin) are equally used. Many modern researchers also distinguish methodological competence in the professional and pedagogical competence structure.

Methodological competence is viewed by researchers as the ability to recognize and solve methodological problems and tasks arising during pedagogical activity. T. N. Gushchina defines methodological competence as a set of methodological knowledge,

${ }^{8}$ Adolf V. A. (2005) Obnovlenye protsessa podhotovky pedahohov na osnove modelyrovanyia professyonalnoi deiatelnosty [Updating of process of teachers training on the basis of modeling of professional activity]. Krasnoiarsk. (in Russian)

Slastenyn V. A., Ysaev Y. F., Shyianov E. N. (2002) Pedahohyka [Pedagogy]. Ucheb. posobye dlia stud. vyssh. ped. ucheb. zavedenyi. M.: Akademyia. (in Russian) 
operational and methodological as well as psychological and pedagogical skills that are formed in the process of teachers' professional training, together with technological readiness to use modern educational information and communication technology, methods and techniques in an educational process adapting them to different pedagogical situations ${ }^{10}$. Methodological competence is formed in the process of teachers' professional training and, as a result, it shapes their value orientations, as well as readiness for creative self-fulfillment in pedagogical activity. Such competence involves the capacity for methodological self-analysis, the ability to critically evaluate and review the quality of learning activities, to analyze used techniques and exercises in terms of their effectiveness.

Thus, the teacher's professional competence includes subject (special), psychological and pedagogical, differentiated pedagogical, methodological, and reflexive components.

Subject (special) competence includes knowledge of the discipline; orientation in modern research; mastery of teaching methods for delivering disciplines (the ability to orient oneself in the variety of different teaching methods and techniques); use of modern teaching technologies. Psychological and pedagogical competence is considered as the availability of basic psychological and pedagogical knowledge and skills that determine the success in the fulfillment of a wide range of educational objectives; ability to identify children's individual capacity and to organize an educational process accordingly; ability to identify gaps in children's knowledge and skills, to realize individual ways of working out how to bridge such gaps; ability to establish pedagogically appropriate relationships with children, colleagues, and parents; ability to create a favorable microclimate for teaching staff. Differentiated pedagogical

10 Hushchyna T. N. (2001) Formyrovanye metodycheskoi kompetentnosty pedahohycheskykh rabotnykov dopolnytelnoho obrazovanyia detei $v$ protsesse povyshenyia kvalyfykatsyy [Formation of methodical competence of teachers of the institute of additional education of children in the process of professional development]. Yaroslavl. (in Russian) 
competence includes the ability to identify children's individual capacity, attitudes and orientations, to determine and take into account people's emotional state, the ability to build relationships with leaders, colleagues, children, and parents). Pedagogical activity reflection or autopsychological competence includes the ability to be aware of the level of one's own activity, abilities, the knowledge of professional improvement methods, the ability to identify the causes of weak points in performed activity, and the desire to perfect oneself.

Methodological competence is considered as an integral multilevel professionally significant characteristic of the teacher's personality and activity based on the effective professional experience; methodological and pedagogical activity as a whole implying the optimal combination of professional pedagogical activity methods. It reflects the systemic level of functioning of methodical, methodological and research knowledge, skills, experience, motivation, abilities and readiness for creative self-fulfillment in scientific-methodological and pedagogical activity as a whole involving the optimal combination of professional pedagogical activity methods ${ }^{11}$. The teacher's professional competence is formed in higher education institutions, but its development can take place only in the course of pedagogical activity. In general, preschool teachers' methodical training is the process and result of mastering the system of methodological knowledge, skills and readiness for their implementation in professional activity.

\section{Organization of methodological activities as a factor of preschool teachers' professional development}

Methodological competence development involves mastering practical activity methods aimed at meeting an individual's needs of a high priority for the given professional group. The increased level

11 Alekseenko-Lemovska L. V. (2015) Theoretical aspects of methodical competence of teachers of preschool educational institutions. Szkola-Zavod-Praca. Universytetu Kazemiera Wielkiego. Bydgoszcz, no. 10, pp. 11-19. 
of needs as a result of professiogenesis, that is, the teacher's professional becoming and development, brings about the improvement of existing and the development of new innovative activity methods and, accordingly, an increase in the methodological competence level.

Methodical competence is considered as a special competence implementing the basic and key competences regarding the specificity of professional pedagogical activity. Competent teacher has a good teaching methodology, clearly defines his attitude to different methodological systems, and has his own individual style of activity in the methodology.

The improvement of teachers' scientific and methodological competence in professional activity was in the scope of A. M. Bogush's papers, L. M. Mitin and N. M. Murovan investigate the problem of teachers' methodological training. Methodical activity organization issues are discussed by K. Yu. Bila, L. I. Illenko, K. L. Krutii, V. A. Slastonin and others. K. Yu. Bila proposes the following goals of methodical work in the preschool education institution: the development of the most rational methods and techniques for teaching, upbringing and development of preschool children; raising the level of the teacher's general didactic and methodological readiness to organize and conduct the educational process; experience exchange between the teaching staff members ${ }^{12}$. L. I. Ilienko defines the principles of methodical work organization, which contribute to the achievement of its key goal - the professional activity improvement ${ }^{13}$. K. L. Krutii reveals the main task of methodical work - the creation of such educational space in the

12 Belaia K. Iu. (2007) Metodycheskaia rabota v DOU: Analyz, planyrovanye, formy y metody: metodycheskoe posobye [Methodical work in a preschool educational institution: Analysis, planning, forms and methods: a methodical manual]. Metodycheskoe posobye. M.: TTs Sfera. (in Russian)

${ }^{13}$ Ylenko L. Y. (2003) Teoryia y praktyka upravlenyia metodycheskoi rabotoi $v$ obrazovatelnykh uchrezhdenyiakh [Theory and practice of methodological work management in educational institutions]. M.: ARKTY. (in Russian) 
institution, where the creative potential of the teaching staff and every subject in particular would be fully implemented ${ }^{14}$.

Methodological work in a preschool institution is a systematic collective and individual activity of pedagogical staff aimed at increasing its scientific-theoretical, cultural level as well as the level of psychological-pedagogical training and professional skills. The purpose of organizing methodological work in the pre-school institution is to create optimal conditions for continuing improvement of the level of educational process participants' general and educational culture.

According to K. L. Krutii, the main task of methodological work is to create such an educational environment in an institution where the creative potential of the teaching staff and every subject, in particular, would be fully realized.

The review of methodological work with staff, educational process scientific and methodological support, and the creation of a new development environment is one of the important tasks of the preschool institution's innovative development. That is why the general goal of methodological work lies in education quality assurance and continuing education system development for an educational institution teaching staff. It is determined by methodological work principles among which the leading ones are the principles of education democratization and humanization.

The main goal is to assist preschool teachers and the whole teaching staff in their professional competence upgrading and development to achieve good results in their teaching activities.

To achieve this goal, it is necessary to identify the initial level of teachers' professional training, and then formulate a goal, plan and organize methodological work with them.

14 Krutii K. L. (2003) Innovatsiina diialnist $v$ suchasnomu doshkilnomu navchalnomu zakladi: metodychnyi aspekt [Innovative activity in a modern preschool educational institution: methodical aspect]. Zaporizhzhia: TOV «LIPS» LTD. (in Ukrainian) 
Teaching activities are collaborative, not individual. In pedagogical activity communication becomes functional and professionally significant; it serves as an instrument of influence on the child's personality. Pedagogical communication is a holistic system of social and psychological interaction between a teacher and children, which includes the exchange of information, educational influence and the organization of relationships through communicative means.

The task of pedagogical activity is to create conditions for an individual's harmonious development. It is achieved by the organization of the development environment, the management of various activities and the construction of proper interaction with the child. In general terms, methodological work objectives are formulated by V. A. Slastonin: formation of innovative orientation in teaching staff's activity which is manifested in the systematic study, generalization and spreading of pedagogical experience, in the work on the implementation of pedagogical science achievements; raising the level of teachers' theoretical and psychological training; inquiries into new educational programs, curricula, state educational standards; investigation of new normative documents, guidance materials; providing advisory assistance to teachers in self-education.

The following are the principles of methodological work organization contributing to the achievement of its key goal improving professional activity (according to L. I. Illienko):

- relevance, unity of theory and practice involving the practical implementation of the law "On education", taking into account modern societal demands for education, orientation to the child's social significance in today's difficult living conditions as well as pressing challenges for specific teaching staff;

- scientific character aimed at bringing the system of teachers' training to the conformity with modern scientific achievements in various fields;

- systematic character and complexity in terms of which methodological work is considered as an integral system which depends on the unity of objectives, content, purpose, forms and 
methods of working with educators as well as the unity and interconnection of all parties and directions of teachers' professional development;

- goal orientation, consistency, succession, continuity, a mass character, and collectivity involving the methodological work transformation into a part of the continuing education system, full teachers engagement into various forms of methodological work throughout the academic year;

- creation of favorable working conditions - moral, psychological, sanitary, the availability of free time for the teacher's creative activity;

- efficiency, flexibility, mobility and an individual approach requiring methodologists to be able to quickly receive and transfer educational information, taking into account the educational institution educators' individual characteristics;

- creativity implying the creative nature of methodological work, the creation of a methodological work system in a preschool institution;

- continuing teachers' self-education, qualified assistance provision both in theoretical and in practical matters; improving teaching effectiveness.

A special place in the methodological work of the pre-school institution is given to the principle of providing an individualized differentiated approach to educators' pedagogical activity. In modern conditions, methodological work with staff should be built on a diagnostic basis, taking into account each teacher's needs.

The implementation of methodological work, which is defined as individually-oriented, allows developing teaching staff's initiative and creativity by involving everyone in an active professional activity.

When formulating the methodological work objectives of a preschool institution, a group of its interrelated functions should be singled out.

The functions of methodological work from the standpoint of education system hierarchical levels (A. M. Moiseieva and 
O. M. Masovyi) are defined as: the functions of methodological work in relation to advanced pedagogical experience, pedagogical science in general - to the national education system; the functions of methodological work in relation to the educational institution's pedagogical staff; functions of methodological work in relation to a particular teacher.

P. I. Tretiakov considers the functions of methodological work through managerial tasks: information and analytical, motivational and target-oriented, planning and prognostic, organizational and executive, control and evaluation, regulatory and corrective.

The content of the methodological work is also considered in terms of the main functions:

1) the functions of methodological work in relation to the educational institution's pedagogical staff:

- improving pedagogical activity;

- updating educational process software;

- pedagogical staff's introduction to pedagogical science and practice achievements;

- implementation of advanced pedagogical experience in preschool institutions.

2) the functions of methodological work in relation to a particular teacher:

- research on the level of preschool teachers' professional training, identification of teachers' problems and professional needs;

- organization of work on boosting teachers' professional growth: enhancement of social and psychological culture; improvement of special skills; knowledge of human and national culture.

Methodological work is defined as the process of teachers' professionalism development which should be considered through internal and external factors. External factors are socio-cultural environment and the education system where it is necessary to take into account the current educational situation. Internal factors include the following: teachers' self-cultivation, self-education and self-development in accordance with the requirements of state standards. 
There are several types of methodological activities: research, experimental, and corrective (according to S. Zh. Honcharova). The research type provides innovative processes, the experimental type ensures the transition from the development mode to the mode of functioning, the correction one facilitates functioning.

Priority methodological work directions as well-organized activity methods on the achievement of goals are methodological, scientific-methodological, didactic educational process support as well as the creation of optimal conditions for interaction of all participants in the educational process.

The most widespread is the following classification of methods:

1. according to the ways of information presentation: verbal (oral, printed), visual (illustration and demonstration methods), practical (workshops, trainings);

2. according to the degree of independence in knowledge acquisition: reproductive, partially-searching, searching, research;

3 . according to the way of knowledge acquisition: explanatoryillustrative, programmed, heuristic, problem- and model- based.

In the first case, methods similar to those used in working with preschoolers are more commonly used.

However, in order to organize activities to improve preschool teachers' professional competence, the most appropriate ones are the methods given in the second and third groups. At the same time, new, nontraditional, interactive methods of work with the pre-school institutions' pedagogical staff are being increasingly applied - they enable to simultaneously solve learning and cognitive, communicative and orientation tasks due to the opportunity to organize educational communicative environment facilitating the professional knowledge and skill acquisition.

The competence-based approach allows to consider the development of preschool teachers' methodological competence as a gradual process of acquiring knowledge, practical skills of organizing methodological work in a preschool institution and the experience of emotional and value-based attitude to the teaching subject and 
methods that meet preschoolers' needs and the post-industrial society's requirements to the teacher's personality ${ }^{15}$.

The creation of effective conditions for preschool teachers' professional development and children's continuing holistic development, the quality of interaction with the family determine the main methodological work objectives:

1. Teaching staff's training and development, as well as its skill enhancement management.

2. Finding out, research, generalization and spreading of the best teachers' pedagogical experience.

3. Methodological support development for its implementation in an educational process.

2. Activity coordination between preschool institutions and the family aimed at children's continuing holistic development.

3. Coordination of preschool institutions' actions with other institutions to ensure children's development as well as the institution's progress in general.

4. Analysis of performance quality in order to create the conditions for ensuring positive changes in preschoolers' personality development through improving teachers' professional competence.

Due to the fact that in the structure of the basic preschool education program there identified the main directions of children's development (physical, cognitive-speech, social and personal, artistic and aesthetic), preschool education institutions generate demand for specialists capable of assisting educators and parents in their implementation, taking into account age, children's individual characteristics, contributing to a comprehensive approach to the development of educational sectors available to preschoolers.

15 Alekseenko-Lemovska L. V. (2016) Scientific approaches to the problems of methodical competence of teachers in pre-school educational institutions. Nauka $i$ studia. Przemysl. Poland. Pedagogiczne nauki psichologia i socjologia, no. 24-4 (158), pp. 95-100. 
All professional competence structural components are aimed at the preschool teacher's practical activity, in particular, the capacity for solving specific pedagogical situations.

The content of methodological work in the preschool educational institutions is determined in accordance with the specific goals and objectives. Also, the results of the educational process, qualifications of teachers are taken into account.

Implementation of methodological work allows developing the initiative and creativity of the teaching staff by involving each member in active professional activity.

The work is conducted in the following areas: educational educators' professional development in theoretical aspects and mastering modern methods of interaction with children; didactic gaining knowledge on improving preschool education efficiency; psychological - conducting classes in psychology (general, developmental, pedagogical); physiological - conducting classes in physiology and hygiene; technical - the educator should be able to apply information and communication technologies in their work; selfeducational - reading special literature, attending seminars on relevant topics. Much attention is paid to such a pedagogical activity type consisting in development: preparation and implementation of training and education programs, modeling of situations and events developing the child's emotional and value sphere, creation of a comfortable educational environment.

Creation of effective conditions for the professional development of teachers of the preschool education and comprehensive continuous development of children, the quality of interaction with the family, determines the main tasks of methodological work: training and development of teaching staff; management of their qualification improvement; identification, studying, generalization and dissemination of advanced pedagogic experience of teachers; preparation of methodical support for the educational process; coordination of the activities of the preschool educational institution and the family in ensuring the comprehensive continuous development of pupils; coordination of activity of the 
preschool educational institution with other institutions for the realization of the tasks of development of children and the institution as a whole; analysis of the quality of work in order to create conditions for ensuring positive changes in the development of the personality of pupils through increased professional competence of teachers.

The objectives of methodological competence development in preschool teachers are achieved in the process of professional training and retraining, the improvement of methodological tools for methodological work, the development of learning and teaching materials where the environment and modern preschool children's development features are taken into account to the greatest extent.

\section{CONCLUSIONS}

Thus, the above-mentioned makes it possible to conclude that in the preschool teacher's professional and pedagogical competence structure a key role is played by methodological competence since its formation allows to solve professional problems in the process of realization of children's education, upbringing and development goals.

The main objectives of organizing methodological work in preschool institutions are the following: boosting teachers' professional and cultural level; improvement of the methods and styles of interaction with children based on the principles of humanization and democratization; upgrading educators' skills in organizing children's creative, research and independent activity; developing skills in the analysis of the educational process as a whole and self-reflection on one's own efficiency; involvement of educators in research activities based on innovative methods. The content of methodological work in preschool institutions is determined according to particular objectives. It also has to be taken into account educational process outcomes, teachers' qualification and staff morale.

Methodological competence is defined as the ability and willingness to plan and realize the educational process, as well as to self-reflect on one's own pedagogical activity formed at a basic level. The methodological competence essence is determined by the 
structure of the teacher's leading activity which allows considering it as a functional component.

Methodological competence is considered as a component of preschool teachers' professional and pedagogical competence. Thus, the concepts of "professional and pedagogical competence" and "methodological competence" correlate as general and singular respectively. It ensures the learning process effectiveness, because it enables to scientifically implement professional training principles, content, and forms involving the capacity for methodological selfanalysis, the ability to critically evaluate and review the quality of learning activities, to analyze used techniques and exercises in terms of their relevance and effectiveness.

\section{SUMMARY}

The following approaches to the definition of a professional competence phenomenon have been analyzed: function activity related, axiological, universal, personal activity related; the structure of key competences in education has been disclosed; the main components of professional competence of pedagogues and form of methodological work have been determined, aimed at development of competence of educators of pre-school educational institutions. In modern researches, terms "methodological competency" and "methodological competence" are often used as synonymous. The structure of the competence of the specialist involves experience (knowledge, skills), orientation (needs, values, motives, ideals), quality (ability to synergetic manifestations, adaptation, scaling and interpretation, self-development, integration, transfer of knowledge from one branch to another). Content of professional competence of a pedagogue of one or another major is determined by qualification characteristics. It constitutes a normative model of a pedagogue's competence, reflecting theoretically substantiated professional knowledge, abilities, skills. By conditional separation of professional competence from other personal transformations we mean that acquisition of knowledge is not a goal in itself but a very important condition for production of "knowledge in action", i.e. abilities and 
skills as a main criterion of a professional readiness. The structure of methodical competence as the result of the training of future educators of pre-school institutions is due to its components being the key, basic, special and partly professional competencies, each of which has a cognitive, activity and personal aspect. Organization of methodological activity is determined as an important factor of improvement the professional level of teachers of preschool educational institutions and one of the ways of reforming of education. It is noted that the main aim of methodological activity is scientific achievements and pedagogical experience as a complex system of interrelated measures, aimed at improving of qualification, professional skills and abilities of the teacher of the preschool educational institution and the entire pedagogical team.

\section{REFERENCES}

1. Adolf V. A. (2005) Obnovlenye protsessa podhotovky pedahohov na osnove modelyrovanyia professyonalnoi deiatelnosty [Updating of process of teachers training on the basis of modeling of professional activity]. Krasnoiarsk. (in Russian)

2. Alekseenko-Lemovska L. V. (2016) Scientific approaches to the problems of methodical competence of teachers in pre-school educational institutions. Nauka $i$ studia. Przemysl. Poland. Pedagogiczne nauki psichologia i socjologia, no. 24-4 (158), pp. 95-100.

3. Alekseenko-Lemovska L. V. (2015) Theoretical aspects of methodical competence of teachers of preschool educational institutions. Szkola - Zavod - Praca. Universytetu Kazemiera Wielkiego. Bydgoszcz, no. 10, pp. 11-19.

4. Belaia K. Iu. (2007) Metodycheskaia rabota $v$ DOU: Analyz, planyrovanye, formy y metody: metodycheskoe posobye [Methodical work in a preschool educational institution: Analysis, planning, forms and methods: a methodical manual]. Metodycheskoe posobye. M.: TTs Sfera. (in Russian)

5. Bibik N. M., Vashchenko L. S., Lokshyna O. I., Ovcharuk O. V. (red.) (2004) Kompetentnisnyi pidkhid u suchasnii osviti: svitovyi dosvid ta ukrainski perspektyvy : Biblioteka $z$ osvitnoi 
polityky [Competence approach in modern education: international experience and Ukrainian prospects: library of educational policy], K.: K.I.S. (in Ukrainian)

6. Edwards R., Nicoll K. (2006) Expertise, competence and reflection in the rhetoric of professional development. British Educational Research Journal, no. 32, pp. 115-131.

7. Hluzman O. V. (2009) Bazovi kompetentnosti: sutnist ta znachennia $\mathrm{v}$ zhyttievomu uspikhu osobystosti [Core competence: the nature and value of individual success in life]. Pedahohika $i$ psykholohiia, no. 2, pp. 51-60.

8. Hushchyna T. N. (2001) Formyrovanye metodycheskoi kompetentnosty pedahohycheskykh rabotnykov dopolnytelnoho obrazovanyia detei $v$ protsesse povyshenyia kvalyfykatsyy [Formation of methodical competence of teachers of the institute of additional education of children in the process of professional development]. Yaroslavl. (in Russian)

9. Khutorskoi A. V. (2003) Kliuchevye kompetentsyy kak komponent lychnostno-oryentyrovannoi paradyhmы obrazovanyia [Key competences as a component of personality-oriented educational paradigm]. Narodnoe obrazovanye, no. 2. pp. 58-64.

10. Kuzmyna N. V. (1990) Professyonalyzm lychnosty prepodavatelia y mastera proyzvodstvennoho obuchenyia [The professionalism of the teacher's personality and the master of industrial training]. M.: Vysshaia shkola. (in Russian)

11. Krutii K. L. (2003) Innovatsiina diialnist v suchasnomu doshkilnomu navchalnomu zakladi: metodychnyi aspekt [Innovative activity in a modern preschool educational institution: methodical aspect]. Zaporizhzhia: LIPS LTD. (in Ukrainian)

12. Savchenko O. P. (2010) Kompetentnisnyi pidkhid u suchasnii vyshchii shkoli [Competency approach in modern universities]. Pedahohika i nauka: istoriia, teoriia, praktyka, tendentsii rozvytku, no. 3, pp. 16-23.

13. Sharmahd N., Peeters J., Bushati M. (2018) Towards continuous professional development: Experiencing group reflection 
to analyse practice. European Journal of Education, no. 53 (1). pp. 58-65.

14. Slastenyn V. A., Ysaev Y. F., Shyianov E. N. (2002) Pedahohyka [Pedagogy]. Ucheb. posobye dlia stud. vyssh. ped. ucheb. zavedenyi. M.: Akademyia. (in Russian)

15. Ylenko L. Y. (2003) Teoryia y praktyka upravlenyia metodycheskoi rabotoi $v$ obrazovatelnykh uchrezhdenyiakh [Theory and practice of methodological work management in educational institutions]. M.: ARKTY. (in Russian)

\section{Information about the author:}

\section{Liudmyla Aleksieienko-Lemovska,}

Candidate of Pedagogic Sciences, Associate Professor, Professor at the Department of Pedagogy and Psychology, Early Childhood Education and Children's Art, National Pedagogical Dragomanov University 8/14, Turgenev str., Kyiv, 02000, Ukraine ORCID ID: orcid.org/0000-0001-5391-0719 
DOI https://doi.org/10.36059/978-966-397-161-2/49-69

\section{MOBBING IN ORGANIZATIONS: THE TYPOLOGICAL- STRATEGIC APPROACH}

\section{Zinoviia Karpenko}

\section{INTRODUCTION}

The dynamics of changes in social relations in Ukraine, despite complaints about their morbidity, inconsistency, slowness, is still accelerating. This leads, among other things, to intensification of competitiveness in the labour market. On the one hand, the objective need for competent specialists able to work in accordance with modern professional requirements grows, and on the other hand, it triggers personal motivation to preserve and enhance own status, prestige, influence on other people, control over own life, etc. Contradictions exists between the interest of society in maximal progressive transformations and enhanced production productivity, as well as in improved state and corporate governance, better education, science, culture, medicine, stronger defence and law enforcement agencies, etc., from one side, and an ordinary citizen's personal, often subconscious, resistance to "start a causal series form him/herself", his/her naturally predisposed tendency to minimize efforts, from the other side; these contradictions generate tension in the professional environment, leads to conflicts and their non-constructive devolution, such as mobbing ${ }^{1}$.

Paradoxically, people encounter mobbing during the most productive period of their lives, when they acquire a profession, gain professional experience and reach the tops of their professional skills, the so-called, acme-period. It is assumed that professional development, as a rule, is synchronized with personal maturity that is characterized by a developed axiological sphere, prosocial behaviour,

${ }^{1}$ Karpenko Z. S. (2012) Prykladna konfliktolohiia [Applied Conflictology]: navch.-metod.posib. Ivano-Frankivsk: IFOTsPPK. (in Ukrainian). 
ability for civic solidarity and adherence to ethical standards. However, in reality, we can see often de-synchronization of subjectactivity (professional) and motivational-value (personal) lines of acme-genesis, which is the significant socio-economic, organizationalindustrial and personal problem ${ }^{2}$.

The purpose of this theoretical exploration is to model conceptually the causes of mobbing at labour collectives, to build the typology of mobbing and mobbers, and to classify strategies preventing and counteracting mobbing, inter alia, through the correction of a personal life scenario.

\section{Mobbing as a subject of psychological research}

Mobbing, which means oppressing, harassment, attacking, is a kind of psychological pressure, during which an employee feels unbearable atmosphere in his/her organization because of claims to his/her work quality or found personal faults. The mobbing ultimate goal is to make the employee leave his/her workplace or, at least, reduce his/her social or professional influence at the organization ${ }^{3}$. In other words, mobbing is a psychological terror for an employee that

${ }^{2}$ Varfolomeieva O. (2007) Akmeolohiia yak nauka v interpretatsii rosiiskykh doslidnykiv [Acmeology as a science in the interpretation of Russian researchers]. Sotsialna psykholohiia [Social Psychology], no. 4, pp. 27-36. (in Ukrainian) ; Humeniuk U. I. (2011) Kontseptualni osnovy vyvchennia akmeperiodu liudyny [Conceptual bases of study of human acmeperiod]. Naukovi zapysky. Seriia «Psykholohiia i pedahohika» [Proceedings. Psychology and Pedagogy Series]. Ostroh: Vydavnytstvo Natsionalnoho universytetu «Ostrozka akademiia», no. 17, pp. 72-82. (in Ukrainian) ; Larchenko N. A. (2015) Mobbing, ili psikhologicheskoye nasiliye $v$ trudovom kollektive : metodicheskiy material (dlya administratsii, rabotnikov trudovykh kollektivov) [Mobbing, or psychological violence in the workforce: methodological material (for the administration, employees of work collectives)]. Volgograd. (in Russian) ; Nevskaya D. R. Esli vuzovskiy mobbing sushchestvuyet, znachit, eto komu-to nuzhno [If university mobbing exists, then someone needs it]. Retrieved from: http://mobbingu.net/articles/detail/18 (accessed 25 May 2018) (accessed 5 November 2019).

${ }^{3}$ Babanov S. A. Psikhologiya truda. Mobbing kak patologicheskaya forma professional'nogo destruktivnogo povedeniya [The psychology of labor. Mobbing as a pathological form of professional destructive behavior]. Retrieved from: http://www.kiout.ru/info/publish/24214 (accessed 25 May 2018). 
appears both in the rude, outspoken form (such as constant scoffing, reprimands for slightest missteps and neglect of well-done cases), and in the veiled form, for example, a crooked smile accompanied by a mocking look directed at a colleague, making fun of his/her dressing patterns, used dialect words, physical disabilities or low social background. It is especially grievous when a coalition is created against an undesirable person. The active participants of mobbing, socalled mobbers (it is sometimes some individuals, but, more often, a chasing group) want to disorient their victim, impair his/her mental equilibrium, push to wrong decisions because of prolonged stress; such an aim is achieved by distorted ambiguous messages addressed to the victim, dirty rumours about the employee's personal life that also covers his/her business reputation, etc.

In the review made by S.A. Babanov, he states that the concept of "mobbing" was introduced by K. Lorenz to describe behaviour of several smaller (weaker) animals united against a larger (stronger) enemy. For the first time, the term was used by Swedish physician P.-P. Heinemann in 1972, who noted the meaningful similarity between the behaviour of animals and children abusing their peers. Subsequently, his compatriot H. Leymann extended this concept understanding onto description of destructive relationships at a workplace. The first well-argued psychological study of mobbing was the book of the author team (N. Davenport, R. Schwartz, G. Elliott) published in 1999 in the USA: "Mobbing, Emotional Abuse in the American Workplace", which examined this phenomenon emergence and dynamics, its consequences and harm to a company, as well as possible ways to prevent $\mathrm{it}^{4}$. In particular, three levels of mobbing and their consequences for its victim's physical or mental state are distinguished: at the first level, a victim is able to resist, get through bullying at an early stage, or recover fully at a new workplace; at the

\footnotetext{
${ }^{4}$ Babanov S. A. Psikhologiya truda. Mobbing kak patologicheskaya forma professional'nogo destruktivnogo povedeniya [The psychology of labor. Mobbing as a pathological form of professional destructive behavior]. Retrieved from: http://www.kiout.ru/info/publish/24214 (accessed 25 May 2018).
} 
second level, the victim cannot withstand the pressure or flee immediately, suffers mental and / or physical trauma for some time and has difficulties in returning to work; at the third level, the victim is unable to recover his/her ability to work and suffers severe, prolonged mental disorder or physical disability.

The well-argued study of mobbing in Germany was carried out at the same time by D. Zapf ${ }^{5}$. The scientist compared the mobbing qualitative and quantitative characteristics in different European countries and in different industries and justified the economic losses of organizations because of mobbing at workplaces as well as destructive impacts of mobbing on its victims. Later P. Stadler, a fellow countryman of D. Zapf, systematized the causes, consequences, and strategies for mobbing prevention or its stopping in organizations ${ }^{6}$.

In the latest study of mobbing - the monograph presented by the author group and edited by M. Duffy and L. Sperry, mobbing is seen as a form of interpersonal abuse occurring in all main human institutions and organizations such as schools, workplaces, religious organizations, the legal system and the communities where people live, for example, condominiums and homeowners associations. The mobbing victims are portrayed in a negative light to get them out of their organization or to suspect them in something inappropriate if they remain at the organization. The book provides a thorough analysis, which relies on research started in the 1970s, on what is mobbing, on its devastating effects and strategies for individual and organizational recovery and mobbing prevention ${ }^{7}$.

${ }^{5}$ Zapf D. (1999). Mobbing in Organisationen - "Uberblick zum Stand der Forschung. Zeitschrift fur Arbeits- und Organisationspsychologie, 43, 1-25.

${ }^{6}$ Stadler P. Mobbing am Arbeitsplatz - Ursachen, Folgen sowie Interventionsund Präventionsstrategien. Retrieved from: Retrieved from: http:// www.forschungsnetzwerk.at/downloadpub/Mobbing_am_Arbeitsplatz_stadler.pdf (accessed 3 November 2019).

${ }^{7}$ Duffy M., Sperry L. (2012). Mobbing: Causes, Consequences and Solutions. Retrieved from: https://www.oxfordscholarship.com/view/10.1093/acprof:oso/ 9780195380019.001.0001/acprof-9780195380019 (accessed 3 November 2019). 
Recently, E.H. Toytok, a Turkish researcher, introduced to the scientific community the results of his large-scale correlation study of educational workers that proved links between mobbing and so-called organizational depression, which is manifested in the depressing mood because of lost career prospects and refusal to fight for the rights and human dignity ${ }^{8}$.

After these discoveries, purely scientific and psychological interest on mobbing moved into the field of labour law amending at many Western countries, and research results influenced humanresource policies and organizational management of private firms, corporations, and public institutions ${ }^{9}$.

As for the post-Soviet countries, the special studies on mobbing began only two decades later and became the subject of interdisciplinary studies in the fields of jurisprudence, conflict management, economic and organizational psychology, etc. For example, J. Weinhardt, a Lithuanian researcher, describes mobbing as discrimination in employees' relations, as a constant terror that manifests itself in attack frequency and duration. She notes that mobbing victims experience psychological discomfort, mental suffering, and this has a negative impact on the victims' social, professional behaviour. She considers also consequences of this phenomenon for moral and psychological climate at organizations, and for the mobbing victims ${ }^{10}$.

But despite certain shifts and gains, a synthetic methodological platform is absent that would allow us to apply the typological-

${ }^{8}$ Toytok E. H. (2017) Perception of Mobbing by Teachers and Organizational Depression: A Correlational Model Study Universal Journal of Educational Research, 5(12A): 168-175.

${ }^{9}$ Patlasov O. YU., Kalmykov I. S. (2016) Tekhnologii protivodeystviya mobbingu personala na rabochem meste [Counter-mobilization technologies for personnel at the workplace]. Nauka o cheloveke : gumanitarnyye issledovaniya [Human Science: Humanitarian Studies], no. 1, pp. 234-242.

${ }^{10}$ Vveinhardt J. (2010) The diagnostics of mobbing as discrimination in employee relations aiming to improve the organizational climate in Lithuanian organizations. Management theory and studies for rural business and infrastructure development. 21 (2), 173-184. 
strategic approach to the interpretation of the studies phenomenon, not only to see in it a destructive threat for employees' self-esteem and a violation of their ego-identity, but also to note in the mobbing situation possible changes, latent opportunities that need to be used as corrections to a person's life scenario. Therefore, mobbing should also be considered as a chance to adjust a person's life path, to re-plan his/her career, including its radical options - professional retraining, participation in psychotherapy groups, emigration, etc.

This study presents the results of the research used qualitative (hermeneutic) methods: phenomenological, discursive, narrative and conversion analysis; the method of long-term included observations, conversations, and discussions in focus groups.

We should note that so-called university mobbing rarely becomes the subject of special studies. D.R. Nevska in her well-known study names the distinctive marks of such mobbing in Russia. Given the common post-Soviet heritage, her conclusions can be applied to the Ukrainian academic sphere. These features are:

1) a highly qualified lecturer/researcher, who demonstrates his/her independence, professionalism and passion for work, can cause irritation of his/her managers or less professional colleagues; and this induce mobbing;

2) "ballast" - "odd" employees (inexperienced young lecturers or older lecturers on the retirement age) can become victims of mobbing;

3) mobbing can be initiated by a department head, who encourages confrontation between employees in order to create an impression that he/she is above the quarrels and obtain the right to manipulate his/her subordinates;

4) a leader who is not enough self-confident and hold his position for a long time is inclined to press "free-thinking" to get rid of potential competitors - highly qualified or "non-loyal" employees;

5) a leader suffering professional deformation can abuse his/her power by violations of professional ethics as for his/her colleagues;

6) a quite common cause for university mobbing is banal envy of more successful, talented colleagues, when own achievements 
against the background of virtues of such employees are seen meagre; such an unhealthy and aggressive reaction as mobbing can appear as a result such comparison of professional competencies and achievements $^{11}$.

\section{The typology of mobbing and mobbers}

The empirical typology of mobbing, proposed by Leymann in 1993, is still very popular. This pioneer in mobbing studies identified 5 varieties of mobbing at different organizations, which together cover 45 actions. Such actions are: limitations of an employee's ability to express him/herself (for example, with constant interruptions, threats, critics, interference into his/her private life, etc.); oppression of an employee in his/her professional environment (mobbers do not talk to the employee, get away from he/her, transfer him/her to work into an isolated room, etc.); undermining of an employee's authority and social status (dissemination of gossips, blames, false information about his/her physical or mental disabilities, ridiculing of his/her manner of speaking or dressing, poking at his/her religious believes or ethnicity, indecent suggestions, etc.); creation of conditions that reduce quality of his/her work and life in general (the employee does not obtain any task or is given too complex or meaningless tasks to discredit him/her as a specialist); coercion to harmful work (threat of physical violence of real physical violence, damage of the employee property, sexual harassment, etc. $)^{12}$.

The typology proposed by me is based on the idea of the evolutionary advantage of altruistic motivation of personal behaviour, self-actualizing in deeds good for all community in comparison with selfish motivation of a person opposing him/herself to society. Such selfish motivation means a person's desire and ability to impose

${ }^{11}$ Nevskaya D. R. Esli vuzovskiy mobbing sushchestvuyet, znachit, eto komuto nuzhno [If university mobbing exists, then someone needs it]. Retrieved from: http://mobbingu.net/ articles/detail/18 (accessed 25 May 2018) (accessed 5 November 2019).

${ }^{12}$ Leymann H. (1993) Mobbing, Psychoterror am Arbeitplatz und wie man sich dagegen wehren kann. Reinbek bei Hamburg Rowohlt-Taschenbuch-Verl. 
his/her will by force or mental means on other people in order to satisfy his/her selfish interests. Therefore, mobbers are characterized by insensitivity (or low sensitivity) to moral laws, parasitism, the desire for unlimited power and material goods, intrigue, malice, etc.

A mobber, often motivated by purely private goals, uses a variety of manipulative strategies to achieve the mobbing goal - to bring a victim to despair that cuts paths to understanding and status quo restoring. In fact, mobbing is not motivated by the idea to find a true price for everyone (rather, it is revealed over time), but solely to win the right of the strong; this is a narrow selfish interest, determined by the inherent human motivation to survive in any circumstances (as a minimum), to win the competition for resources and, even better, to live with a guarantee (maximum). Namely, this "selfish gene" backs human striving for achievements, career development, budget planning and caring for wealth ${ }^{13}$.

However, another, equally natural, motivation exists to get along well with people in a group, to share its values and to be involved in solving of its problems and tasks; this motivation includes strive for selflessness and selfless service just as the desire to receive benefits. Moreover, altruism is not a metaphysical, "spiritual" alternative to "animal" selfishness, but is a reasonable, evolutionarily justified counterbalance to selfishness that limits perspectives of human development ${ }^{14}$. Mobbing actors do not generally take into account altruistic impulses; they live in a world of exploitation, selfinterest, and personal gains. The motivation characteristic for people who are sincere in their service for social good irritates mobbers, because it is something that they forced out and neglected in their inner worlds. Therefore, they direct their aggression of survival and subjugation to those "weaklings" who live in another value system. Russian).

${ }^{13}$ Dokinz R. (2013). Egoistichnyy gen [Selfish gene]. Moscow: ACT. (in

${ }^{14}$ Levit L. (2016) Evdemonizm protiv ekzistentsializma: eshche raz o tsennostyakh i smysle zhizni [Eudaimonism versus existentialism: once again about the values and meaning of life.]. Psykholohiia osobystosti [Psychology of personality], vol. 1, no. 7, pp. 33-48. (in Russian). 
Who uses mobbing most often?

Thus, there are a totally egoistic, grabbing motivational platform common for all mobbing agents, in general, and a number of characters practicing certain mobbing types in accordance with the causes preconditioning this phenomenon, in particular:

1) a witling and narrow-minded individual, without clear professional interests and low moral standards, as well as envy for those "who need more than others"; the primitive mobbing type;

2) people whose life credo is avoiding and to go with flow; the philistine mobbing type;

3) incompetent employees who have taken their office positions due to corrupt employment schemes; corrupt mobbing type;

4) employees with ambitions and self-esteem exceeding their real capabilities and achievements; the narcissistic mobbing type;

5) power-seeking "award collectors", swollen-headed and walking all over because of their "blue blood" (most often, belonging to the nomenclature or the so-called "new Ukrainians") who received specific education; the totalitarian mobbing type.

The given typology specifies the author's principle of integral subjectivity, according to which personal formation and development takes place in an ascending teleological perspective: the sub-subjective or relatively subjective (lowest) level of realization (here - destructive fixation) of an employee's subject-value potential, expressed by the primitive type of a mobber; fixation on narrowly selfish interests and needs - the mono-subjective (here - philistine) type of a mobber; at the poly-subjective level - the levels of internationalized anti-social morality - the corrupt mobbing type and the corresponding mobber appears; at the meta-subjective level of human potential realization, the narcissistic type of mobbing is formed, a mobber seeks for uncritical approval and unrestricted satisfaction of own ambitions by as wide a circle of people as possible, the most influential ones; and the totalitarian mobbing type and a totalitarian mobber correspond to the totally subjective, universal level. Let us note that with the transition to a new, higher mobbing level, mobbers obtain wider opportunities and the harm from their psychological terror toward 
colleagues grows. That is why organizations must counterwork against mobbing.

\section{Strategies for counterwork against mobbing}

Depending on the mobbing (mobber) type, we differentiate strategies to counteract this phenomenon.

1. Normative-regulatory strategy. Mobbers belonging to the primitive category detest people who "need more than others" and are unpretentious in their means. They often use coarse swearing, abusive nicknames, mockery, bullying, malicious actions that dishonour an employee in his/her manager's eyes or worsen his/her business image. In addition to general intolerance to people who are inclined to work with pleasure, strive for better results, exhibit the so-called extranormative or altruistic actions, primitive mobbers are intolerant to manifestations of individual differences, tastes, preferences, personal autonomy if such manifestations do not correspond their limited (backward-provincial, narrow-traditionalist, etc.) understanding of means for self-expression, self-presentation and self-determination. It is not surprising that fierce ethno- and homophobes, supporters of racist and religious-fundamentalist ideologies appear in such environment. In the latter case, such mobber go out of the narrow frames of primitive mobbing and use other varieties of violent, hostile behaviour, such as totalitarian-dominating mobbing, fuelled by the collective narcissism of groups that believe they are not worthless at the arena of important geopolitical events despite the fact that other people do not share this point of view.

As for counteracting against primitive mobbing, we believe that "the might makes right" approach is pessimistic and provokes a force repulse. It is known from experience that the professional environment must not tolerate aggressive ignorance and moral inferiority. Well regulated scale of rewards and punishments, fairness in assessments of each employee's individual contribution to the organizational efficiency, valid punitive sanctions concentrate employees' attention on objective work indicators and encourage labour enthusiasm, initiatives and cooperative work. In fact, the indifference to primitive 
mobbing manifestations make non-motivated workers feel unpunished and allows them to go off the reservations against people seeking fulfilment their talents and increasing of own competencies.

2) Differentiating-analytical strategy. Mobbing of professionally mediocre people, who consider work solely as a means of life support for their families, is brutal and arrogant but disguised by their position of a victim. Their intention of "do not touch me and I will not engage you!" means their constant willingness to avoid risks, responsibilities, acquisition of new competencies; in the case when their "professional growth" is threatened because a fair competition for a particular work position they show unexpectedly high activities to find influential supporters, powerful patrons who put into the place all imaginary offenders of this "nice in every sense" person.

The only way to counter mobbing from a victim's position is to differentiate between personal and professional histories, to reject extra-professional arguments and sentiments when the question is on the viability of an organization as a healthy whole organism, consolidated by shared goals and values.

3) Demonstrative-reflexive strategy. The incompetent people should be extracted from the web of gossip by the reflecting rays of publicity, where their professional inability become apparent. In this case, a mobbing actor is deprived of doubtful authority as an expert in human qualities, and his/her influence on opinions of the professional group drops to zero. The situation is worse, when incompetent mobbers are backed by their patrons from higher levels of the organizational hierarchy, who remove them every time out of criticism, preventing them from "shining" in a role disadvantageous for their false authority.

4) Creative-variative, anti-crisis strategy. Often enough professionally competent workers fall into this category of mobbers. For such mobbers, simple discredit of employees is too small goal (they simply "flex muscles"). Their main purpose is to find a right moment to catch a "bigger fish", for example, to undermine their leader's authority and dishonour him/her. Such workers create small coalitions of the "elected people" and attract attention of higher 
management in order to convince them in their professional "superiority" (compared to capabilities of their "stagnant" environment) and to achieve a privileged position, for example, as leaders.

This kind of mobbing can have not only negative consequences for the organization and its leaders. Firstly, it can lead to the reorganization of an organizational department or even its liquidation, merger with others sub-divisions, as well as to establishment of new departments, centres, etc. Secondly, a leader, if he/she can withstand emotional burnout and professional distortion, is able not only to restore but also to strengthen his/her own authority in his/her organization or at other institutions. Thirdly, the mobbers receive an opportunity to adjust their self-esteem, to defend and confirm the validity of advances and privileges from senior management, which they received as a reward for combating a former leader as "the evil and the brakes of progress".

The victim's strategy in this difficult situation is not to be trolled, to maintain courage in conditions when his/her team is staggered because it doubts in his/her leadership abilities. The mocked leader has several options: to unite the rest of his/her team on the basis of common values, goals and deeds; to demonstrate to the top management that his/her team is an able functional units under his/her leadership; to be fired in the case of insufficient support from top and bottom for other career prospects.

5) Systemic-corrective strategy. As for pathological powerseekers, their tyranny can be stopped only by the organized resistance of all employees as a united group, who do not want to submit to his/her high-handedness or even arrogance, absence of democratic principles in their organization, to recognize the under-the-carpet agreements aimed at strengthening of power monopoly and the related advantages of such an official ${ }^{15}$. The tacit consent of subordinates and colleagues legitimizes really the self-serving short-legged motive of a

${ }^{15}$ Bondarchuk M. (2007) Nachyzm. Ternopil: Pidruchnyky i posibnyky. (in Ukrainian). 
person who abuses his/her powers. As a matter of fact, a careeristpower seeker is a universal mobber, so combating his/her manipulative methods requires civil dignity and professional honour, a willingness to face unforeseen difficulties and to take responsibility for own solutions; this struggle must be systematic and fought at different levels of the organizational hierarchy.

The presented conceptual modelling is not the result of an arbitrary imagination, since it is based on the solid factual base and the recognizable psychological phenomenology. It follows from this fact that mobbing prevention and counteraction requires different measures: the legislative regulation of labour relations, work with the organizational staff, as well as individual reflexive, volitional efforts and creative decisions made by every employs. We talk on the transactional analysis of habitual patterns of an individual's behaviour that shape his/her life strategy on the path of a Winner, a Defeated person or some intermediate variant ${ }^{16}$. Mobbers, as a rule, tend to elevate above their victim with aggressively manipulative means; in turn, the victim is victimized if he/she uses unproductive forms of psychological protection. In both cases, a negative life experience should be re-constructed, its components should be externalized and a viable and competitive narrative personal identity should be built ${ }^{17}$. So, renovated personality will practice kindness instead of hostility, affection instead of suspicion, friendly sympathy instead of envy, work on him/herself instead of hindering their colleague's success. In general, we can say that practically every psychotherapeutic approach has psychological techniques adequate for different situations (and types) of mobbing and capable to assist its potential or real victim.

${ }^{16}$ Mizinova I. A. (2013) ZHiznennyy stsenariy lichnosti: osnovne podkhody k rassmotreniyu [Life scenario of an individual: basic approaches to consideration]. Izvestiya Saratovskogo universiteta. Novaya seriya. Seriya Filosofiya. Psikhologiya. Pedagogika [News of the Saratov University. New episode. Philosophy Series. Psychology. Pedagogy], vol. 13, no. 4, pp. 59-64. (in Russian).

${ }^{17}$ Berezko I. V. (2014) Kryzova sytuatsiia: bifurkatsiia u zhyttievomu stsenarii [Crisis situation: bifurcation in life scenario]. Aktualni problemy psykholohii [Actual problems of psychology], vol. 2, no. 8, pp. 109-122. (in Ukrainian). 
M. Bondarchuk provides useful recommendations on counteraction to bossing (a type of vertical mobbing initiated and supported by a boss against his/her subordinates $)^{18}$ :

- it is important for bossing victims not to retire into themselves or accumulate anger and irritation for the joy of the boss-manipulator, but to resist with all available means, uniting with others in the fight for the fair order;

- dissemination of credible information about intrigues, arbitrariness or frauds of a particular boss narrows the field of his/her activity, warns and equips his/her potential victims;

- actions of state authorities and local self-government bodies should be under the watchful eye of the opposition parties and movements; officials should be under constant control of the public;

- in a broad sense, a clear and strong system of state power together with strong and developed civil society and a legal system fighting power abuse are needed.

On the basis of the analysed current situation with mobbing at workplaces and the analysed foreign legislation protecting employees against mobbing, O.Yu. Patlasov and I.S. Kalmykov propose to implement the following initiatives at organisations:

1) to introduce in organizations of a code of conduct containing the concept of "mobbing", descriptions of behaviour and actions falling under this definition, as well as the sequence of actions that can be used by an employee suffering or witnessed mobbing, and sanctions that can be applied to mobbers;

2) to monitor the psychological climate in an organization with such means as seminars and webinars aimed at formation of a corporate spirit and explanation of the negative effects of mobbing; to introduce into the practice a "farewell interview" finding reasons for an employee's dismissal;

${ }^{18}$ Bondarchuk M. (2007) Nachyzm. Ternopil: Pidruchnyky i posibnyky. (in Ukrainian). 
3) to form such internal environment in an organization that would facilitate the quick and painless entry of a new employee into the labour collective;

4) to make amendments to the labour legislation concerning the protection of both employees' physical and mental health, as well as the liability of those who violate employees' rights and legitimate interests;

5) the liability for damages caused to a employee must be laid upon his/her employer;

6) to protect legally an employee's right at court examinations concerning his/her dismissal or disciplinary actions, and to provide sanctions against employees giving false information about mobbing for their personal gains ${ }^{19}$.

\section{CONCLUSIONS}

The mobbing motives, mobber's psychological types, and strategies of counteraction, described in this article, are not defined absolutely clearly, because they are rarely seen in real life in their pure forms. The described types do not create a comprehensive classification of mobbing and its actors; in additions, they are, undoubtedly, culturally determined. There are reasons to expect that mobbing manifestations and its main forms are influenced by peculiarities of national character, dominant social attitudes and stereotypes, moral and psychological state of society, its justice, elaboration and application of the legislative rules as for labour relations in a particular country. On the other hand, there are doubts about possibility to develop strict valid protocols how to eliminate the behavioural violations if such task is applied to mobbers themselves.

Qualified organizational psychologists, trained HR-managers could help in this case, however, despite urgent demand for their work,

${ }^{19}$ Patlasov O. YU., Kalmykov I. S. (2016) Tekhnologii protivodeystviya mobbingu personala na rabochem meste [Counter-mobilization technologies for personnel at the workplace]. Nauka o cheloveke : gumanitarnyye issledovaniya [Human Science: Humanitarian Studies], no. 1, pp. 234-242. 
they rarely appears in the staff list of organizations ${ }^{20}$. Another institution, the trade union, as a body protecting the working people rights, is very rarely interested in psychological motives of mobbing and deals mainly with consequences of particularly malignant forms of this phenomenon. Various temporary commissions considering complaints and labour disputes have a palliative effect and influence very little on the formation of a favourable moral and psychological organizational climate. There is a need for special training for organizational administrative staff and heads of structural units as for mobbing prevention and productive conflict resolution. For this purpose, rich international experience can be used ${ }^{21}$.

In general, we talk on the axiopsychological culture based on the humanistic principles of the professional environment (an organization), which can minimize the manifestations of individualistic short-sightedness, defensive suspicion, aggressive defence of "own territory", attempts to eliminate rivals in their claims for influence and power ${ }^{22}$.

Respect for people, their differences, experience; focus on fairness, objective assessments of situations and people's needs, friendly attitude to colleagues; flexible responds to misunderstandings, attempts to reveal causes of meaningful barriers; an integral problem vision with predicted consequences of problem possible solutions; a communication initiative combined with personal responsibility are the basic principles of counteraction against mobbing in the

${ }^{20}$ Hrabovska S. A. (2014) Psykholohichni aspekty komunikatsiinoho menedzhmentu orhanizatsii [Psychological aspects of communication management of the organization] : navch. posibnyk. Lviv: LNU imeni Ivana Franka. (in Ukrainian).

${ }^{21}$ People to People Communication - Preventing and Resolving Harassment for a Healthy Work Environment. Retrieved from: https:/www.canada.ca/en/treasuryboard-secretariat/services/healthy-workplace/prevention-resolution-harassment/peopl e-to-people-communication-preventing-resolving-harassment-healthy-work-environm ent.html (accessed 4 November 2019).

${ }^{22}$ Karpenko Z. S. (2009) Biolohichne sprychynennia v konteksti psykholohichnoi bezpeky osobystosti [Biological reasoning in the context of the psychological security of the individual]. Proceedings of the Psykholohichna bezpeka osobovoho skladu sylovykh struktur ta personalu ekstremalnykh profesii (Ukraine, Kharkiv, November 18, 2009). Kharkiv, pp. 69-72. (in Ukrainian). 
professional environment. Only socially optimistic thinking and activities aimed at a common good, empathy with people around, teamwork facilitation and constructive conflict resolutions ${ }^{23}$ can be positive means preventing such an abdominal (in the moral-aesthetic sense), deviant (in the socio-psychological sense) and harmful (in medico-psychological sense) phenomenon as mobbing.

\section{SUMMARY}

The article substantiates the socio-economic, political, legal, moral and psychological importance of the study on mobbing in professional interactions of employees within their organization. Despite the fact that a person's professional achievements appears at the acme-period, personal maturity does not always appears during this period. The need to compete for a job in the labour market, a weak organizational culture, and employees' individual characteristics supporting unproductive life scenarios lead to appearance of mobbing as harassment and tormenting of a colleague in order to discredit him/her, exclude him/her from society, and forcibly induce him/her to quit the job.

Basing the principle of integral subjectivity, we performed the conceptual modelling of subjective-value behavioural preferences of different mobbing types and mobbers as its actors - primitive, philistine, corrupt, narcissistic, totalitarian - used in an employee's acme-period.

The strategies for mobbing prevention and counteraction are distinguished and characterized, taking into account the psychological profile of the mobbing actors: normative-regulatory, differentialanalytical, demonstrative-reflexive, creative-variative, systemiccorrective.

We assume that psychological techniques from the transactional analysis and narrative psychotherapy can help to correct the life scenario of employees involved in mobbing, by building of a resilient

${ }^{23}$ Seligman M. (2006) Novaya pozitivnaya psikhologiya [New positive psychology]. Moscow: Sofiya. (in Russian). 
and competitive narrative identity, adequate to the changed conditions of professional environment.

In general, social optimism, focus on the common good, empathy with people around, teamwork as cooperation, constructive resolutions of business conflicts are positive means preventing and countering mobbing in the professional environment.

The prospects for the future study are related to experimental confirmation of the developed mobbing (mobbers) typology and strategies for its prevention and elimination, the development of psychological and legal recommendations for professional conflict resolutions in the professional environment and for protection of employees' rights, especially those who are prone to victimization.

\section{REFERENCES}

1. Babanov S. A. Psikhologiya truda. Mobbing kak patologicheskaya forma professional'nogo destruktivnogo povedeniya [The psychology of labor. Mobbing as a pathological form of professional destructive behavior]. Retrieved from: http://www.kiout.ru/ info/publish/24214 (accessed 25 May 2018).

2. Berezko I. V. (2014) Kryzova sytuatsiia: bifurkatsiia u zhyttievomu stsenarii [Crisis situation: bifurcation in life scenario]. Aktualni problemy psykholohii [Actual problems of psychology], vol. 2, no. 8, pp. 109-122. (in Ukrainian)

3. Bondarchuk M. (2007) Nachyzm. Ternopil: Pidruchnyky i posibnyky. (in Ukrainian).

4. Varfolomeieva O. (2007) Akmeolohiia yak nauka v interpretatsii rosiiskykh doslidnykiv [Acmeology as a science in the interpretation of Russian researchers]. Sotsialna psykholohiia [Social Psychology], no. 4, pp. 27-36. (in Ukrainian).

5. Hrabovska S. A. (2014) Psykholohichni aspekty komunikatsiinoho menedzhmentu orhanizatsii [Psychological aspects of communication management of the organization] : navch. posibnyk. Lviv: LNU imeni Ivana Franka. (in Ukrainian).

6. Humeniuk U. I. (2011) Kontseptualni osnovy vyvchennia akmeperiodu liudyny [Conceptual bases of study of human 
acmeperiod]. Naukovi zapysky. Seriia "Psykholohiia i pedahohika" [Proceedings. Psychology and Pedagogy Series]. Ostroh: Vydavnytstvo Natsionalnoho universytetu "Ostrozka akademiia", no. 17, pp. 72-82. (in Ukrainian).

7. Dokinz R. (2013). Egoistichnyy gen [Selfish gene]. Moscow: ACT. (in Russian).

8. Karpenko Z. S. (2009) Biolohichne sprychynennia v konteksti psykholohichnoi bezpeky osobystosti [Biological reasoning in the context of the psychological security of the individual]. Proceedings of the Psykholohichna bezpeka osobovoho skladu sylovykh struktur ta personalu ekstremalnykh profesii (Ukraine, Kharkiv, November 18, 2009). Kharkiv, pp. 69-72. (in Ukrainian).

9. Karpenko Z. S. (2012) Prykladna konfliktolohiia [Applied Conflictology]: navch.-metod.posib. Ivano-Frankivsk: IFOTsPPK. (in Ukrainian).

10. Larchenko N. A. (2015) Mobbing, ili psikhologicheskoye nasiliye $v$ trudovom kollektive : metodicheskiy material (dlya administratsii, rabotnikov trudovykh kollektivov) [Mobbing, or psychological violence in the workforce: methodological material (for the administration, employees of work collectives)]. Volgograd. (in Russian).

11. Levit L. (2016) Evdemonizm protiv ekzistentsializma: eshche raz o tsennostyakh i smysle zhizni [Eudaimonism versus existentialism: once again about the values and meaning of life.]. Psykholohiia osobystosti [Psychology of personality],. vol. 1, no. 7, pp. 33-48 (in Russian).

12. Mizinova I. A. (2013) ZHiznennyy stsenariy lichnosti: osnovne podkhody $\mathrm{k}$ rassmotreniyu [Life scenario of an individual: basic approaches to consideration]. Izvestiya Saratovskogo universiteta. Novaya seriya. Seriya Filosofiya. Psikhologiya. Pedagogika [News of the Saratov University. New episode. Philosophy Series. Psychology. Pedagogy], vol. 13, no. 4, pp. 59-64. (in Russian).

13. Nevskaya D. R. Esli vuzovskiy mobbing sushchestvuyet, znachit, eto komu-to nuzhno [If university mobbing exists, then 
someone needs it]. Retrieved from: http://mobbingu.net/articles/ detail/18 (accessed 25 May 2018) (accessed 5 November 2019).

14. Patlasov O. YU., Kalmykov I. S. (2016) Tekhnologii protivodeystviya mobbingu personala na rabochem meste [Countermobilization technologies for personnel at the workplace]. Nauka o cheloveke : gumanitarnyye issledovaniya [Human Science: Humanitarian Studies], no. 1, pp. 234-242.

15. Seligman M. (2006) Novaya pozitivnaya psikhologiya [New positive psychology]. Moscow: Sofiya. (in Russian).

16. Duffy M., Sperry L. (2012). Mobbing: Causes, Consequences and Solutions. Retrieved from: https:// www.oxfordscholarship.com/view/10.1093/acprof:oso/978019538001 9.001.0001/acprof-9780195380019 (accessed 3 November 2019).

17. Leymann H. (1993) Mobbing, Psychoterror am Arbeitplatz und wie man sich dagegen wehren kann. Reinbek bei Hamburg Rowohlt-Taschenbuch-Verl.

18. People to People Communication - Preventing and Resolving Harassment for a Healthy Work Environment. Retrieved from: https://www.canada.ca/en/treasury-board-secretariat/services/ healthy-workplace/prevention-resolution-harassment/people-to-peop le-communication-preventing-resolving-harassment-healthy-work-en vironment.html (accessed 4 November 2019).

19. Stadler P. Mobbing am Arbeitsplatz - Ursachen, Folgen sowie Interventions- und Präventionsstrategien. Retrieved from: Retrieved from: http://www.forschungsnetzwerk.at/downloadpub/ Mobbing_am_Arbeitsplatz_stadler.pdf (accessed 3 November 2019).

20. Toytok E. H. (2017) Perception of Mobbing by Teachers and Organizational Depression: A Correlational Model Study Universal Journal of Educational Research, 5(12A): 168-175.

21. Zapf D. (1999) Mobbing in Organisationen - "Uberblick zum Stand der Forschung. Zeitschrift fur Arbeits- und Organisationspsychologie, 43, 1-25.

22. Vveinhardt J. (2010) The diagnostics of mobbing as discrimination in employee relations aiming to improve the organizational climate in Lithuanian organizations. Management 
theory and studies for rural business and infrastructure development. 21 (2), 173-184.

Information about the author: Zinoviia Karpenko,

Grand $\mathrm{PhD}$ in Psychological Sciences, Full Professor, Professor at the Department of Social Psychology and Developmental Psychology, Vasyl Stefanyk PreCarpathian National University 57, Shevchenko str., Ivano-Frankivsk, 76025, Ukraine 


\section{FEATURES OF UNDERSTANDING THE HUMAN MENTAL DEVELOPMENT IN THE VIEWS OF THE REPRESENTATIVES OF THE SCHOOL OF PHILOSOPHY OF PSYCHOLOGY OF THE LATE XIX - EARLY XX CENTURY}

\section{Oksana Melnyk}

\section{INTRODUCTION}

Approaching the analysis of the world around us, we inevitably meet with complexes of phenomena that become understandable only when they are regarded as the result of development. For a long time there was a debate in psychological theory that what exactly in every studied fact need to be designated as development.

The development issue was developed in psychology too specifically, in terms of gaining experience, and the latter at the turn of the XIX - XX centuries tried to interpret not broadly biologically, but mechanically. Philosophy of psychology of the late XIX-beg. of the XX century, unlike other types, approached the issue of mental development, trying to reveal the peculiarities of this development, open general laws of mental development.

At the same time, according to representatives of philosophy of psychology, in no case should we forget that the object of psychological research is usually an adult, a creature that stands on the development ladder of a rather late stage. At the same time, a human is considered from three points of view: 1) compared to animals, 2) as a representative of a quite differentiated culture, 3) an adult compared to a child.

Often in the scientific sphere we can observe fundamentally contrary viewpoints of scientists on a certain issue during a certain historical period. The development of ideas about the nature of human psyche is not an exception. In the late 19th century, were formed two opposite psychologies, one of which was accused of failing to 
recognize the actual uniqueness of the human psyche, brings a human to the level of animal existence; the second direction was accused of losing in its emphasis the unique principles and requirements of science. In such accents, according to V.A. Romenets, there was historically limited truth ${ }^{1}$.

In the 19th century, a conceptual, philosophical approach to solving the issue of methodological foundationin of the formation of the subject of psychology begins to develop actively. It is the philosophical direction that becomes leading in the creation of psychological knowledge by teachers of the psychology course, scientists at the Kiev University of St. Volodymyr since its opening in 1834.

The specificity and uniqueness of psychological science is determined by representatives of the Kyiv School of Philosophy of psychology in its object, subject and objectives and possibilities of using the acquired knowledge, which it produces. There is a rather serious emphasis on the importance of psychological knowledge for the clerisy, public figures and those who have the desire and intention to influence public affairs and people 's lives, to create knowledge in general. At the end of the XIX - beg. of the XX century psychology of representatives of the Kyiv School of Philosophy of psychology is recognized as a science that studies psychical or mental phenomena and laws of psychical or mental life ${ }^{2}$. Thoughts, feelings, high ground decisions, mental states, conscious states - to see, feel, experience, come to any decision belong to the mental phenomena. At the end of the XIX - beg. of the XX century psychology of representatives of the Kyiv School of Philosophy of psychology is recognized as a science that studies psychical or mental phenomena and laws of psychical or mental life. Thoughts, feelings, high ground decisions, mental states, conscious states - to see, feel, experience, come to any decision belong to the mental phenomena. G.I. Chelpanov is convinced that the

1. P. RomenetsV.A. (2005). Istoriy psihologii. [History of psychology]. T. I. Kiev: Libid. (in Ukrainian). P.47.

${ }^{2}$ Zenkovskiy V.V., Sikorskiy I.A., Chelpanov G.I. 
description of mental phenomena and their integration, in case of similarity, allows to combine these phenomena into one common class. Mental phenomena are recognized as quite complex phenomena and in order to determine their nature it is necessary to carry out mental operation of decomposition into constituent parts or to cause analysis of them For example, "contemplation of any tragedy causes a complex mental state. To reveal exactly what thoughts and feelings accompany this state means the analysis of this state itself",3. And because of psyche, as G. Chelpanov convinced, it becomes possible to develop any mental states of a person ${ }^{4}$.

At the end of the XIX century, representatives of the Kyiv School of Philosophy of psychology began to use actively the word "psyche" instead of the word "soul." It can be explained quite simply. The soul is an invisible thing that cannot be directly observed and measured. And psychology, according to scientists, is a clear, serious and accurate science. Therefore, it was decided to study something that could both be observed and measured. And that is why during this period in the domestic psychological science there is a replacement in the designation relative to the subject of psychological science. The concept of "soul" and the concept of "psyche" were recognized as identical de facto, but were not resulted or separated from each other.

One of the key ideas about the human psyche of the representatives of the Kyiv School of Philosophy of psychology of the late XIX - beg. of the XX century turns out to be an idea for its development. Scientists emphasize that all phenomena of the surrounding world are in continuous movement, alternating opposite states, and stopping movement means stopping being. Scientists consider in general the whole dynamics of mental life of a person from these positions.

${ }^{3}$ RomenetsV.A. (2005). Istoriy psihologii. [History of psychology]. T. I. Kiev: Libid. (in Ukrainian). P. 6

${ }^{4}$ Chelpanov G.I. (1915). Chelpanov G.I. (1915). Ychebnik po psihologii (dly gimnaziy I ychilich)[Textbook of Psychology (for gymnasiums and self-education)]. Moscow: V.V. Dumnov. ( in Russian). 


\section{Understanding of the origin of psyche and the mental development of philosophy of psychology of the late XIX -early XX century}

With the emergence and adoption of the evolutionary hypothesis by the scientific community, animal psyche becomes one of the mandatory sections in the study of psychological science. It was believed that the study of animal psyche, simpler in its structure may contribute to the study of human psyche more complex in its structure.

In the domestic philosopho-psychological idea of the late XIX early XX century was believed that where there is no psyche and mental phenomena, the simplest event in life is the usual chemical and physical properties of protoplasm, and above them is something more complex - geotropism and heliotropism, which are characteristic for plants and animals. Geotropism is defined as the ability of plant organs to grow in a certain direction towards to the center of the earth, and heliotropism means the ability of plants to take a certain position under the influence of the sun. The phenomenon is based not on any involvement of the nervous system, but on simpler physiological phenomena. "For example, an grow of snowball," writes the representative of the Kyiv School of Philosophy of psychology, "according to the down movement or like spreading the process of contraction in muscle fiber if this process has begun anywhere in the fiber",5.

With the appearance of nervous tissue in the body of the animal occur the reflecting acts. I. Sikorskyi understands reflex as "machinelike act, always ready for action and similar to, for example, an electric call that rings continuously as soon as the current is made by pressing a button"6. The professor also calls the reflex "the favorite apparatus of wildlife: reflex devices are scattered in the living body by thousands and are easily, quickly and accurately driven by irritation,

${ }^{5}$ Sikorskiy I.A. (1909). Nachatki psihologii. [The beginnings of psychology]. Kiev: S.V. Kulzhenko. (in Ukrainian). P. 18

${ }^{6}$ Sikorskiy I.A. (1909). Nachatki psihologii. [The beginnings of psychology]. Kiev: S.V. Kulzhenko. (in Ukrainian). P.18 
as, for example, eyelid flashes or closes by reflex as soon as a small object touches the eye or eyelashes", In general, many well-known acts are reflexes, such as swallowing, sneezing, and the like. Less common but such that play an important role are automatic acts, that is movements caused by direct irritation of the nervous cell, for example, lack of solid, liquid or gaseous food in the cell (hunger, thirst, apnoea, etc.). Instinct composed of a series of automatic and reflex irritations is recognized more complex and more diverse than reflex. But mental act is recognized as the highest. If between sensitive and motile nerve cells there is a cell in which impressions (memory cell) are stored and reflecting excitation will pass through the sensitive cell and memory cell, and then the final effect of movement will depend not only on irritation at the moment (perception), but also on those memories that will be caused. And it is the simplest combination of impressions that take place in the present with impressions that were in the past, which is the essence of mental act: it provides opportunities to join impressions of the past time to this perception - and thus expands the life experience itself. So, orienting responses, reflexes, instincts, perceptions, and memories inosculating together constitute a complex organ of mental life in which physical, physiological, and mental are united for the purposes of life.

In order to trace the main stages of mental evolution I. Sikorskyi proposes to focus only on those animals, which already have a considerable degree of expression of various versions of the psychic model.

People belong to the worm, the professor notes, as a creature that stands at a rather low stage of mental development. Worms cannot protect their lives, do not understand the danger and do not escape it. The reason for this phenomenon the representative of the Kyiv School of Philosophy of psychology considers that worms have no other senses than tactile perception. "The worm," the professor writes, "feels the outside world to the touch and starts the living motion only when

${ }^{7}$ Sikorskiy I.A. (1909). Nachatki psihologii. [The beginnings of psychology]. Kiev: S.V. Kulzhenko. (in Ukrainian). P. 18-19 
anything directly touches its skin. Having neither an eye nor an ear, the worm is absolutely deprived of the means to feel the outside world from a distance and to understand the proximity of danger" ${ }^{\prime 8}$. It follows that the worm can be easily caught, whereas the ant and butterfly escape and are eluded the grasp. But on the other hand ants have five senses, but use only sense of smell. Ants have all those external effects that are perceived by higher animals as well. With its untiring activity, the ant attracts special human attention. The unusual instincts that the ant has developed towards the arrangement of dwellings and the organization of public life deserve attention, I. Sikorskiy believes. Between insects, the ant has the largest brain in relation to the size of its body. "The ant is deservedly," writes the professor, "given the name "mental atom", as it is first who has the soul with all its main properties, that are, five senses, complex instincts, one feeling (anger) and extremely mobile activity, which is based on a colossal conversion of potential energy into kinetic energy, which in such sizes, in the

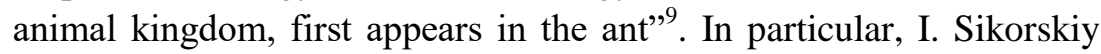
gives observations on the lifestyle and mental qualities of the ant of the English scientist John Lebbock (1834-1913), which showed that the ant has a short memory, which lasts no more than a few days, after which it forgets what it learned. Here, says Ivan Oleksiiovych, lies the reason for the extreme limitation of individual mental development of ant and other animals, which have short-term memory. Having a memory of the senses, the ant actually enjoys almost only one sense of smell, which plays a primary role for it: the ant determines the way, searches for food, searches for propupa with the sense of smell. Ants do not know each other personally, as personal familiarity is mainly based on visual impressions, and these impressions of ants are weak, and they distinguish the occupants of their nest from "strangers" by smell. Ant has a sense of anger for strangers and a sense of

${ }^{8}$ Sikorskiy I.A. (1909). Nachatki psihologii. [The beginnings of psychology]. Kiev: S.V. Kulzhenko. (in Ukrainian). P. 20

${ }^{9}$ Sikorskiy I.A. (1909). Nachatki psihologii. [The beginnings of psychology]. Kiev: S.V. Kulzhenko. (in Ukrainian). P. 21 
compassion for its own counterparts. But bees, which also have all senses, use not only smell, but also sense of sight, however, do not know each other personally and distinguish self from other with the help sense of smell too. In flights, movements, the bee enjoys sense of sight, visual representations and visual memory. It notices some bushes, flowers, trees and for them remembers the path to the hive and back. "But it also enjoys," writes I.O. Sikorskiy, "and the so-called "direction sense" that is, the memory of movements from the original point, and in case of assignment from the hive, bees, if they are released from different points away from the hive, each returns in a straight line to the hive. This ability to properly navigate is inherent in all animals in general, even those who are below" "10. At the same time, the professor notes, that the limited mind of the bee, as well as the mind of the ant, turns out from the fact that the bee is not available the ability to personally meet their bees on the hive, there is only a total difference self from other, controlled by sense of smell. For example, if a bee is deprived of its sense of smell, fumigate with smoke, or sprayed with any other aromatic substance, the bee will lose its sense of smell for a few hours or days, and then it becomes possible to combine two swarms, without risk of collision between them, and in a few days they will already consider themselves "friends".

The significant mental development of fish is found out from the fact that fish can be trained, giving it lessons of impressions, for example, to call to feed under sound. In this case a sound from food and food communicate in one general chain of memory in mind of fish, and the first member of this chain as a signal, causes the subsequent number, that is idea of food, of the place of delivery of food and of the direction of the movement to food. "In training fish to swim for food by sound," writes the professor, "we meet with a new mental phenomenon - individual mental experience and development. This phenomenon in such sizes with such expressiveness is first found

10 Ibid Sikorskiy I.A. (1909). Nachatki psihologii. [The beginnings of psychology]. Kiev: S.V. Kulzhenko. (in Ukrainian). P. 22 
in the animal kingdom - in a class of fish" ". This phenomenon becomes possible, according to I. Sikorskyi, thanks to the existence of conception of a large brain in fish - a special organ of mental functions, which allows individual experience and development.

According to the views of I. Sikorskyi birds have all senses even in the embryon- everything that is intrinsic to man. In particular, their memory has characteristics of long-term (up to 3 years). And this fact the professor recognizes as a significant step in mental development, as with the help of this it is possible to accumulate personal experience and, thus, to expand and accelerate the course of individual development.

The professor argues that birds have developed aesthetic and moral feelings that provide birds with a huge boost to the mental process. "The aesthetic feeling of birds," writes Ivan Oleksiiovych, "is reflected in the fact that they love colors, admire them, appreciate each other; in addition, they also love singing"12. I. Sikorskiy is convinced that the development of aesthetic feeling is the most important biological event during the evolution of the animal world. Aesthetic feeling not only determines further progress, but also serves as a significant indicator of improvement of external organization. Aesthetic feeling indicates the existence of physiological energy surpluses, which is spent not only on external work, but also on improvement of spiritual organization.It is through the development of moral feeling of birds that they have a lasting family life.

Mammals already have the ability to remember their impressions and not forget them throughout their lives. The life expectancy of the elephant is quite significant among other mammals. Under favourable conditions, the elephant lives to the age of 70. The elephant has long-term and accurate memory; it recognizes a man as his leader even after decades. "Like bulls," the professor writes, "the

${ }^{11}$ Sikorskiy I.A. (1909). Nachatki psihologii. [The beginnings of psychology]. Kiev: S.V. Kulzhenko. (in Ukrainian). P. 23

12 Sikorskiy I.A. (1909). Nachatki psihologii. [The beginnings of psychology]. Kiev: S.V. Kulzhenko. (in Ukrainian). P. 23 
elephant has higher feelings. An elephant can revenge if it gets annoyed by injustice. But he also can be generous, that first appears in the world of animals. For the first time we meet true love at the elephant: the elephant goes to captivity for captive children, which do not do other animals, even monkeys, who put the personal benefit above altruism"13. Observation data of elephants prove that they have developed patience and meekness, and the elephant approaches the dog by its gentle feelings, and by mind - to monkeys.

I. Sikorskyi reports that the $d o g$ occupies almost the first place in the classification of animals in relation to the development of higher feelings. Its loyalty to the master is set by people as an example. The dog has a sense of guilt, but has no sense of shame. If the sense of guilt is a precursor to shame,the dog is superior to almost all animals in this respect. Dog is the only animal a man has brought closer to himself as a friend.

Having a brain equal to the third part of the human brain, or equal to the weight of the brain of a newborn child, the monkey remains, from the point of view of man, according to the professor, a child, a jerk, despite lightning-fast mental manifestations sometimes. The monkey is characterized by special interest and copying. The feelings of monkeys, especially the feeling of sympathy, are developed very subtly and is manifested in the care and love for their children. Depth of feeling of the suffering monkey is quite significant. I. Sikorskyi calls the mind the strongest aspect of the monkeys` psyche, and the will considers weak, as the monkey cannot control itself; the behavior of monkeys is very active, fun, mobile and does not have the self-control necessary for mental development.

The first thing the professor points out in describing the features of human psyche development is the size of the brain: it is the largest compared to all animals and is very different from them by its mental qualities. And although this difference between human and animal psyche is obvious, according to I. Sikorskyi it was not scientifically

${ }^{13}$ Sikorskiy I.A. (1909). Nachatki psihologii. [The beginnings of psychology]. Kiev: S.V. Kulzhenko. (in Ukrainian). P. 24 
formulated at the time, and therefore animal psyche was too overestimated, then put at too low level. The essence of this difference is shown by the professor by example: "Spider builds its spider net subtly and very properly, and it seems that with this experience it is easy to go on in the system of constructions. Or nightingale: it sings so artistically that man admires its singing. The dog shows superior qualities, such as loyalty unto death, responsibility, affection, seemingly this is enough for further significant improvement. Meanwhile, reality shows a completely different thing: the spider can do nothing but its traditional net, the nightingale can sing nothing more, except the only aria, finally, the dog, showing high feelings, at the same time is deprived of a sense of shame, and does not even have germs of this feeling, and the man calls cynicism (by the nameof the $\mathrm{dog}$ ) the manifestation of severe forms of effrontery in the human race not without reason"14. But the person has no such mental narrowness, convinced I. Sikorskyi, "having studied one song, he can study and sing a dozen and hundreds of other songs; able to inweave one net, he can inweave many other nets; having one feeling is not not lacking in others" ". The professor sees the essence of this wide difference between the two psychologies - human psychology and animal psychology in that animals have not psyche, but separate elements of it. "The soul of animals is an artistic music box," the professor writes, "which can only play one aria if it is turned over - to give a boost from the outside. The soul of man is organized on similarity of a musical box with an infinity of keys, while with a wide opportunity to vary keys and receive innumerable quantity of plays, elegant works, unseen subtle combinations through various rearrangements"16. In cases of juvenilism of mental abilities of a person, for example, of an idiot, his mental model resembles features of an animal psyche, for example,

${ }^{14}$ Sikorskiy I.A. (1909). Nachatki psihologii. [The beginnings of psychology]. Kiev: S.V. Kulzhenko. (in Ukrainian). P. 25

${ }^{15}$ Sikorskiy I.A. (1909). Nachatki psihologii. [The beginnings of psychology]. Kiev: S.V. Kulzhenko. (in Ukrainian). P. 25

${ }^{16}$ Sikorskiy I.A. (1909). Nachatki psihologii. [The beginnings of psychology]. Kiev: S.V. Kulzhenko. (in Ukrainian). P. 25 
there are so-called idiots-geniuses who are able to draw a bird or only the head of a bird artistically, but further this cannot take a step. The psyche of animals is strong only within instinct (food, sleep, selfprotection), where the excitatory tendency of sensitive and mobile mechanisms is almost as large as that of humans, and where perception of impressions and their recognition takes place quickly, clearly, and as quickly and accurately followed by a movable reaction; but beyond instincts, the nervous system remains almost undeveloped. According to I. Sikorskyi all segments of the nervous system of a man, included in the chain of instincts, like those that do not included, are developed equally enough and completely. Long-term memory (for life), subtle movable associative mechanism, all kinds of feelings is the principle of human psyche. "If you take away a person "s shame," writes a representative of the Kyiv School of Philosophy of psychology - or any other feeling - he will turn into a moral idiot into an animal. And only the completeness and development of all sides and all units of the psyche ensure his humanity " 17 .

\section{Development and change in human mental development by age}

The greatest masterminds of the past - Aristotle and Plato, Spinoza and Kant - were once children and their comprehensive world psyche developed slowly, gradually taking the usual path of helpless infant thinking. This path is rich in supreme interest and is able to excite deep feelings in the observer-psychologist.

The psyche of the newborn develops constantly, turns into the psyche of the child; psyche of a child turns into psyche of a young man by means of colossal tension of forces, then becomes psyche of an adult person, and in old age - psyche of a person in age.

Scientists divide the whole cycle of mental evolution of man in philosophical psychology of the late XIX - early XX century as follows:

${ }^{17}$ Sikorskiy I.A. (1909). Nachatki psihologii. [The beginnings of psychology]. Kiev: S.V. Kulzhenko. (in Ukrainian). P. 26 
I. Psyche at the age of the first childhood (from birth to 7 years).

II. Psyche at the age of second childhood (from 7 to 14 years).

III. Psyche of young age (from 14 to 22 years).

IV. Psyche of mature age of a person (from 26 to 30 years).

$\mathrm{V}$. The psyche of the ageing period (45-55).

Psyche and its development in the first age of childhood. The age of first childhood is divided into the following periods where each has the main characteristics and way of transition to the following higher degree of mental life:

1. Newborn psyche, or infant psyche.

2. First three months after birth.

3. From the fourth to the tenth months of life.

4. The end of the first and the beginning of the second year of life.

5. From the second to the sixth year of life.

It is proposed to start consideration of the newborn psyche in parallel with two series of phenomena: external organization and mental competences. First of all, the attention of the psychologist should be focused on the face of the child and on all his appearance. If no defects and handicaps are noticed in external development, all this, according to the representatives of the School of Philosophy of psychology of the late XIX - early XX century, presages the normal course of mental development of the child. At the same time, children with some physical disabilities are not always deprived of the possibility of normal mental development.

In the first days after birth, only nerve centers, which are responsible for reflex actions, are developed in the child. However, the infant, as the adult, has phenomena of a purely physiological nature in which no mental content is noticed, but there are also phenomena that bear absolutely mental reflection. Also the presence of intermediate type phenomena, which can be classified as either physiological or mental, is recognized in philosophical psychology, but during this period this issue has not been solved.

Physiological phenomena include the response of external organs to irritation (e.g. tickling or tingling). The child closes his 
eyelids, sneezes or coughs if he gets anything into the airways. Newborns also have much more complex types of movements and phenomena, where the activities of those complex mechanisms that regulate themselves and act automatically are observed. These include the regulatory mechanisms of the heart, the mechanisms that regulate body temperature and make the breathing process possible.

In the first days from birth, the child already has the ability to taste and olfactic perception - the ability to taste and olfactory cognition; the infant pays attention to these perceptions, that is, focuses on them and holds them by connecting bulesis. The infant has the ability to remember taste and olfactory impressions and distinguish them. But at this time, the child has no idea of sound or light. Regarding feelings, a newborn child is deprived of any specific feelings. His psyche is only accessible by states of pleasure and displeasure and a sense of pleasant and unpleasant in his simplest undeveloped features. Such a feeling or mental state is also characteristic of the psyche of an adult, where it is used along with other absolutely clear, complete and certain states of psyche and mood. For a newborn child, the presence of two opposite common conditions - pleasant and unpleasant - make up the only possible form of feeling.

In the first three months of his life, the child learns to hear, see and touch. There is an active process of learning of the child's own senses. The direct organ for the perception of his body is a myriad of sensual centers scattered across the skin, mucous membranes, muscles and internal organs. Because of nerves there are billions of impressions every second and they continue their way to the cerebral cortex, that is, the sphere of body sensations or the tactile sphere. The development of visual perception and attention can provide a clear explanation of the work of complex processes of a biologically and psychological nature that occur in the child 's body during the first three months after birth. Finding out this question is absolutely important not only for the psychology of childhood, but also for general psychology. The core of the issue is that the child does not know how to control eye muscles in the first days after birth and an 
important part of the visual apparatus occupies a completely random position in relation to visual objects every minute. The child must make constant efforts, continuous stresses to adapt his visual apparatus and learn to use his vision tool.

The representative of the Kyiv School of Philosophy of psychology I. O. Sikorskyi believes that for the foundations of mental development of the child hearing is more important than vision. And this can be seen, according to I. O. Sikorskyi, by watching blind and deaf children. "A deaf child," writes the professor, "develops spiritually to a much lesser extent than a blind child, and this can be noticed very early, already in the first months of life" 18 . At the same time, development of hearing in the first days after birth does not occur in all children at the same rate. But it can be considered that on the second or third week of life almost all children begin to hear. In confirmation of that, it is possible to view sudden closing of the eyelids with any strong sound. With further development the child flashes the handles in response to a strong or sudden sound. If the sound is strong and lasting, the child gets worked up that is expressed by fidgets and then begins to cry. By the end of the second, and more often before the beginning or even the end of the third month, the child turns on the sound and holds his ear towards the sound. The child also begins to listen to sounds from movements of his own body, breathing and even beating his heart.

By the end of the first month from birth, the first specific feelings become visible - feelings of suddenness. Although this feeling does not differ by clear content and certain well-being even of an adult person, however, due to his unusual objective clarity of the child I.O. Sikorskyi gives him the importance of an independent nervous-mental state, which should distinguish from other feelings that develop later - surprise and fear.

The sense of suddenness lies in the external stop of mental and some nervous processes, which for a short time - up to half a minute -

18 Sikorskiy I.A. (2009). Duha rebenka. [Baby Soul]. Moscow: Astrel. (in Russian). P. 59 
suddenly last, as if all nervous acts had received a reverse or a boost. In its simplest forms, a sense of suddenness appears to be a purely physiological process; in its higher forms it is also filled with physical elements. The delay of nerve acts in a state of suddenness can sometimes precede eye flashing, handle lifting, and general tremor. The feeling of suddenness for the child is caused by strong sound impressions already in the first week after birth, as well as under the influence of other irritations received from any organ of feelings. A sense of suddenness borders between pleasant and unpleasant feelings and can move into other mental states, increasing their strength and tension.

The period from the fourth to the tenth month of life plays an important role in the mental development, because exactly at this age begins the highest mental activity. New at the beginning of the fourth month is the fact of recognition of visual and auditory impressions. Recognition of the child is a active joy, energy and a long concentration. Mental life becomes conscious, takes a new direction due to the emergence of consciousness and will, has other goals, takes new external forms, and recognition becomes an effective act and indicates the emergence of associations of the child, that is, the ability to associate some mental acts with others and thus establish the continuity of their sequence and course.

Thus, the beginning of the fourth month of a child 's life is characterized by the following significant signs:

1) is formed the ability to concentrate visual perception;

2) ability to recognize previous impressions (visual and auditory)

3) expression of emotion of joy in causal connection in act of recognition;

4) the desire to find new impressions and the combination and bonding of the obtained impressions into thought rows and chains;

5) ability to generalize, to form thought formulas, to transform unconscious associations in the process of thinking;

6) the main feature of this period constitutes the development of associations. 
The next period of mental development covers the end of the first year and the beginning of the second year. During this period of life of the child there is development of one of the highest mental functions - speech development. When the thoughts of the child, mental acts, memory are already at a certain level of development the word begins to become a need. Speech development begins after the child has achieved some success in mental development and when his will is somewhat stronger.

Usually a child starts talking before walking. And therefore, this fact alone points to the importance of speech in a number of processes of mental development, especially since speech movements belong to the category of the most complex movements in the human body. The essence of speech and its complexity lies in complex nervous-mental work, which is hidden under the sounds of words. There is no speech in the presence of severe cognitive impairments. Speech development from philosopho-psychological positions is divided into three periods: 1) study of sounds (4-6 months), 2) understanding of words (10-12 months) and 3) pronunciation of words (after 12 months).

The period from the second to the sixth year of life is characterized by the even development of all aspects of mental life with the development of speech inclusive. From an anatomical point of view, this period is similar to previous periods, but differs from the following period (second childhood) in that anatomical development of the brain continues during it. The essential sign of this period is the integration of all processes of feeling, thought and will into a whole unified human personality. During this period it is already possible to talk about the temperament of the new personality, which is determined, as well as about possible abilities. Feelings during this period are nonsustained and weak. These feelings may seem strong, but they are actually weak and shallow, at least early in this age period. Their perceived strength depends on the fact that they are not subject to the deterrent influence of will, at this time is very weak like thought. Representatives of philosophical psychology notice two trends in all further development of the child - constant development of feelings and constant suppression of them by growing will. It is 
about oppression, not destruction, because in reality feelings that are constrained by will do not disappear, but turn - then into complex and high feelings, then into deeper ones. The weakness of the child ' $\mathrm{s}$ feelings is expressed in the fact that children quickly forget the experience and move from one mood to another. The feeling that is characteristic only of man - shame - develops not earlier than the third year of infants' lives; the accusativeness lies in the relationship to the sense of shame and precedes it in development time. The accusativeness manifests itself very early and in a mature and serious form. The development of such higher feelings of the child as aesthetic, intellectual and moral also takes place in this age period. Close to moral feeling in philosophical psychology of the late XIX early XX century is considered a religious feeling. This feeling refers to the most natural feeling of the child and to neglect the development of this feeling is equivalent to not recognizing the natural laws of human mental development.

The development of feelings precedes the development of thinking processes and will, and by the end of the period this difference is kind of increasing. Under such conditions, children particularly need support and care. The development of feelings between the ages of 3 and 5 gives children special psychological features: they are gentle, sensitive, bruise, but at the same time sensual and weeping, exposed to short-term and even often deep subjectivity. All this is signs of feeling that is rapidly developing. With the end of this period, the development of feeling is already much slower. This period may delay (moving to 4-6 years), then comes much earlier, for example, earlier than 2 years of life. Children's feelings in accidents develop especially rapidly.

Regarding mental abilities in the period under consideration, philosophers-psychologists point to their weakness and fragmentarity of thinking. Children's perceptions, concepts and thoughts are fragmented and filled with gaps that depend on lack of experience; these are only individual episodes, far from becoming "the whole". At this age, it is still difficult for children to absorb and notice things which many times were before them. For this purpose it is necessary to 
train arbitrary attention, and it is not as simple task as seems and not only for children, but also for adults. The importance for the mental development of the child does not cease to play also external impressions of the organs of vision and hearing.

The level and course of mental development in the period from 2 to 6 years from birth are indicated by the peculiarities of the manifestation of will processes. The will of children is rather weak in this period. It is expressed first of all in inability of the child to hold back tears, laughter, mischief, anger, shyness, rage and even (at the age of 2-3 years) to control a bladder. The latter may even serve as a measure of child's will development: early developed tidiness in the toilet is a good sign; on the contrary, the inability to enforce it indicates a weakness of will. The weakness of the child 's will is also evident in the humble and unconditional obedience of the child to the strongly expressed will of the adult. The development of will is perceived: 1) in the agility of hand movement, 2) in the expressiveness of language, 3) in proper walking, and 4) in developed attention. Will acts as a certain "anchor," the last experience of thought and therefore develops somewhat later than intelligence.

The development of the child 's personality takes place through personal efforts and intensenesses and the emergence of selfcomprehension. But for a long time the child does not realize himself, has no idea about himself and does not remember himself. Gradually, however, step by step, the child begins to distinguish and separate the entire outside world from himself. It is from the moment of the onset of self-comprehension, according to the views of representatives of philosophy of psychology is formed a personality and now "selfimage" of the child becomes the core of consciousness, has its present and past and lives a happy present, before which the future is unnoticeably prepared.

In the second half of the period under review of the child 's life (4-6 years) happens growing and personality development, and the child is gradually knowing himself and the outside world. The most important auxiliary tool in this knowledge, both of himself and of the outside world, now becomes the word. The exchange of opinions with 
others and the translation of his thoughts and feelings into words gradually deepens knowledge, and makes the inner world of the child, which is revealed, more and more clear and tangible to him. This inner world is subjective, which cannot be seen by an outsider, thanks to words becomes heard, understandable, tangible and objective. Philosophers-psychologists are convinced that communication with adults, life with them is the main source of mental development of children at this stage of life, when the use of methods of scientific development of higher mental manifestations is not available yet.

Developmental abnormalities of mental manifestations are considered to be: a) the imbalanced development of feeling, mind and will, $b$ ) the prevalence of perceptions over thinking, and c) the child 's pamperedness and a total absence of authority. Signs of mental development are normally considered to be: a) fun and vitality of the child, calm and sufficient sleep and appetite, rare and short tears, b) capture of the child by the game, $c$ ) daily notable cerebral successes (new words in the language, new items for the game and new objects of attention), d) activity, mobility of the child emerging from intellectual requirements, and e) independence of the child, which early manifests itself in games and pursuit.

The next period of mental development of philosophy of psychology is psyche at the age of the second childhood (from 7 to 14 years). Entering the period of the adolescence, the child has all basic mental abilities: feelings, attention, ability to arbitrary attention, will features, memory, certain mental abilities. But the development of mental competences of everyone has its own peculiarities and a certain unevenness in their development. From a psychological point of view, a child of this age can be equated with an adult in qualitative terms, but in quantitative terms there is still a significant difference.

In the age period of 7-14 years, the developed side of mental life is feelings; will processes and mental processes are somewhat inferior. Mental development concerns mainly the last two manifestations of mental development. And although children of this period already have an excellent memory, it turns out to be excellent only for casual perceptions and associations. As for arbitrary attention, it is 
considerably weaker. The teenager should engage in long-term exercises for getting necessary level of arbitrary memory (i.e. associations and reproductions). Therefore, systematic mental work is difficult to some extent, but for simpler tasks, both memory and automatic attention are sufficiently developed.

The main features of personality character between 7 and 14 years are so pronounced that in some cases it is possible to determine character. Mental states at this age are not such that autonomy and independence of actions are impossible, children of this age willing or not obey others. In most cases, at the end of this period, mental conditions change very significantly, and in these cases, according to the opinion of representatives of philosophy of psychology, the existence of a transition or intermediate period should be allowed.

This transition period (12-15 years) corresponds to the last years of the adolescence and stands on the border line of youth. At this age, there are physical and moral changes that predate youth. Physical changes consist in accelerated body growth and the emergence of the first visible sexual signs, the display of courage and femininity. The psychological characteristics of transition age are as follows.

During the development of feelings, become visible fluctuations or stagnation caused by the peculiarities of psychophysiological development. Mental capacities continue to develop constantly, however, due to fluctuations, the sense of mental work is less successful. Mental abilities at the beginning of this period are characterized by a weak ability to compare and generalize, to assess and criticize; they are more prone to individual work and to specific, small mental exercises. The will, as opposed to other manifestations of psyche, begins to grow strongly, continuously successfully increase. However, this build-up does not yet create a character, as character is due to the general development of feeling and will. At this age it is found meaningless child heroism, in a tendency to fabulous feats, where large and funny, mature and child are inextricably connected to each other. 
The next period in human mental development according to philosopho-psychological tradition is youth. Youth begins at the age of about 15, at the age of 18-20 years moves to mature youth and then, to mature age.

The development of the psyche during youth coincides with quite significant processes of physical development, so that both cycles of phenomena are in some ratio and connection, at least in time. The period of youth from a philosopho-psychological point of view is characterized by the excitatory tendency of all mental manifestations feelings, mind and will. This excitatory tendency is a deep organic process that is never repeated in life again. This is the important psychological and educational effect of youth age.

With the onset of youth, feelings become extremely deep, sincere, and perfectly pure. In youth, the will is rapidly strengthened and provides the mental structure with the character of determination, courage and independence. But the greatest changes are taking place in the thinking process. The main feature of mental development in youth is seen in the deep desire to highlight and unite all mental manifestations, to combine into one all impressions, which are stored in memory and to have a single whole world view, having reconciled all contradictions and solutions of all problems for himself. During this period, the question of mission is decided, and a plan for all subsequent life is drawn up. The changes that occur in mental development at this time bear the typical seal of the ideological process, so to speak, with broad plans and a brave flight of thought.

The correct course of mental development of youth manifests itself in restraint. Representatives of the Kyiv School of Philosophy of psychology I. Sikorskyi and Zenkovskyi note that life does not require young people to do business, providing an opportunity to develop, think about their mission, expand their outlook, create programs of life. Youth is mainly devoted to this: it is all in the future and lives hopes. The older generation acts until it is helped and replaced by mature youth "Like love," writes Ivan Oleksiiovych, "which has the power to change man, and all the processes taking place in the young soul leave an indelible mark in it, which becomes a living and vital 
beginning throughout person's later life. From that youth is dear to us as a period of great transformation of the soul, when everything exalted, strong and good fills it" $"$.

In order for this organic process to occur correctly during the youth period, according to philosophers-psychologists, continuous efforts are needed from a growing person to meet the needs of the psyche that are revealed. The actions taken to develop the psyche during this age period have a decisive impact on the following age periods of a person 's life.

The next period of human mental development is mature age. In the physical sense, this age begins with the end of growth of the body, at the age of about 26-30 years, but mental maturity, said representatives of philosophy of psychology, comes earlier at this age. Often, however, mental maturity is lagging behind, which is reflected in the lack of development of the will sphere of the person and from this lack of self-control, despite a sufficient level of development of mind and feeling.

Mature age is a period of human activity and is characterized by a desire to achieve life goals and objectives. "Activity and the implementation of tasks," the professor writes, "is a direct natural duty of a person at a mature age; at the same time, it is also a moral duty, according to the great principle that every tree which does not bear good fruit will be cut down and thrown into the fire" 20 . The formation of man as a person takes place directly in activity. Person's identity and his individual characteristics influence the very nature of activity and the way of carrying out life duty in mature age. So, the properly spent youth brings to mature age not only programs and plans, but also that reserve of energy and internal tension, insists Ivan Oleksiiovych, "which is the true grain of the future big tree" 21.

\footnotetext{
${ }^{19}$ Ibid. Sikorskiy I.A. (2009). Duha rebenka. [Baby Soul]. Moscow: Astrel. (in Russian). P. 145

${ }^{20}$ Ibid. Sikorskiy I.A. (2009). Duha rebenka. [Baby Soul]. Moscow: Astrel. (in Russian). P. 146

${ }^{21}$ Ibid. Sikorskiy I.A. (2009). Duha rebenka. [Baby Soul]. Moscow: Astrel. (in Russian). P. 147
} 
Mature age is the age of practical life, as opposed to the ideological life of youth. With the correct mental development, youth and maturity are as different from each other as the project and its execution are, or as the idea and its concrete implementation. However, the realization of specific tasks and individual goals of life is able to introduce, and sometimes introduces into a mental device some unilateralism, which is fixed by time and habit. Hence there is a kind of psyche specialization in a known direction with violation of its ideal completeness. Under such conditions, mental life could become unilateral and narrow down to a certain extent if not for the existence of moral adjustments. Such adjustments in philosophy of psychology recognize religion, science, family, social life and psychological difference of sex, because they contribute to the psyche the diversity, breadth and depth that supports mental completeness and integrity of man. Special immediate activity value is attached to the family with its interests, where the role of woman in the family is recognized as the leader. A woman 's psyche is recognized as much more flexible than a man 's. Thanks to the greater development of feelings, a woman always keeps more idealism and breadth in her psyche for old age, with signs of innocent childhood of perfect youth than a man. That is why a woman is largerimbued with the understanding of a young man who grows up, than a man, and is a natural link of two generations who are united in a family.

The main errors of mental development, according to the representatives of philosophy of psychology, which are most inherent for mature age, are the underdeveloped, weak will of men and the lack of tactile and subtle development of feelings of women. Under the above-mentioned conditions, a man becomes little active and unstable, and a woman is in danger of moral submission to the environment and routine, with a loss of ability to experience higher feelings and moral brilliance.

Periodization of human mental development in philosophy of psychology of the late XIX - early XX century concludes with an ageing period. In this period, between 45-55 years of age, begins a decline in the physical life of the body, reflected in a decrease in the 
size and dimensions of all organs of the body, including the brain. Such a change cannot but affect mental manifestations, at least in quantitative terms. In this sense, the psyche of a person of this period differs from the psyche of other age periods of life. "However, it is not necessary to think," writes Ivan Oleksiiovych, "that in the soul of the elder there are phenomena of mental decline and destruction of those outstanding beginnings, which we call the human heart, the human spirit. It happens to be that! But we will not stop on pathology or deviation; our task is to describe the natural course of mental evolution with age. Not only painful old age, but also improperly performed, inactive youth is full of mental gaps and shortcomings, but they are exceptional phenomena" 22 .

At the same time, despite some physical weakness of the nervous system and brain for the age period, the considered mental activity can be quite productive at tireless work and tension and activity of thinking processes, contributing to development and improvement of efficiency. I.O. Sikorskyi gives an example of direct correlation. "A study of the brain of Helmholts, Mentsel, etc., found that constant mental and moral tension protects brain tissue from destruction and maintains it in a state of physiological vitality. Everything in the body of such a hard-working person ages, all organs - heart, muscles, bones - atrophy, but the organ of thought brain - remains preserved, the hand of time does not touch it. It is a consolation for those approaching the deadline for human life. Let the body be destroyed - such are the laws of nature, but let man not leave clarity of mind, willpower and flame of the heart until the last minute of life" 23 . There are many examples of the life of great people in history, where such an achievement is presented, and the way to this is the continuous improvement of mental manifestations. Genius, I. Sikorskyi argues, means continuous work, where the latter with

22 Sikorskiy I.A. (2009). Duha rebenka. [Baby Soul]. Moscow: Astrel. (in Russian). P. 148

23 Sikorskiy I.A. (2009). Duha rebenka. [Baby Soul]. Moscow: Astrel. (in Russian). P. 149 
development and improvement of mental is not so much a gift of nature as a credit of personality.

The development of human psyche during old age reaches the highest degree. No age period compares with old age according to life experience and the moral development that man reaches at the end of his life. The further continues life in old age, the fewer remain those who were close and important, with whom the person became related and got closer. Understanding his extremity, which approaches every day, man increasingly seeks to live, to be necessary not only close to his family and friends. Old age should be full of unconditional love for people, because this attitude towards people, including the world around him, indicates that man in previous periods of life paid attention to his own development, improved his mental competences and higher feelings. And in general, as the representatives of the School of Philosophy of psychology of the late XIX - early XX century are certain, man of this period is an embodiment of wisdom and a model of pure and sublime concept of duty.

\section{CONCLUSIONS}

Mental development issues at the end of the XIX - beg. of the $\mathrm{XX}$ century in psychology occupies the main place in scientific search of representatives of the school of philosophy of psychology. Appear publications, books in which ideas of problems of human psyche development are presented. The works cover the facts of observations of children, their development of sensations, emotions, movements, will acts, speech, thinking and self-consciousness.

In the late XIX and early XX centuries were published many diaries of educated parents, in which they recorded the results of their observations of the mental development of their children in early and pre-school age.

From the late XIX century and in the early XX century, societies of child psychology began to be organized in different countries, and books from its general and special issues began to be published more often. In Germany, books were published by W. Shtern (1871-1938) on the mental development of children before 
the age of seven, on the development of speech, a mention in early childhood, and K. Hross (1916-1946) about children and animals. In France, A. Bine (1857-1911) initiated the study of mental development. At his school, were published a number of works about the peculiarities of the development of attention, memory, imagination, thinking, curiosity, aesthetic feelings and will of children, about their visual activities. He created the first tests of mental intelligence.

In England, were published books about methods of studying different aspects of mental development, about the characteristic features of childhood in its early stages (D. Selly). Psychological research not only of childhood, but also of youthful age developed in the United States (S. Holl). There was born the idea of creating a holistic science about the child (pedologia), which found its fans around the world for a while. However, attempts to implement this idea have proved ineffective due to the error of theoretical foundations and the lack of reliable data on various aspects of the child 's mental development. The latter was understood by the proponents of this idea as a biologically conditioned process. In contrast to the biological direction in the domestic school of philosophy of psychology of the late XIX and early XX centuries, the understanding of mental development was based on ideas about mental as a special substance.

\section{SUMMARY}

The presented results of the theoretical study reveal the peculiarities of understanding the idea of mental development of man in the philosopho-psychological tradition of the late XIX - beg. of the $\mathrm{XX}$ century. The material reveals characteristic features of mental development in different periods of human life. The mental development of a person was divided into the following periods: I) psyche at the age of the first childhood (from birth to 7 years): a) psyche of a newborn, or psyche of an infant, b) the first three months after birth; c) from the fourth to the tenth month of life, d) the end of the first and the beginning of the second year of life, and e) from the second to the sixth year of life, II) psyche at the age of the 
second childhood (from 7 to 14 years old), III) youth psyche (1422 years old), where there is a separate transition period (12-15), IV) the psyche of mature age of a person (26-30 years) and V) the psyche of the period of ageing (45-55 years).

\section{REFERENCES}

1. Zenkovskiy V.V. (1914). Problemu psihicheskoy pricheskoy prichinnosti. [Mental causation problems]. Kiev: Imperatorskiy Universitet Sv. Vladimira. (in Ukrainian).

2. RomenetsV.A. (2005). Istoriy psihologii. [History of psychology]. T. I. Kiev: Publishing "Libid". (in Ukrainian).

3. Sikorskiy I.A. (1909). Nachatki psihologii. [The beginnings of psychology]. Kiev: Publishing S.V. Kulzhenko. (in Ukrainian).

4. Sikorskiy I.A. (2009). Duha rebenka. [Baby Soul]. Moscow: Publishing “Astrel”. ( in Russian).

5. Chelpanov G.I. (1915). Ychebnik po psihologii (dly gimnaziy I ychilich). [Textbook of Psychology (for gymnasiums and self-education)]. Moscow: Publishing V.V. Dumnov. ( in Russian).

\section{Information about the author:}

Oksana Melnyk,

Candidate of Psychological Sciences,

Senior Research Associate,

Doctoral Student at the Department

of Developmental Psychology of the Faculty of Psychology,

Taras Shevchenko National University of Kyiv ORCID ID: orcid.org/0000-0002-8652-6833 
DOI https://doi.org/10.36059/978-966-397-161-2/97-116

\section{METHODS OF RESERCH OF EMOTIONAL INTELLIGENCE}

\section{Mariia Stasiuk}

\section{INTRODUCTION}

A concept "emotional intelligence" is one of the most investigated for the last decades in the psychology. Due to the publications of D.Goulman an emotional intelligence was rooted in researches of sociological professions. Indisputably, there is importance of emotional intelligence in professional cooperation in the field of "man-man". There are some researches about the sphere of cooperation a "man-technique" and the role of emotionality. It is important to mention that on the first place is a contact of man with a computer technique in the field of information technologies. However, the organization of activity in IT-sphere involves combination of different relation processes and formats. Development intensity of information technologies is after both complication from a technical side (in particular, wide prospects of creation and perfection of artificial intelligence) and expansion of cooperating with people, including those who do not known a specific "technical" language. Accordingly, the emotional component of cooperation will become more and more urgent.

\section{Evolution of views on emotional intelligence}

Interest in exploring the socio-emotional sphere of the psyche, and not only general intelligence and thinking, has grown among scientists since the beginning of the twentieth century. The very idea of the emotional intelligence existence was formed from the concept of social intelligence that was actively developed by such scientists as E. Thorndike (1920), J. Guilford (1967), and G. Eysenck (1995). Independently of each other they floated the idea that people differ in their ability to understand other people, capacity to manage them, and productivity in interpersonal relationships. 
The discovery of emotional intelligence is related to a study carried out by R. Thorndike in the 1920s. He for the first time singled out such component of general intelligence as social intelligence, that is, the ability to understand others and act or behave wisely toward others. R. Thorndike believes that test-measured intelligence is abstract, and that there are also mechanical and social intelligences. Later on mechanical intelligence has been called practical intelligence. Social intelligence is described by the author as the ability to succeed in interpersonal situations and to manage men and women, boys and girls, that is, to act wisely in human relationships ${ }^{1}$.

G. Gardner came very close to the modern concept of emotional intelligence. He put forward the idea of multifactorial intelligence, which includes two variants of personal intelligence - interpersonal and intrapersonal. Emotional abilities, in turn, act as the emotional component in both these spheres ${ }^{2}$.

G. Gardner supported the idea of multiple intelligence proposed by L. Thurstone and, in 1983, suggested the existence of seven different forms of intelligence besides the traditional verbal and logical-mathematical ones. According to G. Gardner, these intellectual features of a person cover both interpersonal and interpersonal abilities. The scientist identified the following forms of intelligence: spatial, musical, linguistic, logical-mathematical, body-kinesthetic, interpersonal and intrapersonal.

Interpersonal intelligence is interpreted by the scientist as "an access to one's own emotional life, one's affects and emotions: the ability to recognize feelings immediately, name them, translate them into symbolic codes, and use them as a vehicle for understanding and controlling one's behavior".

According to G. Gardner, intrapersonal emotional intelligence is the ability to observe and differentiate other people's feelings and to use this knowledge to predict behavior.

1 Thorndike R. Stanford-Binet Intelligence Scale: 4th edition (Technical Manual) / Thorndike, R., Hagen, E., and Sater. - Chicago: Riverside. - 1986

${ }^{2}$ Gardner H. Multiple intelligences. N.Y., 1993. 
One of the first publications on the developed model of emotional intelligence belongs to Peter Salovey and John Mayer ${ }^{3}$. It is also the most well-known in both psychological and management literature, and is theoretically and empirically developed model of emotional intelligence as an aptitude. The first version of this model was proposed by scientists in 1990 . They defined EI as the ability to detect one's own and others' feelings and emotions, to distinguish them and to use this information to direct one's actions".

The "early" model of emotional intelligence, proposed by P. Salovey and J. Mayer back in 1990, consisted of three types of abilities:

1) identification of emotions and their expression;

2) regulation of emotions;

3) the use of emotional information in the process of thinking.

The model was subsequently revised and supplemented with other cognitive functions and abilities. This revised version was based on the idea that emotions contain information about an individual's connection with other people and objects, that is, they actually "inform" the person about the nature of those relationships. Emotional intelligence in this model is seen as a hierarchical structure with consistent and interdependent levels. Analysis of the individual qualities involved in the processing of emotional information allowed the scientists to identify four components that are formed sequentially in the process of ontogeny:

1. Identification of emotions. It includes a number of related abilities - the perception of emotions (that is the ability to notice the mere existence of emotions), identification, adequate expression, distinguishing between true emotions and their imitation.

2. The use of emotions to increase the efficiency of thinking and activity. It includes the ability to use emotions to direct attention to important events, to evoke emotions that contribute to problem

3 Mayer J.D. Emotional intelligence: Popular or scientific psychology. [Electronic resource.] 2005. Mode of access: http://www.apa.org/monitor/sep99/ 
solving, to use mood swings as a tool for analyzing different views on a problem.

3. Understanding emotions. The ability to understand complexes of emotions, connections between emotions, changes from one emotion to another, reasons of emotions, verbal information about emotions.

4. Emotion management. The ability to control emotions, reduce the intensity of negative emotions, awareness of one's emotions, including unpleasant, the ability to solve emotionally charged problems without suppressing the associated negative emotions. It promotes personal growth and improvement of interpersonal relationships.

Emotional identification is a necessary basis for the further use of emotions in order to solve specific problems (Level 2). It is essential for understanding prior events that caused certain emotions or have resulted from them (Level 3). The ability to identify, understand and use emotions is necessary for emotional state self-regulation and for successful impact on the environment, that is, the regulation of own and others' emotions (Level 4). Thus, a high level of emotional intelligence provides that a person manages one's own emotions, perceives and governs them, does not suppress or displace "unwanted" emotions but regulates the expression of one or another emotion in each situation. Emotional intelligence begins with an awareness of one's own emotions, and only then is it possible to understand other people's emotions and the reasons that caused them.

Clinical physiologist Reuven Bar-On ${ }^{4}$ was one of the first who used the term EQ (emotional quotient) by analogy with IQ (intelligence quotient).

R. Bar-On understands emotional quotient as a set of noncognitive abilities, knowledge and skills that affect an individual's ability to meet environmental demands. R. Bar-On was the first one who tried to measure emotional intelligence. To do this, he tried to link the

${ }^{4}$ Bar-On R. The Bar “On Emotional Quotient Inventory (EQ” i): Technical Manual. Toronto: Multi "Health Systems, 1997 
degree of development of the emotional quotient with the overall quality of life. Actually, the questionnaire was first designed to test this concept. Gradually R. Bar-On developed a multifactorial approach to emotional intelligence in order to organize its quantification.

\section{Emotional intelligence as the sum of abilities according to Mayer and Salovey}

\begin{tabular}{|l|l|}
\hline \multicolumn{1}{|c|}{ Emotional intelligence } & \multicolumn{1}{c|}{ Emotional "stupidity" } \\
\hline $\begin{array}{l}\text { 1. the ability to perceive } \\
\text { emotions (to notice them) and to } \\
\text { express them adequately and } \\
\text { adaptively (emotional } \\
\text { perception and expression); }\end{array}$ & $\begin{array}{l}\text { lack of ability to notice emotions } \\
\text { (coldness), "indifference"; } \\
\text { inability to express emotions } \\
\text { adequately and adaptively; }\end{array}$ \\
\hline $\begin{array}{l}\text { 2. the ability to experience } \\
\text { (generate) feelings about } \\
\text { cognitive and other types of } \\
\text { activity (to enjoy the learning } \\
\text { new things - if there is a } \\
\text { motivation to learn; success in } \\
\text { the activity); }\end{array}$ & $\begin{array}{l}\text { activities. } \\
\text { ack orforming cognitive and other }\end{array}$ \\
\hline $\begin{array}{l}\text { 3. the ability to understand the } \\
\text { content of emotions, their } \\
\text { causes and effects (emotional } \\
\text { understanding) }\end{array}$ & $\begin{array}{l}\text { misunderstanding of the causes } \\
\text { and consequences of emotions, } \\
\text { inability to differentiate them }\end{array}$ \\
\hline $\begin{array}{l}\text { 4. the ability to regulate one's } \\
\text { own and others emotions (e.g. } \\
\text { to be able to calm others) } \\
\text { (emotional management) }\end{array}$ & $\begin{array}{l}\text { inability to regulate one's own } \\
\text { and others emotions }\end{array}$ \\
\hline
\end{tabular}

Due to results of this questionnaire, the author has created a five-factor model of emotional intelligence, which includes: intrapersonal qualities (ability to understand oneself and express one's feelings), interpersonal abilities (ability to accept, understand other 
people and interact with them), adaptability, stress management and general mood.

In the model of R. Bar-On, emotional intelligence is an intrapersonal trait, represented by emotional self-awareness, selfrespect, self-actualization, independence, self-confidence. Interpersonal traits are represented by empathy, interpersonal relationships and social responsibility. The third property - stress management - includes the ability to solve problems, a sense of reality, flexibility. Adaptability involves stress tolerance and impulsivity control. The general mood includes happiness and optimism of personality.

The intrapersonal sphere refers to a person's ability to understand and manage one's manifestations. It includes:

- introspection - the ability to recognize what a person is feeling and why, to understand how one's behavior affects other people

- assertiveness - the ability to express one's thoughts and feelings openly, and to defend one's own point of view.

- independence - the ability to direct and control yourself

- self-esteem - the ability to accept one's own strengths and weaknesses and feel good about yourself

- self-realization - the ability to realize one's full potential and be satisfied with one's own achievements.

The interpersonal sphere is about social skills and the ability to interact with others. To this area Bar-On includes:

- empathy - the ability to understand what other people may be feeling at the moment;

- social responsibility - the ability to collaborate with others and be a useful member of one's social group.

The adaptive sphere (adaptability) includes:

- realism - the ability to see reality as it is, filtering out one's own fears and projections;

- flexibility - the ability to relate one's own feelings, thoughts and actions to changing environmental conditions;

- problem-solving skills - the ability to identify a problem and establish an effective solution. 
Stress management - this sphere of emotional intelligence refers to the ability to withstand stress and control one's impulses. It includes:

- resistance to stress - person's ability to remain calm and constructive in adverse conditions;

- impulse control - the ability to delay the impulse of activity.

General mood includes:

- optimism - person's ability to maintain a realistic and positive attitude;

- life satisfaction - the ability to be satisfied with one's life and to make others feel joy.

The author considers an emotionally capable person as the one with high adaptive potential which includes stress tolerance and impulse control, stress management through the ability to solve problems, flexible approaches to finding the optimal solution based on the feeling of reality

In 1995, Daniel Goleman ${ }^{5}$ expanded and publicized the early model of emotional intelligence of J. Mayer and P. Salovey. To those components that were already highlighted (emotional identification, expression and regulation; use of emotional information) he added enthusiasm, persistence and social skills.

Published in 1995, D. Goleman's book "Emotional Intelligence" has not only become extremely popular in academia but also widespread among ordinary readers. It has actually initiated the development of the topic of emotional intelligence in management and business. D. Goleman subsequently finalized the structure of emotional intelligence, which then included four components - selfawareness, self-control, social sensitivity, relationship management and 18 related skills.

Emotional self-awareness implies the ability to understand one's emotions and their impact on one's psychological state and use of intuition when making decisions. Also, the concept of emotional self-

\footnotetext{
${ }^{5}$ Goleman D. Emotional intelligence. New York: Bantam Books, 1995.
} 
awareness involves accurate self-assessment, that is, acceptance of one's personal strengths and weaknesses and self-confidence.

Self-control includes the ability to restrain impulses, frankness (as honesty and directness) and adaptability, that is, flexibility in adapting to changes, the will to win, initiative, optimism and social skills.

According to D. Goleman, social sensitivity includes: compassion, i.e. the ability to understand the feelings of others, empathy, so-called "business awareness" (attention to current events), and positive attitudes toward others (courtesy).

Relationship management as a structural component of emotional intelligence implies inspiration, influence and contributing to changes, conflict management, teamwork and collaboration.

The dispositional model of emotional intelligence was proposed by English researchers K.V. Petrides and A. Furnham ${ }^{6}$. This model connects certain personality traits with the development level of person's emotional intelligence and emotional functioning as a whole. When describing emotional intelligence K.V. Petrides and A. Furnham use not only the set of abilities proposed by Mayer and Salovey, but also suggest that its dispositional components should be taken into account. The authors of this model of emotional intelligence talk about its dependence on the style of behavior, experience and context of the situation, and admit that the emotional experience of the individual is subjective.

Aspects of identifying dispositional EI for an adult

\begin{tabular}{|l|l|}
\hline \multicolumn{1}{|c|}{ Aspects of identifying } & \multicolumn{1}{|c|}{$\begin{array}{c}\text { High levels of EI identifying } \\
\text { indicate that a person }\end{array}$} \\
\hline \multicolumn{1}{|c|}{$\mathbf{1}$} & \multicolumn{1}{c|}{$\mathbf{2}$} \\
\hline Adaptability & $\begin{array}{l}\text { perceives itself as flexible, ready to } \\
\text { adapt to new living conditions }\end{array}$ \\
\hline Assertiveness & $\begin{array}{l}\text { is straightforward, frank, has the } \\
\text { will to protect others' rights }\end{array}$ \\
\hline
\end{tabular}

${ }^{6}$ Petrides K.V., Furnham A. On the dimensional structure of emotional intelligence // Personality and Individual Differences. 2000. V. 29. 
End of table

\begin{tabular}{|c|c|}
\hline 1 & 2 \\
\hline $\begin{array}{l}\text { Awareness of your own } \\
\text { emotions and other people's } \\
\text { emotions }\end{array}$ & $\begin{array}{l}\text { is able to clearly perceive one's } \\
\text { own and other people's emotions } \\
\text { and feelings }\end{array}$ \\
\hline xpression & $\begin{array}{l}\text { capable to adequately convey one's } \\
\text { feelings in communication with } \\
\text { other people }\end{array}$ \\
\hline $\begin{array}{l}\text { Regulating other people's } \\
\text { emotions }\end{array}$ & $\begin{array}{l}\text { can influence other people's } \\
\text { feelings }\end{array}$ \\
\hline Emotional self-regulation & $\begin{array}{l}\text { is able to control one's own } \\
\text { emotions }\end{array}$ \\
\hline (low) & not succumb to impulses \\
\hline $\begin{array}{l}\text { Relationships with other } \\
\text { people }\end{array}$ & $\begin{array}{l}\text { is able to maintain friendly and } \\
\text { healthy personal relationships with } \\
\text { others }\end{array}$ \\
\hline $\mathrm{S}$ & feels successful and co \\
\hline Self & $\begin{array}{l}\text { is motivated to achievement and } \\
\text { demonstrates low probability of } \\
\text { losing confidence in the face of } \\
\text { adversity }\end{array}$ \\
\hline Soci & has high social skills \\
\hline Stress management & $\begin{array}{l}\text { is able to withstand pressure and } \\
\text { regulate stress }\end{array}$ \\
\hline Empathy as a trait & $\begin{array}{l}\text { is ready to sympathize with the } \\
\text { other person }\end{array}$ \\
\hline $\begin{array}{l}\text { Happiness as a personality } \\
\text { trait }\end{array}$ & $\begin{array}{l}\text { feels joy and satisfaction with } \\
\text { one's own life }\end{array}$ \\
\hline Optimisr & $\begin{array}{l}\text { is confident and ready to see first } \\
\text { and foremost "the bright side of } \\
\text { life". }\end{array}$ \\
\hline
\end{tabular}

The most famous concept of emotional intelligence in the countries of the former Soviet Union is the one proposed by 
D. Liusin ${ }^{7}$. Building on previous theories, he defines emotional intelligence as the ability to understand and manage one's and others' emotions. D. Liusin also considers incorrect the interpretation of emotional intelligence as a purely cognitive function.

D. Liusin writes that "emotional intelligence can be represented in the form of dual nature: cognitive abilities and personal characteristics". Considering the concept of emotional intelligence, D. Liusin notes that "psychological education is forming throughout person's life and is influenced by factors that determine its level and individual characteristics".

D. Liusin explains that he interprets the concept of the ability to understand and manage emotions as follows:

- a person is able to recognize emotion, that is, to establish the existence of certain experience inside oneself or another person;

- a person is able to identify an emotion, that is, to determine what emotion he or another person experiences and to find a verbal equivalent;

- an ability to understand the reasons that caused a particular emotion and its consequences;

A person's ability to manage emotions implies that a person is able to:

- control the intensity of emotions, especially to muffle strong emotions;

- control the external display of emotions;

- evoke one or another emotion if necessary.

D. Liusin believes that the ability to understand and manage emotions can be directed both to one's own emotions and to the experiences of other people. Thus, D. Liusin supports the view of most researchers that emotional intelligence includes both the intrapersonal and the interpersonal spheres. This orientation of emotional

${ }^{7}$ Liusin D.V. Ability to understand emotions: Psychometric and cognitive aspects // GA. Emelianov (Ed.), Social learning in the era rapid political and economic change. M .: Sense, 2000. 
intelligence is supposed to implement different cognitive processes and skills, however directly related.

The author suggests that the ability to understand and manage the emotional sphere is closely related to the general personality traits, and requires in the first instance an interest in the inner world (including one's own), tendency to analyze behavior and to attach great importance to emotions. D. Liusin proposes to envisage emotional intelligence as a construct with a two-component nature on the one hand, it is connected with the cognitive sphere, on the other, with the personal properties of man.

Emotional intelligence is forming throughout person's life and is influenced by various factors, which shape its specificity and individual peculiarities. D. Liusin identifies three groups of such factors: cognitive abilities, ideas about emotions, peculiarities of emotionality.

D. Liusin emphasizes that intellectual tests and questionnaires can be used to measure the construct of emotional intelligence. Questionnaires that focus on reflection, rather than correctness of answer, are more suitable for measuring of intrapersonal emotional intelligence. When measuring interpersonal emotional intelligence it is more appropriate to use tasks (cases), but this raises some particular difficulties in determining the correct answer.

Thus, the most well-known and grounded theories of emotional intelligence were considered: the non-cognitive theory of R. Bar-On, the theory of emotional and intellectual abilities of J. Mayer and P. Salovey, the theory of emotional competence of D. Goleman, the dispositional approach of K.V. Petrides and A. Furnham and the twocomponent theory of D. Liusin. The common understanding in all these theories is that they define emotional intelligence as a set of abilities to understand and manage both one's own emotions and those of others.

At the present stage, most researchers of emotional intelligence define it as a set of emotional-cognitive abilities for social and psychological adaptation of the individual. People with high levels of emotional intelligence have an expressed ability to understand their 
own and others' emotions, are able to manage their emotional sphere and, as a result, are more adaptable, more effective in communicating and interacting with others.

\section{Methodology of the emotional intelligence research}

The research of emotional intelligence in a IT-sphere at post soviet sphere is not very popular. Basic researches of emotional intelligence in Russia are conducted by D. Liusin in a collaboration with the American researchers R.Roberts, Dzh.Metiuz and develops the ideas of emotional intelligence and its practical significance in the different spheres of human activity. Authors observed different methodologies of the emotional intelligence diagnostics that are based on various approaches to determination of this concept, compared their structure and fillingness. They grouped all methodologies for diagnostics of emotional intelligence in two sub-groups: 1) methodologies-questionnaires that concern an emotional intelligence as difficult formation with cognitive nature and as personal description; 2) methodologies-tests that consider the emotional intelligence as cognitive description. In the further works D. Liusin develops own methodology of emotional intelligence diagnostics based on the theory of structure and development possibilities.

F. Bruks, H. Veinberh, N. Virt, E. Deikstra, S. Makkonnell, M. L. Smulson, B. Shneiderman, R. Hebriel, V. Volkonska, Yu. Babaieva, A. Voiskunskyi and others investigated the personal characteristics of programists and workers in the IT sphere ${ }^{8}$. It is now possible to meet the particular publications, dedicated to the range of problems of the professional or emotional exhaustion, research of stress resistance and coping strategies, leader qualities and

8 Kuzmyna K. E. Personal features of professional users of computer technologies. Psychological and pedagogical support in the educational institutions of the Russian Federation of the formation of a person as a person at the stage of intergenerational transition of youth: Sat. articles / Under the general editorship of S.P. Ivanova. M Publishing house of Moscow Psychological and Social 2008. From the Institute, 180-185. 
communicative skills for the IT-sphere workers. M. Nekrestianova and S. Miasnykova ${ }^{9}$ are ones of the few who researches the emotional intelligenge in the emotional technology sphere, in particular its influence on leader success in IT sphere I. Rohozhkina proved the developing effect of programming studies, that contradicts the generally accepted idea about sphere narrowing of interests and certain predominance of cognitive processes.

O. Shnaider research the programmer psychology in Ukraine ${ }^{10}$. He investigated the emotional exhaustion of programmers in the light of alexithymia and emotional intelligence. However, in his researches the indexes of emotional intelligence act as auxiliary.

Within of this article the methodology of emotional intelligence in the workers at IT industry research will be studied. In particular, there is the tooling that will extend possibilities for research and development of emotional intelligence.

For the first time the term an emotional intelligence was used by P. Salouei and Dzh. Maiier. They understand this term as one of types of capabilities, in particular social. Accordingly this cognitive construct as one of the intellect types, scientists suggest to measure with the help of objective tests. Now there are two methodologies of these authors: MEIS and MSCEIT, the second methodology is the extended option of the first one. These methodologies are based on the 4-factorial model. Within the framework of this model an emotional intelligence is determined as a set of capabilities that have a hierarchical structure. These capabilities are incorporated in 4 "branches": 1) perception of emotions, 2) increases of thinking efficiency with the help of emotions, 3) understanding of emotions, 4) emotion management. Within these tests the investigated have to

\footnotetext{
${ }^{9}$ Nekrestyanova MS, Myasnikova SV Emotional intelligence as a factor in the success of a leader in the field of information technology Scientific research of graduates of the psychology department of SPbGU Publishing house: St. Petersburg State University. - TI-El 2013. - C. 172-179

${ }^{10}$ Schneider O. V. Psychologistichny especialists of the emerald warhorse Scientific notes in the sphere of informational technologies for the National Ostrozka Academy. Seria "Psychologists and Teachers". Vypot. 26. 2014. P. 144-148
} 
perform a task. These tasks are estimated with objective assessement. There are 2 types of assessement: expert and average estimations that were determines as certain part of investigated during methodology standardization. These methodologies have high validity and reliability. Russion translation and adaptation was carried out during 2008-2010 by the command of Institute of psychology of Russian Academy of Sciences researchers under the direction of E. Serhiienka and I. Vitrovoi. Adaptation was conducted by double translation from English to Russian and vice versa. Translation was not accomplished word for word, but with the use of terminology, usual for Russian native speakers, however alike after sounding. Images were unchanged in the text. It can cause difficulties in perception and interpretation of emotions in the stages which are typical for American society. Authors assure that modern television and internet give a wide idea about life in American society and that it can serve as good basis for the use of test.

Questionnaire R.Bar-On EQ is based on the model ofemotional intellect, that was worked out by R.Bar-On. He suggests to examine an emotional intelligence as construct, that unites all discognitive capabilities of people, that give an opportunity to cope with life situations. In the structure of its construct 5 subcomponents are marked: 1) cognition itself: realization of the emotions, confidence, self-esteem, self actualization; 2) interpersonal skills: empathy, interpersonal relations, social responsibility; 3) capacities for adaptation: problem solution, connection with reality, flexibility; 4) management of stress situations: resistance to stress, control over impulsiveness; 5) prevailing mood:happiness, optimism. Any empiric data that would be basis for this methodology are absent. It bases only on the theoretical analysis of literature and author hypothesis.

One of the most popular methodologies at post-soviet time is the methodology of M. Kholl. The authord istinguishes 5 scales: 1) emotional awareness, 2) emotional management 3) self-motivation, 4) empathy, 5) emotion recognition of other people. However in the literature there is no information about empiric data and psychometrics of this methodology. 
D. Liusin, based on the analysis of theories of emotional intelligence and methods for his study, developed his own theory. In his understanding of emotional intelligence is the ability to understand their and others' emotions and their management. The author is invited to consider these abilities in two dimensions: in an interpersonal and intrapersonal interaction. Methodology Approbation has taken place but standardization continues, accordingly, the data of reliability and validity of the methodology, which are now considered to be preliminary.

Analyzing the above-described Techniques It is possible to recommend the technique of studying emotional intelligence among the IT-sphere workers in Ukraine, in particular, in Lviv, D. Liusin's method. Such a choice is due to the relative simplicity of the technique, the clarity of the instruction and the lack of the need for translation. These criteria are important because, in the given conditions of study, firstly there are no instructors, ie the researcher will remain alone with the computer and the task: secondly, the Russian-language text in the original is available for understanding and analysis as both Ukrainian and Russian-speakers and does not require double translation. In addition, the mass methodology confirms the psychometric performance at an adequate level.

For a broad analysis of emotional intelligence, it is also important to analyze the related characteristics and personality characteristics that can be the basis for its formation. Usually researchers include alexithymia and emotional burnout in their programs. These indicators are important for understanding the formation and development of emotional intelligence, but often inadequate. To analyze the emotional intelligence of lawyers in the IT sphere it is also appropriate to study the features of social adaptation and anxiety.

Such a methodological complex will take into account the peculiarities of professional activity of IT specialists, in particular, programmers. The specificity of this activity is that the interaction of programmers in the professional core business with the technique. 
Some researchers note that programmers who write code have a specific structure for perception and analysis of information.

In particular, they have a high level of abstract thinking. Often their abstractions are complex, multilayered and multidimensional. They are inclined to categorize and perceive reality with a metaphor. The emotional sphere can be developed in different ways, but one important feature that makes them the difference between experiencing emotions and their expression. It makes confusion in the analysis, because the study of the emotional sphere by studying the expression of emotions can lead to false conclusions about the affinity of the emotional sphere. While the study of experiences can show quite different results, another group of researchers ${ }^{11}$ thus describes the psychological portrait of an "ideal" programmer:

- persistence/passivity: persistent man possesses the necessary initiative to work;

- introversion/extraordinary: in collective co-operation and in cooperation with the user, a friendly alien style of relationships;

- internal/external controllability: individuals are expressing internal control by their own subjectivity;

- high/low excitability, moderate levels of excitability contribute to increased productivity;

- high/low motivation: individuals with a high level of motivation can perform very difficult tasks;

- high/low tolerance for uncertainty: developers should be able to work in conditions where a small number of facts or components are clearly identified;

- it is necessary to make decisions of limited input data for making another decision need to have a tendency to some risk;

- the ability to be precise: in the final stages of solving the task requires special attention to the details and readiness to check it to consider each detail;

${ }^{11}$ Schneiderman B. lleiholo prohrammirovashi: human factors in iislitelnyh and information systems. Trans. with English. M. Panto it connection. 1984. - 304 p. 
- modesty: a good program should be too self-confident about the quality of their programs;

- the ability to overcome stress: in cases of lagging behind planned terms, the ability to work well in a stressful situation is required.

In the above list one can notice that emotionality is not singled out separately. However, the points of "high/low excitability", "high low motivation", "the ability to overcome stress" suggest the emotional basis of these components, both in terms of" activation "motivational and the approaches to I. Illin.

Another parallel between the features of the emotional sphere and the professional activity of programmers is traced in the studies of emotional burnout.

O. Schneider, as a result of the study of emotional burnout in programmers, found that the ability to manage their behavior through emotional management is associated with emotional burnout. The author assumes that in a situation when in the process of human activity, person is not able to find an optimal and adequate way of expressing their emotions, "suffering" activities, emotions are not so much an energy resource, as they inhibit motivation.

\section{CONCLUSIONS}

The development and substantiation of the methodology for the study of emotional intelligence of IT staffers is a significant stage in the research work. At the moment, a whole range of techniques for the study of emotional and that are different both the theoretical basis and understanding of the basic and the concept of the structure of tools. Taking into account the various features of the techniques for the study of emotional intelligence in Ukraine, it is suggested to use the technique of D. Liusin. For a broad understanding of the processes of development of emotional intelligence, adding to the research parameters of personal anxiety, situational anxiety, adaptation. the removal of others. For the wide understanding of processes of development, emotional intellect, adding to research of parameters, personality anxiety, situation anxiety, adaptation, acceptance other, 
self-perception, emotional comfort, aspiring to prevailing it can be enough informing. Thus, the prospects for the implementation of the results of research in practical activities in the professional and in the personal sphere are opened.

\section{SUMMARY}

Work is devoted to methodology of selection and description, their combination for research emotional intelligence at workers of IT sphere. It was analysed the necessity of wide study of processes of emotional sphere in the context of researching emotional intellidence. In particular, alexithymie, anxiety, emotional exhaustion and their possible intercommunications with forming and development of emotional intellect.

\section{REFERENCES}

1. Andreeva I.N. (2004) The concept and structure of emotional intelligence. Socio-psychological problems of mentality: International scientific-practical conference. Smolensk SSPU 2004. vol. 4 pp. 22-26.

2. Bar-On R. (1997) The Bar "On Emotional Quotient Inventory (EQ" i): Technical Manual. Toronto: Multi "Health Systems.

3. Buck R. (1991) Motivation, emotion and cognition: A developmental-interactionist view // Strongman K.N. (ed.). International review of studies on emotion V.T. Chichester: Wiley.

4. Gardner H. (1993) Multiple intelligences. N.Y.

5. Goleman D. (1995) Emotional intelligence. New York: Bantam Books.

6. Kuzmyna K. E. (2008) Personal features of professional users of computer technologies. Psychological and pedagogical support in the educational institutions of the Russian Federation of the formation of a person as a person at the stage of intergenerational transition of youth: Sat. articles / Under the general editorship of S.P. Ivanova. M Publishing house of Moscow Psychological and Social, pp. 180-185. 
7. Liusin D.V. (2000) Ability to understand emotions: Psychometric and cognitive aspects. GA. Emelianov (Ed.), Social learning in the era rapid political and economic change.

8. Mayer J.D. (2005) Emotional intelligence: Popular or scientific psychology. [Electronic resource.] Retrieved from: http://www.apa.org/monitor/sep99/

9. Mayer J.D., Salovey P., Caruso D.R., Sitarenios G. (2001) Emotional intelligence as a standard intelligence. Emotion. V. 1.

10. Nekrestyanova M.S., Myasnikova S.V. (2013) Emotional intelligence as a factor in the success of a leader in the field of information technology Scientific research of graduates of the psychology department of SPbGU Publishing house: St. Petersburg State University. pp. 172-179.

11. Petrides K.V., Furnham A. (2000) On the dimensional structure of emotional intelligence // Personality and Individual Differences. v. 29.

12. Roberts RD, Momyos D., Zaydncr M., Lyusin D.V. (2004) Emotional intelligence: problems of theory, measurement and application in practice Psychology. Journal of the Higher School of Economics. vol. 1. no 4. pp. 3-26.

13. Salovey P., Mayer J.D. Some final thoughts on personality and intelligence // Sternberg J., Ruzlis P. (Eds). (1994) Personality and intelligence. Cambridge: Cambr. Univ. Press.

14. Stasyuk M. (2017) Specialties of the Dimensional Sphere IT-cialis. Science and Education a New Dimension. Pedagogy and Psychology vol. (59) pp. 82-86 Retrieved from: http://seanewdim.com/ uploads/3/4/5/1/34511564/ped_psy_v59_134.pdf

15. Schneider O. V. (2014) Psychologistichny especialists of the emerald warhorse Scientific notes in the sphere of informational technologies for the National Ostrozka Academy. Seria "Psychologists and Teachers". vol. 26. 2014. pp. 144-148.

16. Schneiderman B. (1984) lleiholo prohrammirovashi: human factors in iislitelnyh and information systems. Trans. with English. M. Panto it connection. pp. 304. 
17. Thorndike R. (1986) Stanford-Binet Intelligence Scale: $4^{\text {th }}$ edition (Technical Manual) / Thorndike, R., Hagen, E., and Sater.

\section{Information about the author:} Mariia Stasiuk, Postgraduate Student at the Department of Psychology, Ivan Franko National University of Lviv 1, Universytets'ka str., Lviv, 79000, Ukraine ORCID ID: https://orcid.org/0000-0003-3926-6618 
DOI https://doi.org/10.36059/978-966-397-161-2/117-140

\section{THE GENESIS OF THE RESEARCH OF DETERMINANTS OF PROFESSIONAL STABILITY OF A FUTURE PSYCHOLOGIST'S PERSONALITY: CONCEPTUALIZATION AND EMPIRICAL REFERENTS}

\section{Hanna Varina}

\section{INTRODUCTION}

In order to implement Ukraine's strategic course for integration into the European Union, to ensure Ukraine's full integration into European political, economic and legal space and to create preconditions for Ukraine's membership in the European Union. The Decree of the President of Ukraine approved the Strategy of Ukraine's integration into the European Union. The main areas of cultural, educational, scientific and technical integration are the implementation of European norms and standards in education, science and technology and the dissemination of their own cultural, scientific and technological achievements in the EU.

Entering into this space for Ukraine means an orientation towards state and public principles of government; raising the role of alternative systems and innovation processes; widespread introduction into all spheres of new (first of all information) technologies; environmental, cultural and logical orientation of education and science; providing citizens with the right of choice, equal conditions for general education, access to science, regardless of their social and genetic capabilities; moral and spiritual improvement of citizens; ensuring the continuity of personal education throughout life. This process has particular importance in the reformation of a new model of the future specialist, able in the changing and unstable social and economic, political and cultural conditions of the modern society to self-transformation, self-realization and preservation of professional stability, competitiveness in job market demands and transformations. Modern higher education is a catalyst for the subject's independent 
transition from a strategy of self-reflection to a strategy of selftransformation, the reconstruction of subjective experience, which responds to its tasks within the new humanistic paradigm and enables to use internal resources constructively in professional activity. The raise of the social demand for the services of applied psychologist, able to solve the tasks competently, to respond to changes in society quickly, while maintaining professional stability and competitiveness.

Optimization of the process of formation of professional stability as a component of the positive self-concept of personality in the conditions of modern cultural and educational space by future applied psychologists is possible through the implementation of a holistic systematic and structural program of their targeted training that will be as close to the activity as possible ${ }^{1}$. Thus the degree of realization of professional stability of the future applied psychologist depends to a great extent on the development of his dialogical, spiritual and reflexive spheres, which provides the professional level and personal and professional potential. Awareness of the future applied psychologist of the relation of the professional requirements with its personal traits leads to the construction of one's own personality within the framework of professionalization and creates the conditions for constructing oneself as a professional resistant to changing social demands. The raise of the requirements for professionalism and personal component of the applied practical psychologist, orientation to competitiveness and competence require reformation of both the model of the future specialist and the training system as a whole ${ }^{2}$. The complexity of mastering the profession of applied psychologist is that, in addition to acquiring knowledge,

1 Panok V.Gh., Umanecj L.I. (1999) Osobystistj praktykujuchogho psykhologha. Psykhoterapevtychna sytuacija. Osnovy praktychnoji psykhologhiji: Pidruchnyk [Personality of the practicing psychologist. Psychotherapy situation. Fundamentals of Practical Psychology: A Textbook]. Kiev: Libid (in Ukrainian)

Krupnik E.P. (1995) Problema psikhologicheskoy ustoychivosti. Psikhologicheskie aspekty sotsial'noy nestabil'nosti [The problem of psychological stability. Psychological aspects of social instability]. Moscow: Moscow State Pedagogical University (in Russian) 
practical skills and abilities, you need to do a great job of forming a willingness to withstand the negative factors and the ability to maintain a high level of performance despite various stressful factors during the study. In other words, a sufficient level of professional training of the future psychologist is possible only if a certain level of development of components of professional stability is maintained, such as determinants of the professional and personal potential of the specialist. It is the search of ways and methods of formation of professional stability of the future applied psychologist in the modern cultural and educational environment that raises urgent questions in the sphere of reformation of the training system of competitive specialist.

\section{The conceptual model of development of professional stability of the future psychologist in the conditions of cultural and educational space}

Under psychological stability we mean such a personality trait, which shows the intensity and effectiveness of professional orientation. According to E.M. Kovalchuk, professional stability means the correspondence of the motives and interests of the individual to the real content of his work. If such conformity is observed, the person successfully copes with professional activity, is less tired and annoyed. On the basis of this we can talk about the mental or psychological activity of the individual, which determines its stability ${ }^{3}$. Analyzing the concept of personal stability from a psychological point of view, V.E. Chudnovsky consider it as two levels: a) defensive, in which a person retains his personal qualities, resists external actions that interfere with his personal positions and attitudes; b) offensive, which is related to the ability of a person to

\footnotetext{
3 Varina H. (2018) Psikhologicheskie aspekty ekspertizy emotsional'novolevoy sostavlyayushchey professional'noy ustoychivosti budushchego prakticheskogo psikhologa [Psychological aspects of the examination of emotionalvolitional component of professional sustainability of the future practical psychologist] Fundamental and applied researches in practice of leading scientific schools, no. 27(3), pp. 106-110
} 
realize his personal positions, to transform circumstances and his own behavior ${ }^{4}$. N. Podimov interprets psychological stability as a moving equilibrium and an optimal ratio of dialectically contradictory psychological structures of personality, which gives rise to such mental tumors that determine the "resistance" of the psyche in relation to both external and internal actions. Such stability ensures the preservation of the psyche in a constantly changing environment, the orientation of actions and actions, regardless of the negative influence of external factors. It should be noted that the stability of the psyche can rotate its rigidity. It "has a controversial psychological nature, can act as a stabilizing factor and as a factor blocking the dynamics of mental structures of the individual"5. The concept of modernization of education has set the task of forming the creative and highly competent personality of applied psychologist as a subject of psychological activity. Due to this, the psychologist finds freedom in making independent decisions, reliability and professional stability.

In determining the essential characteristics of the professional stability of the psychologist, we proceeded from the following methodological ideas:

- stability is a qualitative characteristic of an object, system or individual; the quality is understood as some certainty of the subject or individual who has certain specific properties;

- stability manifests itself in holistic systems whose selforganization is impossible without the existence of a hierarchical structure of internal factors;

- stability of the personality of the psychologist is formed in the process of self-determination and becoming a specialist and is manifested in his activity and active self-organization;

4 Chudnovskiy V.E. (1984) Nravstvennaya ustoychivost' lichnosti: psikhologicheskoe issledovanie [Moral stability of personality: a psychological study]. Moscow: Pedagogy (in Russian)

5 Krupnik E. P., Podymov N. A. (1999) Psikhologicheskaya ustoychivost' uchitelya kak uslovie preodoleniya innovatsionnykh bar'erov $\mathrm{v}$ ego professional'noy deyatel'nosti [Psychological stability of a teacher as a condition for overcoming innovative barriers in his professional activity]. World of psychology . no.2, pp. 175-178 
- stability is the result of the functioning of mechanisms that actively counteract negatively influencing factors ${ }^{6}$.

Thus, the professional stability of the future psychologist is an integrative qualitative characteristic of him as a subject of psychological activity, which reflects the high level of stabilization of value attitudes, emotional and volitional processes and states.In order to determine the degree of influence of various negative factors on the development of professional stability of the future psychologist, we offered the students of the specialty 053 Psychology of Melitopol State Pedagogical University named after Bogdan Khmelnytsky the questionary, in which they had to choose from the proposed list difficulties, which are complicated for them in the process of becoming a specialist. Seventeen proposed factors were broken down into four groups: factors related to the personality traits of the subject of psychological activity, factors related to the level of theoretical training in the specific disciplines, social and psychological factors and factors related to professional competence.

Table 1

\section{The influence of negative factors on formation of professional stability of future applied psychologist [made by author]}

$\mathrm{N}=140$

\begin{tabular}{|l|c|}
\hline \multicolumn{1}{|c|}{ Groups of Negative Factors } & $\begin{array}{c}\text { Percentage of } \\
\text { Manifestation }\end{array}$ \\
\hline $\begin{array}{l}\text { 1. Factors related to the personal traits of the } \\
\text { subject of psychological activity }\end{array}$ & $39 \%$ \\
\hline $\begin{array}{l}\text { 2. Factors related to the level of theoretical } \\
\text { training in the specific disciplines }\end{array}$ & $26 \%$ \\
\hline 3. Social and psychological factors & $67 \%$ \\
\hline 4. Factors related to professional competence & $51 \%$ \\
\hline
\end{tabular}

6 Krupnik E.P. (1995) Problema psikhologicheskoy ustoychivosti. Psikhologicheskie aspekty sotsial'noy nestabil'nosti [The problem of psychological stability. Psychological aspects of social instability]. Moscow: Moscow State Pedagogical University (in Russian) 
The largest number of respondents believe that the main difficulties in psychological activity are caused by social conditions of life $(67 \%)$. The following are the factors related to the level of professional competence $(51 \%)$, then - the personal traits of the student $(39 \%)$ and the last place in a number of reasons causing difficulties in psychological activity are the factors related to the lack of theoretical knowledge in special disciplines. (26\%). The analysis of the obtained results revealed the following:

1. In a number of personal traits of a psychologist, $34 \%$ of respondents noted the lack of focus on activity; $17 \%$ highlighted the reluctance to communicate with children; $6 \%$ - psychological tension due to self-doubt; $5 \%$ - inability to regulate their emotional state.

2. Among the difficulties associated with the lack of theoretical training in the specialized disciplines, the first place was taken by the lack of knowledge in the basic subject (22\%). This is followed by the absence of a systematic view of the subject as a science (12\%), the inability to practically solve psychological and pedagogical situations $(7 \%)$.

3. According to the interviewees, the greatest difficulties in terms of social and psychological conditions are the lack of equipment (38\%). Heavy financial standing is noted by $32 \%$ and congestion by $42 \%$ of respondents.

4. In the last group of factors there are not enough development of psychological skills and low level of development of communicative and organizational abilities (22\% each); inability to use the theoretical gained experience (18\%).

Professional resilience is double. On the one hand, it is the ability of a person to maintain his or her personal positions and to resist influences that are contrary to his or her personal preferences. On the other hand, it is the ability to realize one's personal positions by changing circumstances and regulating one's behavior. Professional stability of the individual can be considered as a complex quality of personality, the synthesis of individual qualities and abilities. Professional stability is supported by internal (personal) resources and external (interpersonal, social support, working conditions). 


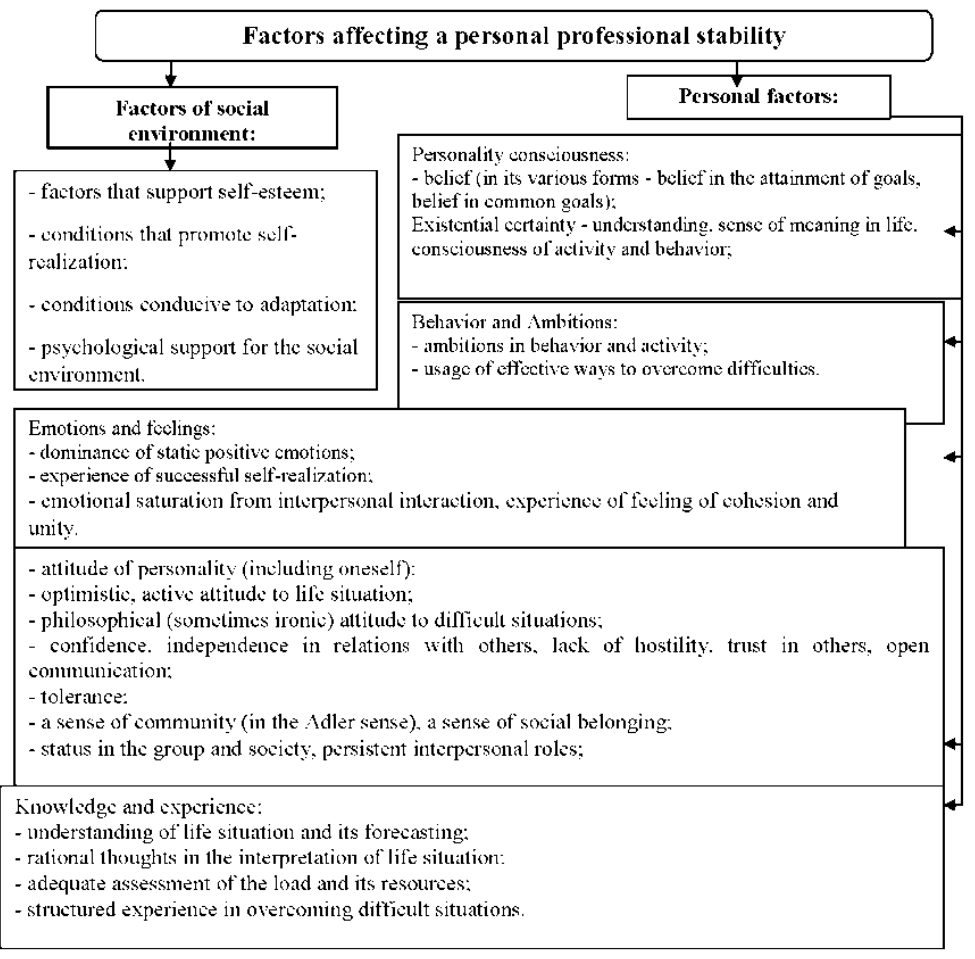

\section{Fig. 1. The characteristics of the main factors affecting the professional stability of the individual [made by author]}

We highlighted the main determinants of the development of professional stability of the individual. With the presence of these factors a favorable mental state and high mood, which are suitable for successful behavior, activity and personal development, remains. In foreign psychology, less attention is paid to personal factors of stability, with a closer look at only a few of the main factors related to the functioning of the individual in the social environment. Thus, B. Bernard identifies four major personal stabilityfactors ${ }^{7}$ :

${ }^{7}$ Bernard B. (1991) Sodeystvie ustoychivosti u detey: zashchitnye faktory $v$ sem'e, shkole i obshchestve [Fostering Resiliency in Kids: Protective Factors in the Family, School and Community]. Minneapolis : University of Minnesota (in English) 
1. Social competence (which includes sensitivity, sociability, empathy, caring, compassion, altruism and the ability to forgive).

2. The ability to solve problems (ability to plan, flexibility, resourcefulness, critical thinking, insightful thinking).

3. Autonomy (which includes positive identity, internal locus of control, initiative, self-efficacy, mastery, adaptive distance from others, resilience, self-awareness and sense of humor).

4. Awareness of the purpose and the future (which includes the purpose-direction, success orientation, motivation for achievement, educational orientation, persistence, optimism, belief in a bright future, a sense of consistency, spirituality, meaning of life, creativity, developed imagination).

In the context of our study of the structure of professional personal stability, it is interesting to consider the research of the Center for Stability Studies at the University of Minnesota, which has developed a special structure for the identification of personality stability: faith $\rightarrow$ the ability to overcome adverse conditions $\rightarrow$ life strategies $\rightarrow$ individual achievements $\rightarrow$ social achievements ${ }^{8}$. This scheme allows to plan and implement effective preventive programs in the process of development of sanogenic potential and professional stability of the future specialist. As a result of theoretical analysis, we were able to identify the following components in the structure of professional stability of the future practical psychologist: motivational, cognitive, connotative, reflexive and valuable, regulatory and volitional.

Let us consider the substantive characteristics of each of the components of professional stability of the future psychologist.

8 Varina H.B. (2018) Profesijna stijkistj jak integhratyvnyj komponent sanoghennogho potencialu osobystosti [Professional resilience as an integrative component of the sanogenic potential of the individual]. Suchasni zdorov'jazberezhuvaljni tekhnologhiji: kolektyvna monoghrafija [Modern Healthcare Technologies: A Collective Monograph]. Kharkiv: Hryhoriy Skovoroda Kharkiv National Pedagogical University, pp. 67-73 
THF COMPONENTS TO PROMOTE. PROFFSSIONAI. STABII.ITY OF A FUTURE APPIIIED PSYCIIOIOGIST

\begin{tabular}{|c|c|c|c|c|}
\hline $\begin{array}{l}\text { Motivational } \\
\text { component }\end{array}$ & $\begin{array}{l}\text { Cognitive } \\
\text { component }\end{array}$ & \begin{tabular}{|l|} 
Connotative \\
component
\end{tabular} & $\begin{array}{ll}\text { Reflexive } & \text { and } \\
\text { valuable } & \\
\text { component } & \\
\end{array}$ & $\begin{array}{l}\text { Regulatory } \\
\text { and volitional } \\
\text { component }\end{array}$ \\
\hline \multirow[t]{2}{*}{$\begin{array}{l}\text { Molives related } \\
\text { to } \quad \text { luture } \\
\text { professional } \\
\text { activity }\end{array}$} & $\begin{array}{l}\text { Knowledge } \\
\text { about patterns of } \\
\text { future } \\
\text { professional } \\
\text { activity in the } \\
\text { ficld of applied } \\
\text { psychology }\end{array}$ & \multirow[t]{2}{*}{$\begin{array}{l}\text { l'he possession of } \\
\text { the means of } \\
\text { organization and } \\
\text { creative solution } \\
\text { of tasks of future } \\
\text { professional } \\
\text { activity }\end{array}$} & The ability to refled & $\begin{array}{l}\text { The volitional } \\
\text { regulation of } \\
\text { future activity }\end{array}$ \\
\hline & $\begin{array}{l}\text { Knowledge } \\
\text { about principles. } \\
\text { dircetions and } \\
\text { technologies of } \\
\text { psychological } \\
\text { activity }\end{array}$ & & $\begin{array}{l}\text { The valuable } \\
\text { orientations in } \\
\text { future professional } \\
\text { activity }\end{array}$ & $\begin{array}{l}\text { The ability to } \\
\text { self-regulation }\end{array}$ \\
\hline $\begin{array}{l}\text { Motives related } \\
\text { to the } \\
\text { development of } \\
\text { professionally } \\
\text { signilicant } \\
\text { personality traits }\end{array}$ & $\begin{array}{l}\text { Spcific subject } \\
\text { knowledge }\end{array}$ & $\begin{array}{l}\text { Skills of } \\
\text { professionally } \\
\text { stable behavior }\end{array}$ & \multirow{2}{*}{$\begin{array}{lr}\text { Willingness } \\
\text { productive } \\
\text { communication } \\
\text { establishing and } \\
\text { trusting relationship } \\
\text { (level } \\
\text { communication } \\
\text { empathy } \\
\text { development) }\end{array}$} & $\begin{array}{l}\text { Volitional } \\
\text { regulation at } \\
\text { the stage of } \\
\text { self- } \\
\text { development }\end{array}$ \\
\hline $\begin{array}{l}\text { Motives for } \\
\text { achievements }\end{array}$ & $\begin{array}{l}\text { Knowledge } \\
\text { aboul yourself }\end{array}$ & $\begin{array}{|lr|}\text { Ability } & \text { to } \\
\text { reconstruct } & \\
\text { behavior } & \text { and } \\
\text { activity } & \text { in } \\
\text { changing } & \\
\text { environment } & \\
\text { (adaptive } & \\
\text { personality) } & \\
\end{array}$ & & $\begin{array}{l}\text { The level of } \\
\text { development } \\
\text { of emotional } \\
\text { regulation }\end{array}$ \\
\hline
\end{tabular}

\section{Fig. 2. Structural Components of Professional Stability of the Future Applied Psychologist [made by author]}

Motivational component. The success of any activity depends on the level of motivation. Motives generated by the need for psychological activity encourage the individual to set a specific goal, the achievement of which itself becomes a motive for the performance and continuation of this activity, to set its further goals. The motivation of a person is conditioned by his or her orientation, which includes values, interests, inclinations, goals, meanings, beliefs, ideals in which the outlook of the person is expressed. Orientation of personality determines the system of basic relations to the world and to 
himself, the semantic unity of his behavior and activity, creates stability of the individual, a willingness to withstand undesirable influences from the outside and inside, is the basis of professional selfdetermination, self-development and professionalism, the point of evaluation professional behavior.

Cognitive component. The cognitive component of a professional stability of a specialist is also based on his knowledge of himself. German psychologist N. Enkelman notes: "A person does not stand still, so it is necessary to find out about all changes in himself in time." Assessment of the strengths, abilities and capabilities is associated with the development of self-awareness of the individual and causes the desire for achievement and the development of the motivational sphere. Stability and adequacy of self-esteem are the basis for forming such personality traits as self-confidence, selfesteem, etc. ${ }^{9}$

Thus, the body of knowledge about the laws of future professional activity, knowledge about the principles, directions and technologies of activity, subject-specific knowledge, knowledge about the conformity of the personal traits of the future specialist to the requirements of the profession provide the psychologist with a broad orientation in the social and professional space, gives confidence in his powers. This knowledge creates a basis for the specialist to build the author's system of activity, allows to develop the desire for reflection, the image of "I", to express and defend the point of view, to feel an active subject of professional activity ${ }^{10}$.

The connotative component. By reflecting the active content of professional development, it characterizes its stability in the professional sphere at the level of skill. All behavioral acts of personality are dictated by values, meanings, motives, based on the

${ }^{9}$ Kucher V.A. (2011) Podkhody k opredeleniyu ponyatiy professional'noy ustoychivosti [Approaches to the definition of professional sustainability]. Pedagogical journal, no.11, pp. 83-96

${ }^{10}$ Kurljand Z.N. (2005) Stanovlennja pozytyvnoji Ja-koncepciji majbutnjogho vchytelja : Monoghrafija [Becoming a Positive Self-Concept of a Future Teacher: A Monograph]. Odessa: South. of sciences. center of APS of Ukraine (in Ukrainian) 
knowledge and understanding of their algorithms, which are carried out in real practice. The connotative component outlines the operational composition of the professional and his stability. The set of skills of professionally stable behavior and activity of the person is instrumental and technological. Professional stability of a specialist depends essentially on his ability to adapt to changing life circumstances and activities, to integrate into a new environment, to rebuild the type and nature of his professional behavior. It requires a creative and innovative thinking, freedom, flexibility, independence in staging, reconstruction and solving professional and business problems.

Reflexive and valuable component. Professional reflection can be seen as the ability to carry out systematic introspection with the subsequent creative activation of the professional activity. A specific feature of professional personality reflection is the inclusion of a time factor in the reflection process. It is necessary to distinguish between current (tactical) reflection, the subject of which is the solution of a specific professional task and perspective (strategic) reflection, the focus of which is on the desired level of professionalism. Reflection is closely related to the development of the dialogue personality of the specialist, plays an important role in the process of professional development of personality and the development of professional "Iconcept"11. Thus, the ability to reflect, the stability of value orientations, the readiness for productive communication and the establishment of trusting relationships (the level of development of the communication sphere and empathy) are important elements in forming the professional stability of the future specialist.

Regulatory and volitional component. The professionalism of a specialist depends on the degree of acquiring the modern content and modern means of solving professional problems, including the experience of professional self-regulation. Self-regulation is a

${ }^{11}$ Kurljand Z.N. (2005) Stanovlennja pozytyvnoji Ja-koncepciji majbutnjogho vchytelja : Monoghrafija [Becoming a Positive Self-Concept of a Future Teacher: A Monograph]. Odessa: South. of sciences. center of APS of Ukraine (in Ukrainian) 
volitional process by nature. K.K. Platonov identified one of its laws: the ability to self-regulation has direct connection with the level of manifestation of the main components of the will: purposefulness, perseverance, endurance, courage and discipline. Within the framework of the professional stability of the individual, the management of the emotional sphere is of particular importance, since this sphere can become a space for the emergence and realization of a value relation to the profession, since emotions taken in their integrity serve as motives of activity ${ }^{12}$.

Maddy's theory of the special personal quality of "hardiness" is quite interesting in the aspect of the study of the problem of professional stability formation of the future applied psychologist (Maddi, 1994). This theory arose in connection with the development of the problems of creativity of the individual and the regulation of stress. From his point of view, these problems are most logically related, analyzed and integrated within the framework of his concept of hardiness. By deepening the attitudes of inclusion, control and challenge (accepting the challenge of life), designated as "hardiness", one can simultaneously develop, enrich one's potential and cope with the stresses in his or her life path. In our literature, it is customary to translate "hardiness" as "stability" or "resilience" (D.A. Leontiev) $)^{13}$. The concept of "hardiness" reflects, from the point of view of S. Maddie and D. Koshab, the psychological vitality and efficiency of a person, as well as an indicator of a person's mental health. The personal traits of "hardiness" is emphasized by attitudes that motivate people to transform stressful life events. A person's attitude to change, as well as his or her ability to use the available internal resources to help effectively manage them, determine how much a person is able to cope with the difficulties and changes that he or she faces every day

12 Platonov K.K. (1996) Struktura i razvitie lichnosti [The structure and development of personality]. Moscow: Science (in Russian)

${ }^{13}$ Maddi S.R., Khoshaba D.M. (1994) Vynoslivost' i psikhicheskoe zdorov'e [Hardiness and Mental Health]. Journal of Personality Assessment. Vol. 63, no. 2. pp. 265-274. 
and with those that are of extreme nature. The first characteristic of hardy attitudes, according to S. Muddy, is "commitment" that is an important characteristic of oneself and the world and the nature of interaction between them, which gives strength and motivates a person to leadership, a healthy mindset and behavior. It gives the opportunity to feel meaningful and valuable enough to be fully involved in life and professional tasks, despite the presence of stressful factors and changes. Hardy is the attitude, conditionally called "control", that motivates to find ways to influence the results of stressful changes, as opposed to falling into a state of helplessness and passivity. This concept is very similar to the term "locus of control" by Rotter. In contrast to the fear of these changes, hardy that is called "challenge" helps one to remain open to the environment and society. It is in the perception of the personality of the event of life as a challenge and a test for oneself. To sum it up, we can say that "hardiness" is a special pattern of attitudes and skills that allow to transform change into opportunities. This is a kind of operationalization of the concept of "courage to be" introduced by $\mathrm{P}$. Tillich ${ }^{14}$. In addition to attitudes, "hardiness" includes such basic values as cooperation, credibility and creativity. Hardiness is a personality trait that allows to cope with distress effectively and is always in the direction of personal and professional growth. Thus, in the context of the formation of professional stability, based on the theory of S. Maddy, in the process of training a specialist should choose the dominant pattern of personality stress, creativity and the desire for actualization of internal potential.

Therefore, the professional stability of the psychologist is a psychological phenomenon, which includes an orderly set of value and semantic regulators that ensure the firmness of his subject position and emotional and volitional states. Its structure includes motivational,

${ }^{14}$ Maddi S.R., Khoshaba D.M. (1994) Vynoslivost' i psikhicheskoe zdorov'e [Hardiness and Mental Health]. Journal of Personality Assessment. Vol. 63, no. 2. pp. 265-274. 
cognitive, connotative, reflexive and valuable, regulatory and volitional components in their interrelation and interdependence.

\section{Psychological conditions of professional stability formation of the future psychologist: empirical receptions}

An empirical study was conducted among students of I-IV courses of the specialty 053 Psychology of Melitopol State Pedagogical University named after Bogdan Khmelnytsky.The sample was randomized to 140 students. The results of the implementation of the training program "Optimization of the process of professional stability formation of the future applied psychologist as a component of his positive self-concept" within the discipline "Workshop on group psycho-correction" showed that all the described types and means of the influence of gestalt technology are seen in self-regulation of students. This is evidenced by the changes that are objectively observed, as well as the mathematical and statistical processing and interpretation of the data obtained at the ascertaining and control stages of the study. To determine the significance of the changes that occurred after corrective work, we used the G-criterion and the Wilcoxon T-test. We hypothesize: H0: The predominance of the typical direction of shift between the obtained data is accidental. H1: The predominance of the typical direction of shift between the data obtained is not accidental. The structure of this training provides a block of activities aimed at developing the skills of emotional and volitional regulation of own activity and behavior of the future practical psychologists in general. In this regard, we have set ourselves the following main tasks:

- the formation of professional stability and, accordingly, emotional and volitional self-regulation should be connected with the purposeful formation of the process of self-regulation with the inclusion of the person in real activity. Purposeful formation should be preceded by the acquisition of knowledge about the holistic process of self-regulation of psychological activity, about its individual links and links between them (in the process of solving this problem we used the 
case-method and modern art-therapeutic technologies in order to expand and realize emotional experience);

- emotional and volitional mechanisms that implement the process of self-regulation or its individual units should be formed as a result of the analysis of the real tense circumstances, due to which they become necessary (in the process of solving this problem Gestalttherapy technique and technology of stress management were used);

- a person must learn to specify a leading goal in a system of derivative emotional characteristics manifested in such a unity that would provide flexible transitions from goal to result and vice versa (at this level, behavioral modeling techniques or cognitive and behavioral therapy are more commonly used). Particular attention is paid to forming a positive image of a stressful situation, learning of cognitive analysis of the situation, predicting behavior as appropriate, updating the skills of arbitrary relaxation and developing experience in applying techniques and formulas for constructive response in solving professional problems. The program is created in accordance with the principles of the concept of Accelerated Learning Theory and uses all the latest developments in the field of adult learning methodology ${ }^{15}$. In order to diagnose the level of emotional and volitional regulation, the following techniques were used: "The study of volitional selfregulation" (O.V. Zverkov and E.V. Eidman) and the questionnaire for the evaluation of neuro-mental stability "Prognosis-2". In the most general form, the level of volitional self-regulation refers to the degree of mastery of one's own behavior in different situations, the ability to consciously manage one's actions, states and motives. The level of development of volitional self-regulation can be characterized as a whole and separately by such traits of character as perseverance and self-control.

15 Varina H.B. (2018) Profesijna stijkistj jak integhratyvnyj komponent sanoghennogho potencialu osobystosti [Professional resilience as an integrative component of the sanogenic potential of the individual]. Suchasni zdorov'jazberezhuvaljni tekhnologhiji: kolektyvna monoghrafija [Modern Healthcare Technologies: A Collective Monograph]. Kharkiv: Hryhoriy Skovoroda Kharkiv National Pedagogical University, pp. 67-73 
Table 2

\section{The determination of the level of volitional self-regulation [made by author]}

\begin{tabular}{|l|c|c|c|c|c|c|c|c|}
\hline \multirow{2}{*}{$\begin{array}{c}\text { Indexes of } \\
\text { volitional self- } \\
\text { regulation }\end{array}$} & \multicolumn{3}{|c|}{ Before corrective work } & \multicolumn{3}{c|}{ After corrective work } \\
\cline { 2 - 9 } & \multicolumn{2}{|c|}{ High level } & \multicolumn{2}{c|}{ Low level } & \multicolumn{2}{c|}{ High level } & \multicolumn{2}{c|}{ Low level } \\
\cline { 2 - 9 } & $\begin{array}{c}\text { Absolute } \\
\text { quantity }\end{array}$ & $\mathbf{\%}$ & $\begin{array}{c}\text { Absolute } \\
\text { quantity }\end{array}$ & $\%$ & $\begin{array}{c}\text { Absolute } \\
\text { quantity }\end{array}$ & $\%$ & $\begin{array}{c}\text { Absolute } \\
\text { quantity }\end{array}$ & $\%$ \\
\hline $\begin{array}{l}\text { General self- } \\
\text { regulation }\end{array}$ & 62 & 44,3 & 78 & 55,7 & 110 & 78,6 & 30 & 21,4 \\
\hline Perseverance & 52 & 37,1 & 88 & 62,9 & 98 & 70 & 42 & 30 \\
\hline Self-control & 56 & 40 & 84 & 60 & 89 & 63,6 & 51 & 36,4 \\
\hline
\end{tabular}

According to the results of statistical data processing, we obtained the following indicators:

- after corrective work, the number of respondents of emotionally mature, active and independent persons increased by $34.3 \%$. They are distinguished by calmness, self-confidence, stability of intentions, realistic view, developed sense of own duty. As a rule, they reflect personal motives well, systematically realize intentions, are able to distribute efforts and are able to control their actions, have a pronounced social-positive orientation. Accordingly, the number of subjects with a low level of general self-regulation decreased by 2.6 times and are manifested in low reflexivity and reduced activity. Such personalities are characterized by impulsiveness and instability of intentions. This may be due to both immaturity and prominent sophistication of nature, that is not supported by the capacity for reflection and self-control.

- even after the implementation of the training program, the number of correspondents who are actively seeking to fulfill the planned activities has increased by $32.9 \%$. They are mobilized by obstacles on the way to the goal, but they divert alternatives and temptations, their main value is the action which was set up.

- after the correction program the number of emotionally stable future specialists who are well-versed in different situations increased by $23.6 \%$. The inherent peace of mind, self-reliance frees from fear of 
the unknown, increases readiness for perception of the new, unexpected and, as a rule, is combined with freedom of opinion, tendency to innovate and radicalism.

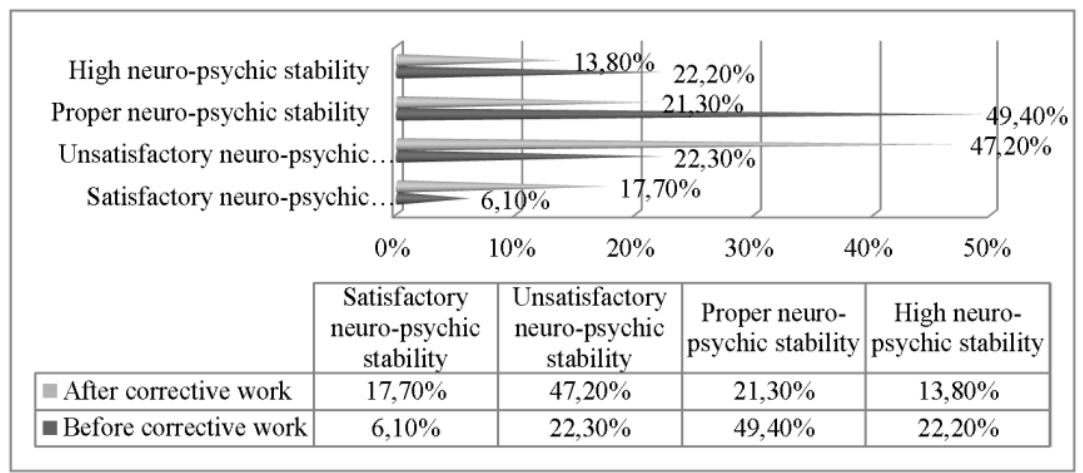

Fig. 3. The dynamics of development of neuro-psychic stability
of future applied psychologists [made by author]

The comparative analysis of the statistics revealed that:

- after corrective work the number of respondents with high neuro-psychic stability has increased by 1.6 times, so these students have a low probability of mental disorders and high level of behavioral regulation;

- after participation in the training program, the number of subjects with a low probability of neuro-mental breakdowns, adequate self-esteem and assessment of environmental reality increased by $28.1 \%$. Although single, short-term disturbances of behavior in extreme situations with considerable physical and emotional loads are possible;

- after corrective work, the number of respondents with satisfactory neuro-psychic stability, who may show moderate mental disorders in extreme situations, accompanied by inadequate behavior, self-esteem and / or perception of the surrounding reality, decreased by 2.1 times;

- after the introduction of psycho-correction training "Optimization of the process of professional stability formation of the 
future specialist", the number of correspondents with unsatisfactory neuro-psychic stability decreased, that is the tendency to disorders of mental activity at considerable mental and physical loads.

Psychological diagnosis of anxiety levels with the help of the Spielberger-Hanin questionnaire showed that the majority of students had a high level of situational anxiety (44\%) and a moderate level of personal anxiety (38\%). Persons belonging to the category of highanxiety tend to perceive the threat to their self-esteem and vitality in a wide range of situations and to respond to them with a expressed state of anxiety. Very high anxiety can be directly linked to the presence of neurotic conflict, emotional breakdowns and psychosomatic illnesses. Low anxiety, on the contrary, characterizes the condition as depressive, inactive, with low levels of motivation.

After corrective work, the dominant motive for studying at universities has changed.

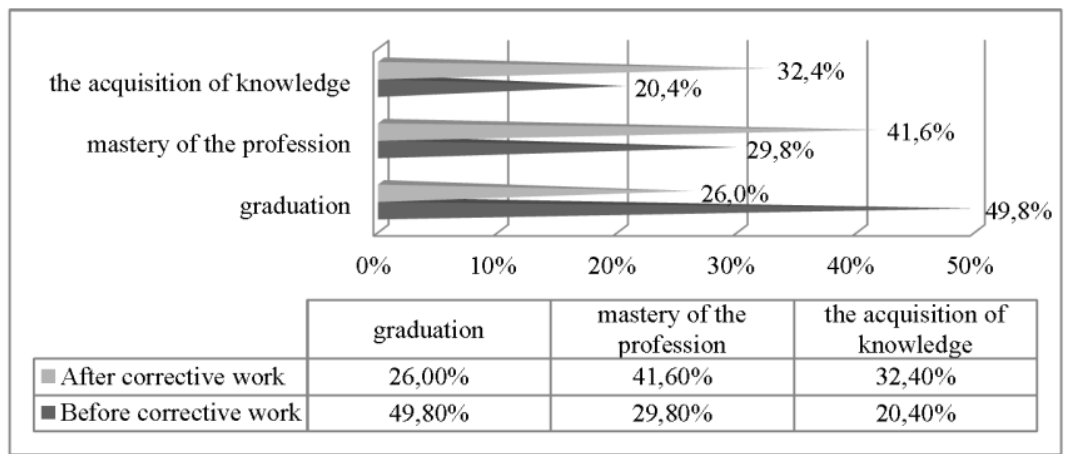

Fig. 4. The dynamics of change of motivational structure of education at universities [made by author]

The dominant motive of studying at universities for the majority of respondents $(41.6 \%)$ after correction work is the desire to master the profession and to develop professionally important traits, which is conditioned by the desire for professional self-realization and selfactualization. Also, the results of the correlation analysis revealed: at $\mathrm{n}=108$ typical shift is positive. There are 32 negative shifts. 
$G_{\tilde{n} \hat{e}}=\left\{\begin{array}{l}45(\rho \leq 0,05) \\ 42(\rho \leq 0,01)\end{array}\right.$ Gemp - the number of atypical shifts, ie Gemp $=32$ Gemp $<$ Gcr , so H0 is rejected, and $\mathrm{H} 1$ is accepted.

After the correction program, there were changes in the assessment of the ability to empathize and understand the thoughts and feelings of another.

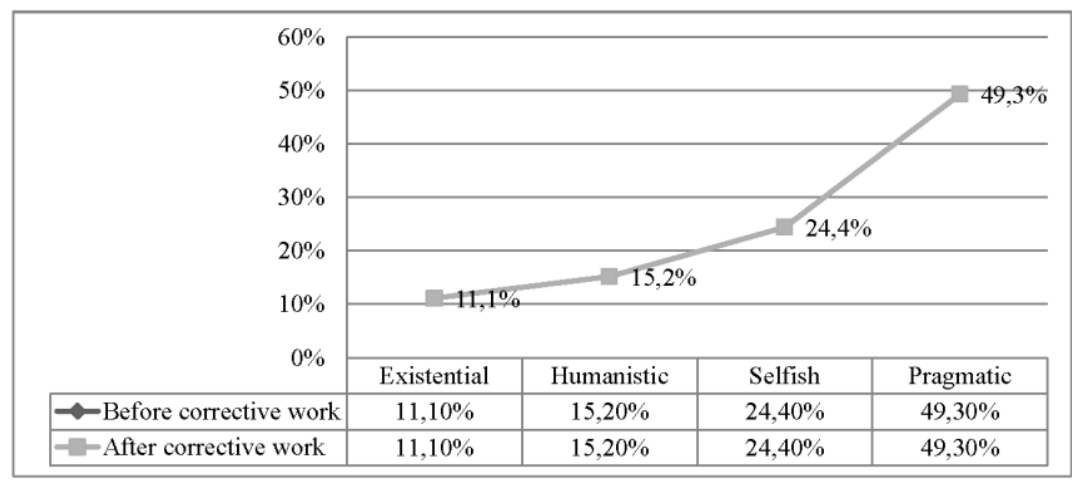

Fig. 5. The diagnosis of the level of emotional abilities of the future applied psychologist [made by author]

The average level of development of empathic abilities is $50,6 \%$. Under $\mathrm{n}=37$ typical shift is positive. No negative shifts were detected. $G_{c r}=\left\{\begin{array}{l}13(\rho \leq 0,05) \\ 10(\rho \leq 0,01)\end{array} \mathrm{G}_{\text {yii }}-\right.$ the number of atypical shifts, $\mathrm{G}_{\text {emp }}=0$ Gemp $<\mathrm{Gcr}$ so $\mathrm{H} 0$ is rejected, and $\mathrm{H} 1$ is accepted. The results of mathematical data processing show that changes in personality orientation are caused by a corrective program. The dominant was the humanistic type of orientation (39.8\%), and the increase in the number of students with existential orientation was by 2.3 times. Under $\mathrm{n}=118_{\text {typical }}$ shift is positive. There are 37 negative shifts. $G_{c r}=\left\{\begin{array}{l}50(\rho \leq 0,05) \\ 46(\rho \leq 0,01)\end{array}\right.$ Gemp - the number of atypical 
shifts, ie Gemp $=37 \mathrm{G}_{\mathrm{emp}}<\mathrm{Gcr}$, so $\mathrm{H} 0$ is rejected, and $\mathrm{H} 1$ is accepted.

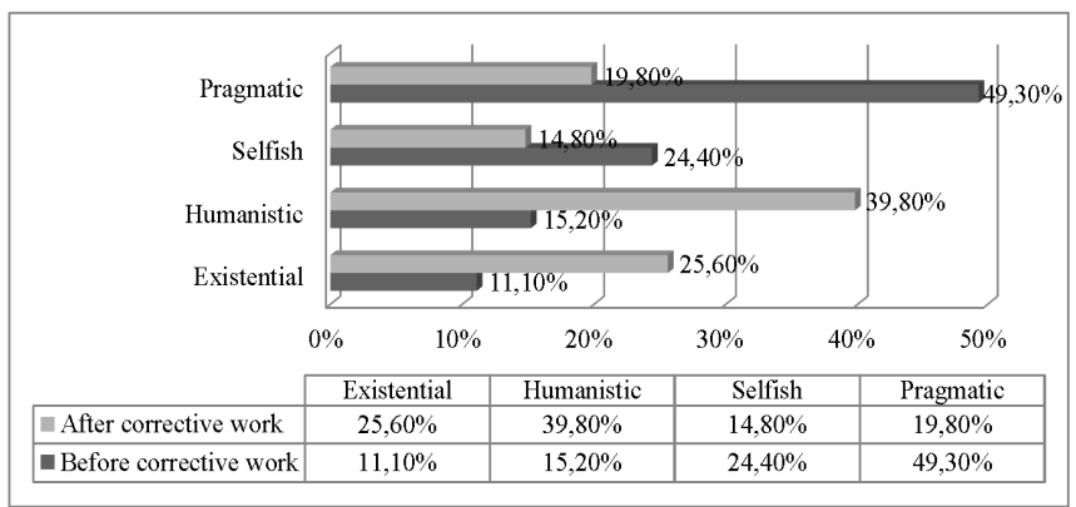

Fig. 6. The dynamics of professional orientation of the personality of the future applied psychologist [made by author]

As a result of the diagnosis of such mental states as anxiety, frustration, aggressiveness, rigidity it is revealed that the majority of students decreased the level of manifestation of these mental states (anxiety - by $18.5 \%$, frustration - by $25.4 \%$, aggression - by $27,8 \%$, rigidity - by $33.4 \%$ ).

Table 3

The definition of mental states of future applied psychologists (after corrective work) [made by author]

$\mathbf{N}=\mathbf{1 4 0}$

\begin{tabular}{|l|c|c|c|c|}
\hline \multirow{2}{*}{$\begin{array}{c}\text { Level of } \\
\text { manifestation }\end{array}$} & \multicolumn{4}{|c|}{ Mental states ( y \%) } \\
\cline { 2 - 5 } & Anxiety & Frustration & Aggression & Rigidity \\
\hline High & $10,4 \%$ & $10 \%$ & $14,8 \%$ & $7,4 \%$ \\
\hline Average & $52,4 \%$ & $54,2 \%$ & $40,5 \%$ & 38,9 \\
\hline Low & 37,25 & $35,8 \%$ & $44,7 \%$ & 53,7 \\
\hline
\end{tabular}


Under $\mathrm{n}=118_{\text {typical shift is positive. No negative shifts were }}$ detected. $G_{\tilde{n} \hat{e}}=\left\{\begin{array}{l}50(\rho \leq 0,05) \\ 46(\rho \leq 0,01)\end{array} \mathrm{G}_{\mathrm{emp}}\right.$ - the number of atypical shifts,

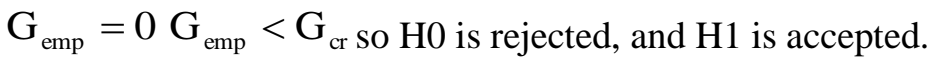

Analyzing the results, we can say that the psychocorrection program has helped to increase the level of professional stability and sanogenic potential as components of professional stability of future psychologists. Students have decreased levels of situational and personal anxiety, decreased levels of feelings of insecurity, anxiety, inferiority, anxiety about work, sensitivity to failure (reflects the "emotional" scale), increased level of flexibility of thinking and behavior, ability to change (reflects the "plasticity" scale).

\section{CONCLUSIONS}

The results of the study confirmed that the harmonization of the process of formation of professional stability as a component of the positive self-concept of the personality of the future applied psychologist in the conditions of the existing cultural and educational paradigm will be more successful provided with the introduction of a corrective training model in the educational process with the use of competence processes of self-knowledge and self-development. The development of professional stability in the educational environment and practical activities is a complex systematic process characterized by the interaction of processes of personal development, professionalization, socialization, interpersonal professional communication and professional interaction. Summarizing the various approaches to defining the concept of "professional stability", it is possible to define this concept as "the dynamics of stable states of man as a system in which he is able to identify external and internal negative influences in the process of professional activity with certain probability." Theoretical and pedagogical model of the formation of professional stability of future applied psychologists provides a cyclical, periodic and as needed (depending on the situation) repetitive process, which includes five stages: motivation to change; cognitive accumulation; reflection and individual self-determination; formation of appropriate 
competence, development of necessary skills; fixing and practical application. The main determinants of formation of professional stability of the future specialist in the modern cultural and educational space include the following factors: valuable and motivational, active and effective, evaluative and reflexive, regulatory, communicative and organizational, status and role. Inequality and diversity of their influence and change determines the individual traits of professional stability and sets the required variability of pedagogical interaction and organization of the educational process.

\section{SUMMARY}

The main components of professional stability in the context of the development of professionalism of the future applied psychologist are considered and investigated in the article. The main tool of influence of the psychologist, in addition to the acquired knowledge and skills, is his personality. Within the framework of theoretical and methodological analysis of the problem of professional stability of the psychologist, the following main components have been identified: cognitive, motivational, behavioral, emotional and volitional. On the basis of empirical research the ways and methods of professional stability formation of the future specialist are allocated. Introduced training "Optimization of the process of professional stability formation of the future specialist" includes methods of humanistic and cognitive and behavioral psychotherapy, as well as modern gestalt technologies. Summarizing the various approaches to defining the concept of "professional stability", it is possible to define this concept as "the dynamics of stable states of individual as a system in which he is able to identify with certain probability external and internal negative influences in the process of professional activity." Analyzing the results, we can say that the psychocorrection program has helped to increase the level of professional stability and sanogenic potential as components of professional stability of future psychologists. Students have decreased levels of situational and personal anxiety, decreased levels of insecurity, anxiety, inferiority, anxiety about work, sensitivity 
to failure, increased level of flexibility of thinking and behavior, ability to switch from one activity to another.

\section{REFERENCES}

1. Bernard B. (1991) Sodeystvie ustoychivosti u detey: zashchitnye faktory $v$ sem'e, shkole $i$ obshchestve [Fostering Resiliency in Kids: Protective Factors in the Family, School and Community]. Minneapolis : University of Minnesota (in English)

2. Chudnovskiy V.E. (1984) Nravstvennaya ustoychivost' lichnosti: psikhologicheskoe issledovanie [Moral stability of personality: a psychological study]. Moscow: Pedagogy (in Russian)

3. Krupnik E. P., Podymov N. A. (1999) Psikhologicheskaya ustoychivost' uchitelya kak uslovie preodoleniya innovatsionnykh bar'erov v ego professional'noy deyatel'nosti [Psychological stability of a teacher as a condition for overcoming innovative barriers in his professional activity]. World of psychology . no.2, pp. 175-178.

4. Krupnik E.P. (1995) Problema psikhologicheskoy ustoychivosti. Psikhologicheskie aspekty sotsial'noy nestabil'nosti [The problem of psychological stability. Psychological aspects of social instability]. Moscow: Moscow State Pedagogical University (in Russian)

5. Kucher V.A. (2011) Podkhody k opredeleniyu ponyatiy professional'noy ustoychivosti [Approaches to the definition of professional sustainability]. Pedagogical journal, no.11, pp. 83-96.

6. Kurljand Z.N. (2005) Stanovlennja pozytyvnoji Jakoncepciji majbutnjogho vchytelja : Monoghrafija [Becoming a Positive Self-Concept of a Future Teacher: A Monograph]. Odessa: South. of sciences. center of APS of Ukraine (in Ukrainian)

7. Maddi S.R., Khoshaba D.M. (1994) Vynoslivost' i psikhicheskoe zdorov'e [Hardiness and Mental Health]. Journal of Personality Assessment. Vol. 63, no. 2. - pp. 265-274.

8. Panok V.Gh., Umanecj L.I. (1999) Osobystistj praktykujuchogho psykhologha. Psykhoterapevtychna sytuacija. Osnovy praktychnoji psykhologhiji: Pidruchnyk [Personality of the 
practicing psychologist. Psychotherapy situation. Fundamentals of Practical Psychology: A Textbook]. Kiev: Libid (in Ukrainian)

9. Platonov K.K. (1996) Struktura $i$ razvitie lichnosti [The structure and development of personality]. Moscow: Science (in Russian)

10. Varina H. (2018) Psikhologicheskie aspekty ekspertizy emotsional'no-volevoy sostavlyayushchey professional'noy ustoychivosti budushchego prakticheskogo psikhologa [Psychological aspects of the examination of emotional-volitional component of professional sustainability of the future practical psychologist] Fundamental and applied researches in practice of leading scientific schools, no. 27(3), pp. 106-110.

11. Varina H.B. (2018) Profesijna stijkistj jak integhratyvnyj komponent sanoghennogho potencialu osobystosti [Professional resilience as an integrative component of the sanogenic potential of the individual]. Suchasni zdorov'jazberezhuvaljni tekhnologhiji: kolektyvna monoghrafija [Modern Healthcare Technologies: A Collective Monograph]. Kharkiv: Hryhoriy Skovoroda Kharkiv National Pedagogical University, pp. 67-73.

\section{Information about the author: Hanna Varina,}

Senior Lecturer at the Department of Psychology, Bogdan Khmelnitsky Melitopol State Pedagogical University 20, Hetmanska str., Melitopol, 72300, Ukraine ORCID ID: https://orcid.org/0000-0002-0087-4264 
DOI https://doi.org/10.36059/978-966-397-161-2/141-162

\section{AREAS OF ACADEMIC STAFF TRAINING IN UKRAINIAN DOMESTIC UNIVERSITIES (1863-1900)}

\section{Iryna Tamozhska}

\section{INTRODUCTION}

The development of independent Ukraine, democratization of the society, integration into the European and world community require reforming the national system of higher education, which should simultaneously cover all its components - goals, content, forms, technologies, monitoring of academic achievements.

It is impossible to solve these problems without the modernized and intensified training of the academic staff that is capable not only of generating new, relevant and promising directions of scientific and scientific-pedagogical activity, but also of innovative search for alternative personal development models for students of higher pedagogical educational institutions, academic support in students' individual educational trajectories, providing qualified guidance for young scientists, etc.

The aforementioned calls for the need to update the conceptual, theoretical and methodological foundations, content and directions of academic staff training for higher educational institutions, which is stated in the laws of Ukraine "On Higher Education" (2014), "On Education" (2017), "On Scientific and Scientific and Technical Activities" (2015), Regulations "On State Higher Educational Institution" (1996), Pedagogical Constitution of Europe (2013), etc.

Therefore, the development of the system of academic staff training in Ukraine is an integral part of the national state formation, an important factor of national and cultural revival of the country. The current progress of Ukrainian education into the European Higher Education Area and the European Research Area brings forth new tasks of training highly qualified teachers, modernizing the structure of 
educational and scientific qualification levels of the teaching staff in modern higher educational institutions.

Current reformation of the system of higher education in Ukraine requires not only theoretical understanding of new trends in pedagogical science, creative solution of the problem of training the most highly-qualified teaching staff, but also demands a more detailed research, reconsideration and implementation of the experience gained by the leading specialists and educational institutions in the past. We are mostly interested in the periods associated with the emergence of new concepts, approaches, the formation and development of universities. In the history of Ukrainian university education, it is the second half of XIX - the beginning of XX centuries. It is the time of spiritual and cultural revival of the Ukrainian, active reformation of the educational field, the establishment of academic freedoms and values. During this period the content, forms, models of university education underwent intensive development and transformation, which led to changes in the training of university academic staff in accordance with the requirements of the time.

Thus, the problem of scientific and pedagogical training has deep roots and is characterized by ambiguous processes of inheritance of its achievements. In this regard, the need arises for an unbiased analysis of the past experience, which makes it possible to objectively cover the genesis, content, directions of the activities of universities in order to solve the given problem, taking into account the peculiarities of the functioning of universities at different stages of higher education development in Ukraine, identifying factors of the effective work aimed at improving the professional qualification of the university academic staff, in order to creatively use the positive experience of the past in the current environment and prevent failures and defects of previous times.

The topicality and expediency of the research is further enhanced by the need to solve urgent social problems and overcome social and pedagogical contradictions:

- orientation of the modern higher education to the formation of a new generation of Ukrainian intelligentsia and the lack of a 
comprehensive analysis and generalization of the theory and practice of academic staff training at domestic universities;

- between the need for training highly qualified academic staff, capable of conducting pedagogical and research activity in the modern conditions of innovative social development, and insufficient research of the potential of university education as an environment for the professional advancement of scientists-educators;

- between the availability of historical and pedagogical assets revealing the theoretical foundations and the experience of scientific and pedagogical training of the university staff in Ukraine during a certain period of time, which have not lost their scientific and practical significance in modern conditions, and their insufficient application for the aforementioned training in the conditions of current educational reforms in Ukraine.

\section{Expanding the content and areas of academic staff training in the context of the current university reforms (1863-1883)}

Stage I (1863-1883) is a stage of expanding the content and areas of academic staff training in the context of the current university reforms related to the progressive organizational and management changes in the activities of the universities, spreading the levers of their influence in all spheres of university life. The general features of this stage lie in the fact that under the pressure of socio-political and socio-economic transformations of the $1860 \mathrm{~s}$, the restoration of the university autonomy, patterned after the one of 1804 , led to the intensification of the academic staff training.

The results of the scientific search showed that the approaches to the solution of the given problem were partially reflected in such regulatory documents as the Statute of the Imperial Russian Universities (1863), "Regulations on the examination for the title of a full student and academic degrees" (1864), "Rules on the terms and procedure for conducting examinations for the title of a full-time student and academic degrees" (1864), "Regulations on the awarding of academic degrees and titles" (1864). 
The abovementioned documents and the additions to them expanded the theoretical and methodological foundations of academic staff training for master's level in domestic universities: 1) the number of sciences, which determined the specialization of the master, was increased (up to 39); 2) the requirement to send printed copies of the dissertation according to a certain list one month before the public defense, as well as abstracts no more than 4 pages long, was introduced; 3) it was agreed to appoint two official opponents to review the dissertation within a six-month period, as well as to invite scholars of the related sciences from other universities for the public defense; 4) it was recommended to award a master's degree without any examinations to those applicants, who, through their scientific works, had gained worldwide recognition; 5) special honors (symbols) were approved for the those awarded master's degrees.

In the course of the scientific search it was found out that the measures taken contributed to positive changes in masters training. Thus, 39 masters were trained at St. Volodymyr University in the period from 1863 to 1883,34 - at Novorosiisk University, 40 - at Kharkiv University (in particular, 18 at the Faculty of Physics and Mathematics, 12 at the Law Faculty, 9 at the Historical and Philological Faculty). In total, for example, 84 master's degrees were awarded at Kharkiv University during the given stage.

The adoption of the Statute in 1863 marked a new stage in solving the problem of academic staff training, in particular in the implementation of academic staff certification at universities. On the one hand, there were no significant changes in the procedure for obtaining degrees in comparison with the previous statutes, on the other hand the Statute of 1863 laid the foundation for further documents, regulating the mechanism of getting a degree in the future. In particular, the statute included only the appropriate for the autocracy minimum of regulations on scientific staff training, without which it was impossible to ensure the normal functioning of the universities, designed to serve primarily the needs of the state apparatus in the diplomaed specialists. The title of a full-time student 
was restored, and the procedure for getting a doctoral degree was changed. They did not have to take any exams, it was sufficient to conduct the public defense of the thesis ( $\S 111)$. The procedure for awarding a master's degree was also somewhat simplified. An important innovation was granting the right to the university council to approve the degrees and titles, which was previously held exclusively by the Minister of Education.

The Institute of Professorial Scholarship Holders became an effective form of academic staff training and formation of university teaching. Its legislative registration took place after the enactment of the university statute in 1863. The category of professorial scholarship holders included young people who were sent abroad for further training, as well as graduates, who were awarded scholarships and remained at universities if their theses could be prepared on the grounds of the materials from national archives and libraries. The right to choose the candidates rested on the faculty and university academic councils according to such criteria as good health, inborn talent, scientific achievements, pedagogical abilities, practical experience, perseverance in independent work, mastery of foreign languages. For example, candidate of natural sciences M. Bunge was chosen as a professorial scholarship holder at Kyiv University in 1865. He was distinguished by his persistence in chemistry studying, thorough knowledge in the subject and the ability to use experimental research techniques.

Particular attention should be paid to the "Regulations on scholarships for young people who have completed university courses and were left at universities to train for the professorship" (1868), aimed at regulating the training of young scientists left for scientific training at domestic universities. According to the document, professorial scholarship holders of the abovementioned category were to be selected by the faculty among the young people who had graduated with honors from a university course and expressed a desire to remain with the university and work on the further development of science. University academic councils approved the nominations of the suggested scholarship holders by 
means of a closed cast of votes. The scholarship allowance was established at 600 karbovanetses per year.

A faculty member was appointed to guide a scholarship holder. After six months he had to make the faculty aware of the applicants' progress on the grounds of his academic achievements. During the second year of study, the scholarship holder had to take the master's degree exams or submit a thesis. If the applicant fulfilled that requirement, the faculty could apply to the university academic council with the request to extend the term of the scholarship payment for another six months or a year.

The scholarship holders left at universities were allowed to attend the lectures of the professors for free and to use all scientific tutorials. If the faculty considered it necessary to send a scholarship student to another Russian university for some time, the latter, under the agreement of the rector, was transferred to the supervision of the corresponding faculty of that university.

According to the statistics, which was regularly outlined in the reports of the Ministry of Public Education, we state the fact that the practice of enrollment of professorial scholarship holders aimed at their training for a professor acquired a wide spread occurrence in Ukrainian universities during the 1870 s - early 1880 s. For example, in the period from 1864 to 1884,77 persons were enrolled at St. Volodymyr University, including 22 at the Faculty of History and Philology, 19 at the Faculty of Physics and Mathematics, 17 at the Medical Faculty. 26 persons took teaching positions, i.e. one third of the total number of professors; 15 persons became teachers of the given university. Due to the activity of the Institute of Professorial Scholarship Holders, graduates of the history and philology faculties of Ukrainian universities, such as D. Bahalii, M. VladymyrskyiBudanov, M. Drahomanov, V. Ikonnykov, I. Lynnychenko, I. Luchytskyi, F. Mishchenko (St. Volodymyr University); V. Buzeskul, A. Butsynskyi, M. Drynov (Kharkiv University); G. Afanasiev, M. Kondakov (Novorosiisk University).

According to the "Rules on the business trips of scholarship holders for scientific purposes abroad" (1867), students studying for 
master's degree, after successfully passing the exams, acquired the right to go abroad in order to prepare the thesis. There was a specific instruction which determined the list of subjects the applicant had to study, which institutions and universities he had to attend, the names of professors, whose lectures he had to listen to, as well as the timing and list of reporting documents.

The similar practice of arranging foreign scientific trips was introduced for privat associate professors in order to further ensure the educational process and students' research work under the guidance of highly qualified academic staff. Thus, the right to such trips was obtained by the following professors of St. Volodymyr University: hygienist V. Subotin, zoologist O. Paulson, specialists in trade law P. Tsytovych, O. Zahorovskyi and I. Tarasov, historian V. Piskorskyi, philologist M. Mandes, pharmacist D. Rodzaievskyi, specialist in nervous and mental illnesses M. Lapinskyi, philosopher G.-R.I. Yakubanis and others. ' .

During their foreign scientific trips, privat associate professors and professors had the opportunity to get acquainted with the scientific achievements and methods of teaching disciplines, to conduct complex research, to complete theses and scientific articles.

It is established that at the stage under research, the development of the institute of privat associate professorship was further developed. The associate professors, who replaced the adjuncts under the 1863 Statute, were freelance teachers who gave lectures (receiving rewards from "special sums" of the university) and, as a rule, were subsequently taken on the staff in the case of a vacancy for a professor. Therefore, privat associate professors were a certain natural resource for replenishing the university professorship.

${ }^{1}$ Tamozhska I. V. (2018) Obozrenie prepodavanija v Imperskom universitete Sv. Vladimira na 1895/96 uchebnyj god [Scientific trips of privat associate professors from pre-revolutionary Ukrainian universities to higher educational institutions and educational institutions in Western Europe]. Liudynoznavchi Studii. Drohobych. Is. 6/38. pp. 307-319. DOI: https://doi.org/10.24919/2313-2094.6/38.120914 
In the course of the scientific search it is established that the Statute of 1863 actually substantiated the legal justification of the privat associate professorship, and also proved the need for its extension. Privat associate professorship was considered as the most important tool against "stagnation and apathy", "to support the competition" between professors and associate professors, which would become an effective means of scientific-pedagogical training of teachers, a powerful incentive for their scientific and pedagogical activity. Moreover, the position of privat associate professor was also created to eliminate the excessive seclusion of the professorial corporation, to create a competitive environment, and most importantly - as a reserve of future professors.

The Statute adopted in 1863 facilitated the search for compromises in higher education policy between university academic staff and the government regarding the introduction of the position of privat associate professor. It was noted in the comments to this legislative act that the privat associate professorship would contribute to the increase of the number of professors among the academic staff, and would also become an effective means of the department replacing. Thus, the prospects of solving the staff problems in higher education were connected with the development of the institute of privat associate professorship, which agreed with the world practice. However, the number of privat associate professors was increasing too slowly during 20-year period following the adoption of the Statute.

The analysis of the mechanisms of university staffing in the Russian Empire could not be complete without assessing the role of the privat associate professorship as an extremely important factor in improving the quality of the scientific and methodological process. Less than three years after the adoption of the university Statute in 1863 , C. Woldemar drew some conclusions about the prospects for its effectiveness. At the same time, he appealed to M. Pyrohov's opinion, who critically and reasonably revealed the main shortcomings in the system of training and certification of academic staff (in particular, about filling vacant positions in the departments), 
problems with the restriction of universities' autonomous rights in this aspect. University academic councils, being typical corporate associations, because of the nepotism as well as the protection of their interests, constantly made biased decisions when addressing the issues affecting inferior-ranked teachers, in particular, privat associate professors. It is not by chance that C. Woldemar emphasized the need for an unlimited number of privat associate professors in universities, because under the conditions of the Russian Empire a dictatorial approach to pedagogical science was observed, especially in personnel policy. Therefore, it was impossible to secure the progress of this institute ${ }^{2}$.

The 1863 Statute also allowed candidates to apply for privat associate professorship (under the 1843 decree, applicants were required to have a "master's degree"), which was a fundamentally important decision that opened privat associate professorship to the widest possible range of people (at the medical faculty, where there was a parallel system of degrees, even doctors were allowed to be admitted to privat associate professorship).

An increase in the number of associate professors was to become a "fresh-water force", "a natural means of filling professors" vacancies", "the nursery for professors". These statements fully coincided with M. Pyrohov's opinion, who argued for the need for mass involvement of privat associate professors in teaching as an important measure in the way of modernizing universities, creating an atmosphere of scientific search there.

${ }^{2}$ Woldemar C. (1866) Beiträge zur Geschichte und Statistik der Gelehrten und Schulanstalten des Kaiserlich Russischen Ministeriums der Volksaufklärung nach officiellen Quellen bearbeitet von C. Woldemar. III Theil. Wortlaut und Erläuterung der neuesten Statuten und Etats der unter dem Ministerium der Volksaufklärung stehenden Universitäten und Gimnasien sowie eines Reglaments über dieVolksschulen. St. Petersburg: Gedruckt bei Röttger und Schneider, 445 s.

3 University printing house (1864) Akt v Imperatorskom Har'kovskom universitete 17 janvarja 1864 goda [Regulations in Emperor Kharkov University of January,17 1864], Kharkov : University printing house. 37, 44, 7 p. 
In the course of the research it was found out that the university Statute of 1863 influenced the new "Regulations on the awarding of academic degrees and titles" created in 1864, which took into account many proposals by university professors aimed at changing the existing system of scientific staff certification.

According to the "Regulations", university academic councils had to develop rules on the term and procedure of examinations for academic degrees and titles. It was found out that the adoption of such rules involved intense struggle of progressive and reactionary forces, which occurred at all levels - in university academic councils, between the trustees and councils, and even inside the Scientific Committee itself.

Kharkiv University Council suggested that the examinee should provide the faculty with "full lecture notes of the main subjects of the exam", considering that "such an order would serve the faculty as one of the most effective ways of outlining the degree of ... a master's scientific education". The trustee of the Kharkiv Educational District believed that the exams had to be conducted in a regulated way as before, in accordance with the programs made by the faculty. Scientists from St. Volodymyr University also sent their proposals. For example, with regard to the "exam" on the candidate's degree, it was suggested that the time required to submit a written "reflection" should be increased (instead of three months allotted for the preparation of this type of work, a 6-month period was suggested). Scientists from St. Volodymyr University also suggested reintroducing exams for the degree of doctor of sciences, which had been cancelled before. They emphasized that the presentation and public defense of a thesis "... may not always be sufficient to assess the independence and thorough training of the examinee". The project made by Kharkiv University was adopted as a standard of the rules on the term and procedure of examinations for academic degrees and titles and recommended as an example to other universities.

According to the Statute of 1863, applicants for the position of privat associate professor were required to submit a dissertation 
provenialegendi ("to be admitted to lectures"), different from the thesis for a scientific degree, and publicly defend it. In terms of scientific complexity the provenialegendi was much simpler than a master's thesis. At the same time, it should not have been reduced to translation, to contain errors, but to have a level of minor but scientific work.

For applicants known to the university, the procedure of the submission and defense of the dissertation was often a formality. However, it was strictly obligatory for everyone. There were a few serious scientific works among the dissertations, several upgraded candidate's or even student's works, some applicants used their works written or even published long ago. For example, M. Drahomanov presented as a dissertation his former work "On Emperor Tiberius", in which he drew radical conclusions severely criticized by his opponents; V. Sokalskyi, a privat associate professor at Kyiv University, also used his student work. Specially written works were far less defended as provenialegendi dissertations.

The defense could be held at any university, and the resulting teaching rights were extended to all higher educational institutions. Thus, Kharkiv University candidate N. Kuplevaskyi was sent to Kyiv and defended his dissertation there, then he returned to Kharkiv and began teaching as a privat associate professor. In other cases the place of the defense was determined by the willingness of the university to subsequently employ a privat associate professor. For example, A. Borovykovskyi, candidate of Law Faculty at Kharkiv University, presented his provenialegendi at his university, and then moved to Moscow and defended his dissertation there.

As a rule, faculties did not make high demands for the level of the dissertation, because even the "deadly" reviews did not mean an unavoidable failure. However, the admission of a new member to the teaching corporation was a difficult process, so defending the thesis as a condition of admission could become a heated debate.

It was found out that Kharkiv University had stricter requirements for the dissertation. According to the conclusion of the Faculty of Law (1870), the dissertation provenialegendi could not be 
equated with the candidate's work; the work had to show a thorough knowledge of the subject and literature, soundness and clarity of judgment. Consequently, there were a few cases of failed defenses at that faculty: out of 16 dissertations presented from 1863 to 1884, four were declared unsatisfactory.

The university Statute of 1863 introduced conducting two trial lectures for candidates for privat associate professorship, in case "their teaching abilities were not well-known", which made it more difficult for outside candidates to access the institute.

However, for those who passed this test, conducting the trial lectures proved to be an extremely important moment at the beginning of their teaching career. The topic of one of the lectures was chosen by the candidate himself, the other one was appointed by the faculty at a special meeting. If the dissertation defense was a more formal procedure aimed at convincing the university council of the author's competence and erudition, the trial lectures were intended to reveal the candidate's pedagogical abilities. The dissertation was prepared in advance, its content was adjusted. The topic of one of the two trial lectures was determined by the faculty to test the applicant's ability to quickly collect, summarize and present the material in the form of a lecture. Moreover, trial lectures were given to an audience of students - the privat associate professor's future trainees, who he had to make interested in his subject. Trial lectures were an effective method of teachers' scientific and pedagogical training, testing of their professional knowledge and skills in practice. Some of the professors of the relevant faculty could also attend the lectures. Thus, Professor O. Kistiakivskyi visited the trial lectures of M. Kuplevaskyi (a privat associate professor at St. Volodymyr University in 1877-79).

According to the professors' statements, the lectures on the topic chosen by the candidate himself, were, on the contrary, characterized mainly by the scientific style of presentation, the large number of references to sources and literature, including foreign and modern ones, as well as the use of the results of the candidate's own research. Among the disadvantages of the lectures on the topic 
assigned by the faculty, we could mention literary techniques, rhetorical skills and broad generalizations.

Entrance examinations for the title of privat associate professor, introduced at the universities at the stage under research, were a serious trial for young scientists. Not all candidates who formally met the requirements were successful. At the same time, by order of the Minister of March 8, 1875, a legislative framework was created to involve privat associate professors in more intensive teaching. Since then, cases of appointing privat associate professors to vacancies in the departments had been recorded.

The simplification of the procedure for obtaining scientific degrees, the elimination of the doctoral exam in accordance with the "Regulations on the awarding of academic degrees and titles" (1864) significantly intensified the scientific work and teaching activity in domestic universities, which had a positive impact on academic staff training. During the decade (1863-1874), about 180 master's and doctoral theses were defended at Kharkiv, Kyiv and Novorosiisk universities. The significant feature of the stage lied in the fact that scientific certification became a purely internal affair of a particular university, which, in turn, contributed to transforming the academic councils into the "highest authority institutions" in terms of awarding scientific degrees. For example, from 1863 to 1883 the academic council of St. Volodymyr University awarded the master's degree and doctorate to 113 persons, including the master's degree to 39 applicants, doctor's to 74, while only 80 applicants got the degrees in the first 29 years of the university's operation. In the period from 1866 to 188421 persons obtained the doctoral degree and 24 persons were awarded the master's degree at Novorosiisk University.

\section{Evolutionary development of theoretical and methodological foundations for academic staff training in domestic universities (1884-1900)}

At the second stage (1884-1900) the basic principles of realization academic staff training in the domestic universities were 
regulated by the provisions of the University Statute of 1884, which remained practically unchanged till the end of the century, supplemented only by ministerial circulars.

It is established that the Statute of 1884 made some changes to the procedure for awarding scientific degrees. The provisions of Chapter Two "Trial" of the third part of the Statute abolished the candidate's degree and introduced a two-stage system: master-doctor, which were awarded at all faculties except medical, where there was only a doctor's degree.

On the basis of the Statute of 1884, the postgraduate, who passed the exams and conducted two trial lectures (one at his own request, the other at the appointment of the faculty), acquired the right to teach in the rank of a privat associate professor, which allowed "diagnosing the applicant's ability and suitability to the future teaching career in advance".

According to the provisions of the Statute, the greater role was played by the trustee, who at his or her own order could convene the council, the board, the assembly of faculties; be present at their meetings, appoint deans of faculties, introduce extraordinary professors to the Minister of Public Education for their promotion, and monitor private associate professors' teaching. The Minister of Public Education himself now appointed the rector, who became the "presiding person". In accordance with the provisions of the Statute of 1863, the Rector was obliged to report to the University Council in case of a "teaching irregularity". On the contrary, the Statute of 1884 gave the rector the right to make instructions, warnings and reproofs.

In the course of the research it was found out that the new university statute significantly complicated the procedure for awarding degrees. More attention was paid to purely formal issues - taking exams, preliminary consideration of theses at the faculties, etc. According to the Statute of 1884, the number of degrees decreased significantly. There were now two degrees (master's and doctor's) in all faculties, except medical, the rest were awarded diploma of I or II level. In addition, the Statute of 1884 significantly increased the Ministry's control over the process of scientific staff certification. 
Thus, the Minister could appoint the examiners, who were to be present at the examinations for awarding a scientific degree on the corresponding field of science.

In 1884, the Ministry of Public Education developed new "Rules" for the functioning of the Institute of Professorial Scholarship Holders, according to which the head of the department or the dean of the faculty were responsible for searching scholars. The former were obliged to take all necessary measures to train promising young people in the best way possible, above all at those departments which were considered to be major in the faculty, or which experienced the lack of staff.

Applicants could become professorial scholarship holders if they met the following requirements: a model certificate with excellent marks in ancient languages (for candidates of historical and philological or legal sciences) or in mathematics and physics (for candidates of physical and mathematical or medical sciences); command of foreign languages to be able to study professional literature and master lecture material; high marks in major subjects of the department; their own scientific works; perfect moral qualities; the ability to reasonably express their opinions, good health. From now on, the Ministry of Public Education decided where the scholarship holder's internship would take place (in Russia or Europe) and appointed scientific advisors who could make changes to the academic curriculum according to the candidate's inclinations and needs; clear deadlines were set for the applicants to submit a plan or instruction for faculty-designed classes, as well as a certificate of political credibility.

Despite the strengthening of government control, 24 scholarship holders became teachers at Kharkiv University during 1884-1894. The Institute of Professorial Scholarship Holders was particularly effective at St. Volodymyr University, where 87 scholars were trained during the decade.

The innovation in solving the personnel problem at the stage was the creation of the institute of full-time associate professors according to the German model as "center of future forces of universities' scientific corporation". However, this institution, 
introduced by the university Statute of 1884, did not root deeply in the Russian Empire due to unfavorable conditions for potential applicants for this title, so it was soon abolished.

The Statute of 1884 significantly changed the nature of the privat associate professorship. "Professors of other higher educational institutions, as well as persons who gained popularity with their scientific works ..." could become privat associate professors. In fact, privat associate professorship was an opportunity for scholars to continue teaching on a freelance basis.

The number of privat associate professors fluctuated every year. Thus, at the beginning of 1888 there were 31 privat associate professors at St. Volodymyr University, and in September of the same year only 24 . They conducted classes at 10 vacant departments, only at the department of trade law there was a professor of civil law. The faculties obliged the privat associate professors to acquire scientific and pedagogical knowledge, and then decided whether they could be trusted to examine students, what reward they should get and even the priority of rewarding.

After 1884, the conditions for admission to the privat associate professorship became more flexible in the whole. The most significant change in obtaining the rank of a privat associate professor was the abolition of the mandatory defense of the dissertation provenialegendi, which by that time had become a formality and did not cause any difficulties.

The charter of 1884 abolished the position of associate professor. Associate professors known for their erudition were either promoted to extraordinary professors, or, "if their teaching was found to be useful", they were left in the position of associate professors temporarily, with an annual extension. With the abolition of the associate professorship, the hierarchy of positions looked like this: freelance privat associate professors, full-time extraordinary and ordinary professors. This system left the only possible option for those who would like to teach in anticipation of a full-time position. It was a privat associate professorship. Therefore, the position of a privat associate professor became the main way to attain the professorship. 
That fact marked an important change in the tasks of the privat associate professorship - "it transformed from the alternative and financially unprofitable option of a career start it became the only opportunity to gain a foothold at university". The Statute of 1884 also maintained the tradition of involving privat associate professors in conducting lectures at vacant departments on a temporary basis. However, it had to be permitted by the Minister, the privat associate professor got the reward, which could not be more than a half of an ordinary professor's salary. Such replacement should not have taken more than a year.

The tasks of the privat associate professorship were finally established: training for the professorship through pedagogical practice, stimulation of competition among teachers aimed at increasing their scientific and teaching level, maximum expansion of the curriculum of the academic disciplines, radical revival of the very scientific spirit of universities.

The study of scientific sources and archival materials made it possible to find out that a large number of teachers from domestic universities were thoroughly trained in privat associate professorship. In this regard it is worth mentioning bright graduates of the history and philology faculties of Ukrainian universities, whose names have become the true pride of national science: D. Bahalii, M. Vladymyrskyi-Budanov, S. Hohotskyi, M. Dashkevych, M. Drahomanov, V. Ikonnikov, O. Kistiakivskyi, I. Luchytskyi, F. Mishchenko, I. Lynnychenko, G. Pavlovskyi and others (St. Volodymyr University); V. Buzeskul, A. Butsynskyi, M. Drinov, I. Sreznevskyi and others (Kharkiv University); M. Kondakov, G. Afanasiev and others (Novorosiisk University).

Due to the intensification of the research activity of masters and privat associate professors, which was one of the main factors for improving the professional level, their role significantly increased in the educational process of universities. In addition, teachers participated in the work of scientific societies. This, in particular, is testified by the study of archival materials at Kyiv University: privat associate professors participated in the work of the Kyiv Law Society 
(O. Zhylin), the Joint-Stock Company (B. Shyshkovskyi; Paris); XVII International Medical Congress in London (M. Strazhesko); Kiev Syphilidological and Dermatological Society, Society of Kyiv Physicians (S. Tomashevskyi), Historical Society of France (V. Piskorskyi), conducted advanced training courses for teachers and doctors.

University teachers published a great deal of articles in the University Newsletter. For example, Master of Police Law I. Tarasov presented his impressions of being in educational institutions of Germany, Austria-Hungary, Switzerland, and also outlined the activity of loan societies, cooperative structures in five issues of the edition for $1879^{4}$. An essay by A. Hren about the history of the Caucasus isthmus, which analyzed the literary and archival materials on the history of the Caucasus, and also described the geographical position of this region, was published in two issues in $1895^{5}$.

Academic staff of domestic universities also included professors invited from other universities of the Russian Empire. However, the tendency gradually emerged to develop the scientific and pedagogical potential of Ukrainian universities due to the improvement of their own graduates' training. It is significant that at the end of XIX century $43 \%$ of the faculty members of Kharkiv and almost half of St. Volodymyr University were alma mater students, which proved the efficiency of masters and privat associate professors training at domestic universities.

Since 1884, the regulations on trial lectures had undergone significant changes, and conducting such lectures had ceased to be a

${ }^{4}$ Tarasov I. T. (1879) Dva goda na Zapade s uchjonoju cel'ju [Two years in the West for a scientific purpose]. University Newsletter. № 1. pp. 28-50; Tarasov I. T. (1879) Dva goda za granitseyu [Two years abroad]. University Newsletter. № 5. P. 326-360; Tarasov I. T. (1879) Dva goda za granitseyu [Two years abroad]. University Newsletter. № 7. pp. 463-499; Tarasov I. T. (1879) Dva goda za granitseyu [Two years abroad]. University Newsletter. № 8. pp. 539-566.

${ }^{5}$ University Newsletter (1895) Obozrenie prepodavaniya $\mathrm{v}$ Imperskom universitete Sv. Vladimira na 1895/96 uchebnyy god [Teaching review St. Vladimir Imperial University for 1895/96 academic year] (K.). № 9. pp. 1-72. 
prerequisite for some candidates. Overseas trips "for a scientific purpose" remained an effective means of academic staff training.

At the stage under research, university academic councils became an intermediate instance of educational affairs between the trustee and the faculties. At the same time, the Statute of 1884 retained the right of academic councils to approve scientific degrees and to apply for the opening of scientific societies at the university.

A significant drawback of this stage was the formalization of the procedure for awarding scientific degrees and the absorption of academic councils' functions by other management structures, which negatively affected academic staff training.

\section{CONCLUSIONS}

The greatest positive influence on the solution of the problem of academic staff training in the domestic universities during the researched period was made by the Statute of 1863 , when due to the democratic reforms of the 1860s universities acquired broad powers and the right to independently determine the development strategy of the university, in particular, to increase the scientific and pedagogical level of the teaching staff. The main official documents, in accordance with which academic staff certification was conducted in Ukraine during the researched period, included: university statutes, developed by universities, regional rules on the procedure and terms of conducting examinations for academic degrees and the "Regulations for awarding academic degrees". They set out the general procedure for awarding scientific degrees, a more detailed regulation of the procedure for getting a degree was outlined in the published "Regulations".

The analysis of scientific sources and archival materials gives the grounds for the conclusion: if the direct and obvious task of the privat associate professorship - training for the professorship coincided with the task performed by the institute of professorial scholarship holders, the fundamental difference and peculiarity of the privat associate professorship was the combination of the privateassociate scientific and pedagogical activity by privat associate 
professors as the Ministry of Education and the universities tried to provide an opportunity for privat associate professors to not only give lectures on their own private programs that supplemented the core course, but also and to take part in teaching alongside with the professors.

The activities of Kharkiv, Kyiv and Novorosiisk universities aimed at the organization of academic staff training involved: 1) preliminary interview with candidates; 2) convening faculty meetings in order to develop the current rules on the terms and procedure of masters training, to carry out the certification of applicants on major and optional subjects; 3) conducting the procedure of postgraduates' and privat associate professors' theses public defense, selection of postgraduates and privat associate professors for internships abroad and hearing their reports; 4) conducting trial lectures, etc.

In accordance with the theoretical and methodological principles of the research, academic staff training in Ukrainian universities during the given was studied as a complex and continuous process that took place under the influence of socio-political, socioeconomic as well as cultural and educational determinants.

\section{SUMMARY}

The experience of academic staff training in St. Volodymyr University, Kharkiv University and Novorosiisk University during 1863-1900 is summarized. The stages of the solution of the abovementioned problem within the specified chronological framework are singled out: I stage (1863-1883) - a stage of expanding the content and areas of academic staff training in the context of the current university reforms, II stage (1884-1900) - a stage of evolutionary development of theoretical and methodological foundations for academic staff training in domestic universities. The legislative environment, peculiarities and directions of academic staff training in Ukrainian universities after the adoption of the university Statute of 1863 are outlined. It is determined that the regulatory and legal framework that regulated academic staff training and 
certification in Ukrainian universities during the researched period included laws (university statutes, decrees) and by-laws (orders, decrees, circulars, instructions, rules).

\section{REFERENCES}

1. University printing house (1864) Akt $\mathrm{v}$ Imperatorskom Har'kovskom universitete 17 janvarja 1864 goda [Regulations in Emperor Kharkov University of January,17 1864], Kharkov : University printing house. $37,44,7 \mathrm{p}$.

2. Woldemar C. (1866) Beiträge zur Geschichte und Statistik der Gelehrten - und Schulanstalten des Kaiserlich Russischen Ministeriums der Volksaufklärung nach officiellen Quellen bearbeitet von C. Woldemar. III Theil. Wortlaut und Erläuterung der neuesten Statuten und Etats der unter dem Ministerium der Volksaufklärung stehenden Universitäten und Gimnasien sowie eines Reglaments über dieVolksschulen. St. Petersburg: Gedruckt bei Röttger und Schneider, $445 \mathrm{~s}$.

3. University Newsletter (1895) Obozrenie prepodavaniya $v$ Imperskom universitete Sv. Vladimira na 1895/96 uchebnyy god [Teaching review St. Vladimir Imperial University for 1895/96 academic year] (K.). №9. pp. $1-72$.

4. Tamozhska I. V. (2018) Obozrenie prepodavanija v Imperskom universitete Sv. Vladimira na 1895/96 uchebnyj god [Scientific trips of privat associate professors from pre-revolutionary Ukrainian universities to higher educational institutions and educational institutions in Western Europe]. Liudynoznavchi Studii. Drohobych. Is. 6/38. pp. 307-319. DOI: https://doi.org/10.24919/ 2313-2094.6/38.120914

5. Tarasov I. T. (1879) Dva goda na Zapade s uchjonoju cel'ju [Two years in the West for a scientific purpose]. University Newsletter. № 1. pp. 28-50.

6. Tarasov I. T. (1879) Dva goda za granitseyu [Two years abroad]. University Newsletter. № 5. P. 326-360.

7. Tarasov I. T. (1879) Dva goda za granitseyu [Two years abroad]. University Newsletter. № 7. pp. 463-499. 
8. Tarasov I. T. (1879) Dva goda za granitseyu [Two years abroad]. University Newsletter. № 8. pp. 539-566.

\section{Information about the author: Iryna Tamozhska,} Candidate of Pedagogical Sciences, Associate Professor at the Language Training Department 1 of the Institute of International Education for Study and Research, V.N. Karazin Kharkiv National University in Ukraine 4, Maidan Svobody, Kharkiv, 61022, Ukraine ORCID ID: orcid.org/0000-0003-0865-2380 
DOI https://doi.org/10.36059/978-966-397-161-2/163-185

\section{ASSESSMENT AS ONE OF THE FACTORS \\ OF THE IMPACT ON THE CHILD'S \\ SELF-ESTEEM FORMATION DURING THE SCHOOL ADAPTATION PROCESS}

\section{Nataliia Vydolob}

\section{INTRODUCTION}

First of all, the modern Ukrainian elementary school is focused on humanizing the educational process and forming a successful personality, by revealing the best qualities of the individual. As never before, the Ukrainian government pays special attention to elementary school. Since last year, in all regions of Ukraine, first-graders have started their educational process with the New Ukrainian School program. In this article we analyze elementary school education only in the context of NUS (New Ukrainian School).

This new educational program is different from the previous one. A key aspect of the program is the personality of each child. In particular, NUS is aimed at educating a conscious citizen with a set of intellects, not only a cognitive one. Also, the program is focused on revealing the personality of each student, his creative potential, critical thinking etc. and acquiring competencies on the basis of humanism, as a special principle of understanding a person's place and purpose in the world.

An important message of this program is the focus on the formation of competence. Primary education standards that include imperative outcomes of study are approved at the state level. Eleven of them are defined: fluent in the state language, ability to speak their mother tongue (if different from the state language) and foreign languages, mathematical competence, competence in natural sciences, engineering and technology, innovation, environmental competence, information and communication life, learning civic and social 
competences, cultural competence, entrepreneurship and financial literacy ${ }^{1}$.

One of the key psychological tasks of the new educational program is the formation of students' self-esteem. Formative assessment is used as a new form of evaluation that promotes adequate self-assessment. From now on, it is not an assessment of specific knowledge on a specific period of time, but a long process of observing a child's educational progress.

Until recently, the assessment of elementary school students was characterized by selectivity and fragmentation, which is not always objective (does not take into account the child's well-being at a specific time or other reasons that affect the quality or quantity of the result). Thus, assessment focuses only on the result within a short period of time, and further replenishment of knowledge is no longer considered. This situation affects the formation of self-esteem and quite often in a downward direction - low self-esteem.

Assessment of knowledge transforms into the assessment of the student himself and, in the same time, other classmates are labeled as "low-achiever", "high-achiever", etc. For example, when a child which is good at artistic disciplines does not show excellent results in mathematics, it leads to the assessment of her as incapable of learning in general. Such external evaluative judgments are transferred to selfevaluation, which is manifested in inadequate self-esteem.

Self-esteem plays an important role in the process of knowing the world and man as himself. It is necessary in self-realisation, selfaffirmation and identification of a person in society. Without it, it is impossible to find out one's place and destination in the world. Selfesteem is affected by other people's thoughts, beliefs, and assessments of personality. The influence of external evaluations largely forms both self-esteem and the nature of social activity. Social and personal roles, conditioned by status and rank, and the level of social and individual mobility, depend on self-esteem. In the professional sphere,

${ }^{1}$ Derzhavnyi standart pochatkovoi osvity (2018) [State standard of primary education]. 
the nature of human activity also depends on the level of self-esteem: from career to adaptation, from the generator of ideas to the executor; in the family - from authoritarianism to egalitarianism; in communication with people - from sociability to loneliness etc.

It is worth to mention that this study is an attempt at a conceptual approach to the formation of elementary school children self-esteem in the process of adaptation to school through pedagogical techniques, including formative assessment.

\section{The Positive Impact of a Competence Approach in the Educational Process on the Children' Self-Esteem Formation in Elementary School}

Domestic education is one of those social institutions that must first respond to qualitative changes in social life. It must not only adapt to social variability and integrate into the European educational space, but also be guided by predictive scientific results regarding the challenges of the future. Because, children need to adapt to the present situation and they should be prepared for the future social challenges.

However, despite frequent changes in political or economic life, the school should focus on a humanistic approach to its educational programs.

Elementary school provides the child with basic knowledge of specific disciplines. It is worth to mention that critical thinking skills and emotional intelligence emerge during this period. These skills influence the formation of self-esteem. It is important not to ignore the child's age-related psychological characteristics during the studying process.

The combination of adequate self-esteem and acquired competencies turns into an opportunity for successful realization of personality in life. The modern world requires the individual to be active, dynamic, be able to work in a team on equal rights, to become a leader in rapidly changing situations, to adapt to the variability of the proposed circumstances, without losing his personality and creativity. 
At the World Economic Forum in Davos, members discuss how to solve humanitarian issues and identify current personal skills to be successful in a professional environment. So for 2015 the top skills were defined: complex problem solving, coordination with others, people management, critical thinking, interaction, negotiation, quality control, service orientation, judgment and decision making, active listening, creativity. For 2020 - complex problem solving, critical thinking, creativity, people management, coordination with others, emotional intelligence, judgment and decision making, service orientation, interaction, negotiation, cognitive flexibility ${ }^{2}$.

The Future of Jobs Report 2018 provides the Emerging skills that modern man need. These skills are: creativity, originality and initiative, analytical thinking and innovation, active learning and learning strategies, technology design and programming, emotional intelligence, critical thinking and analysis, leadership and social influence, complex problem-solving, systems analysis and evaluation, reasoning, problem-solving and ideation ${ }^{3}$.

All these indicators need to be taken into account while planning the educational and upbringing process in primary school, both in order to acquire competencies for the learners and to form an adequate self-esteem. Competent approach in studying process also contributes to the development of personality and the formation of individual self-esteem.

A competent approach in the early grades of the new Ukrainian school involves the syncretism of pedagogical and psychological theories and practices. If pedagogy is more focused on the development of the individual by technological ways of applying a certain methodology in teaching, then psychology always focuses on the subtle mental organization of each person - his or her psyche in general, and formation of self-esteem in particular. Together, they are able to form a person who is able to value themselves and the world around them with dignity.

\footnotetext{
${ }^{2} 10$ kliuchovykh navychok do 2020-ho (2016, January 25) [10 key skills by 2020].

${ }^{3}$ TheFutureofJobsReport 2018
} 
The issue of forming an adequate self-esteem should be raised during the first days of studying in school. Self-esteem of the person is an assessment of the person himself, his capabilities, guided by the generally accepted system of values in society. For a six-year-old child the habitual environment changes and many new social groups, people, appear in his life. And here it is important not to break the personality, but to develop. Self-esteem is a key aspect here. It depends on her self-confidence and desire for further development. Even a cheerful, responsible child may end up in a new social group, not being accepted by others. Therefore, a competent approach not only focuses on the acquisition of new knowledge or mastering the skills of arithmetic, writing, etc., but also promotes the disclosure of the child's inner world. This contributes to the formation of adequate self-assessment and assessment of the environment.

Psychologists turn to the problem of self-esteem continuously. This issue is not limited by space or time frames. Society is changing and requires a constant rethinking and reassessment of reality in order to harmonize the individual. Addressing the problem of self-esteem from an early age will allow a person to perceive the world as it is and will help to choose the best options for the proposed life scenarios without fear and exaggerate their own efforts.

W. James was the first to introduce the concept of "self-esteem" and "self-image" into the structure of personality. He paid particular attention to such a factor of self-esteem as a sense of satisfaction. Everyone has a relatively constant average limit of well-being that is completely independent on their objective conditions of satisfaction or dissatisfaction. Therefore, a person who finds himself in adverse conditions of life may be in an unbroken state of complacency and, conversely, when a person who deserves universal respect and success with his actions feels distrustful of his own strength.

He noted that a normal causative agent of well-being for humans is their favorable or unfavorable position in the world - its success or failure. Man, as an empirical personality, has wide limits, because through his own efforts he always succeeds. There 
are individuals who have a high status in society, are financially secure, surrounded by friends, and respectful. Such personalities will not treat themselves with the distrust with which they treated themselves when they were young. And a person, who has had downs one by one, becomes desperate in the middle of the life way. That person is overwhelmed by painful self-doubt, and surrenders even when the circumstances do not exceed its capabilities. However, they do not believe in their strength because of low selfesteem ${ }^{4}$.

It is worth to remember this while forming the current competencies. Because topical skills will change in a few decades under the influence of social, economic, political, cultural, religious challenges, and the formation of adequate self-esteem in childhood will allow us to perceive the changing world, evaluate the proposed life variations and adapt in the new social space. Inadequate selfesteem (too low or too high) will lead to a sense of cognitive dissonance.

Different representatives of psychological science interpret the meaning of the concept in their own way. However, everyone is convinced that adequate self-esteem is the key to a happy life. K. Rogers says that self-esteem has influenced a person's behavior since childhood. The adequacy of self-esteem depends on the choice of the circle of communication and the choice of profession. The essence of man is expressed through self-esteem, which is a reflection of the true essence of personality. Behavior is conditioned by self-esteem, expresses the true essence of "I". Exploring the structure of "I", he concludes that the inner essence of human is expressed through selfesteem, which is a reflection of the true essence of personality ${ }^{5}$.

Manner of behavior depends on self-esteem (superficial, proud or quiet, invisible, or tolerant, humane, active). The life position

${ }^{4}$ W. James. Psychology: BrieferCourse. N.Y.: H. Holt\&Co, 1893.

5 Rogers K. (1994) O stanovlenii lichnosti. Psikhoterapiya glazami psikhoterapevta [About formation of personality. Psychotherapy through the eyes of a psychotherapist]. 
depends on it in direct proportion: from the passive consumer to the active civic and the desire to learn new or materialize their ideas. As we can see, the competencies of communication and creativity are always relevant and need to be formed from childhood.

Adequacy of assessment leads to the choice of approaches to solving current problems, and to social and professional activity. $\mathrm{K}$. Rogers draws attention to the fact that when behavior is conditioned by self-esteem, it expresses the true essence of personality and brings satisfaction to itself and external success.

A child who has just come to school goes through an adaptation process. This is where the dissonance arises: the demands of society and the demands of satisfying child's own needs seek common ground. There is a process of learning a new social experience, adapting to new patterns of behavior and acquiring new social competencies (communication, interaction, etc.).

At the time, Piaget introduced his concept of cognitive development of the individual. He divides this period into four stages: sensomotor, preoperative, specifically operative and formally operative, and describes each with inherent personality characteristics that are consistently formed in the process of socialization $^{6}$.

Sensomotor stage is typical for children up to two years old. The child can only perceive what is sensory. If a thing is out of its sense, it does not exist. During this period, it is difficult to determine the psychosomatic manifestations of the body, because in this period physiological needs are important (the first stage of the Pyramid of A. Maslow): breathing, warmth, food. Up until the age of seven, the child learns the language. This period is characterized by selfcenteredness. Only her narrow world of relative people is comfortable for her.

The period from seven to eleven years (accounting for elementary school) J. Piaget identifies as the development of an

${ }^{6}$ Piaget J. (2001) Teoriya, ehksperimenty, diskussii [Theory, experiments, discussions]. Moskow: Gardariki. 
important cognitive property of the individual - the acquisition of abstract logical concepts. The next is a formally operational period from eleven to fifteen years - of understanding and distinguishing abstract ideas (good and evil, beautiful and ugly, fair and unfair, etc.). However, the Swiss psychologist notes that all individuals undergo the first three, but not everyone - formally operational. It all depends on the quality of school education and upbringing.

That is why it is so important in the new elementary school to introduce such techniques that would help focus the child in the process of life on the actual life experience, and not on the past or future, on the formation of categorical apparatus such as "sense of life", "values", "life goals", etc. This allows both to understand the child and to feel its inner world, and to direct its social activity in the humanistic vector, and to promote the formation of adequate selfesteem.

It is worth mentioning another psychologist in the field of humanistic direction, who is convinced that a person will get more joy in life if he evaluates solely his traits and actions, and not worry about the assessment of his so-called "I". This is A. Ellis. In his opinion, a person's assessment of himself as being is a logical solution to the problem of self-worth. "If a person needs to value him, then it is better for him to proceed from such a reliable norm as his life or existence. Then, according to this rule, she can quite rightly decide: "I am good not because I am very successful in doing something, and not because some people praise me, but simply because I live and I exist". When a person accepts his positivity from the point of view of existence or life, obviously, he accepts himself in almost every manifestation that he can. According to this rule, she will not be able to find positivity only if she dies" $"$.

7 Ehllis A.(2002) Gumanisticheskaya psikhoterapiya: Ratsional'noehmotsional'nyy podkhod [Humanistic Psychotherapy: A Rationally Emotional Approach] Moskow: EHKSMO-Press. pp. 26. 
A. Ellis has repeatedly emphasized that a person should not tolerate a general assessment of his specific actions (depending on the situation, the same act can be interpreted as positive and negative), skills and competences, etc. This is all situational in a particular place and time.

The formation of self-esteem depends on the sum of opinions, other people's assessments and their own real successes, achievements in the process of human life divided by the level of requirements that a person sets to himself.

The first thing, that is important for a child to know, is that life itself is the highest value. In the future, if he has to evaluate himself, his importance, then he should know that it is better to use such a reliable norm as his own life or existence. Then he will be able, in accordance with this norm, to justifiably decide: "I am not good because I am doing something very successfully, and not because some people praise me, but simply because I live and I exist. When a person accepts this positivity, it is obvious that he accepts himself in all his manifestations, which may take place during life.

Next, you need to teach the child to define himself and others positively in relation to his existence and life. Learn to think by the formula: I live, and I am good because I live. And everyone has the right to live and it is also good. This will solve many humanitarian problems in the future. The realization of the value of life leads to compromise but not to forceful solutions of conflict situations.

The key to understanding the importance of self-esteem is never to evaluate itself based on the results of unsuccessful or victorious deeds. Because, a negative mark in the exam does not mean a person as a loser. This is only an experience from which we must draw the correct conclusion. The exam can be retaken, or it is possible to start learning something else or to engage in another matter that is to your liking, etc. A man is neither good nor bad; he is what he is. He exists, possesses certain skills and abilities, talents, etc., but there is no need to move from assessing these opportunities and abilities to a holistic assessment of himself. 
Evaluation and emotional attitude of the person to himself is important in the formation of self-consciousness. At the primary stages of schooling the attention should be paid to the formation of adequate self-esteem. Such self-esteem will contribute to a critical attitude to oneself and to reality; the distinction between the true and the proper, the real and the illusory, the objective and the subjective; comparing one's life position with social prescriptions, norms, taboos. This, in turn, will foster the necessary skills for successful living, which have been defined by the global top community for more than a decade. This is critical thinking and emotional intelligence.

The pedagogical and psychological aspects of educational activity in general and primary school in particular should always be considered in unity. Modern society has set itself the goal, through a new vision of the school, to form a harmonious personality with the possibility of maximizing the realization of intellectual and creative potentials in society. Therefore, we are not only teaching certain skills, but are focused on developing personal competences that will allow child to feel comfortable in the world and, moreover, to perceive it as an aggregate of the same individuals, to adequately assess himself and others, his skills and knowledge and to realize them.

The new Ukrainian school offers various techniques that contribute not only to the acquisition of new knowledge and a positive psychological climate, but also to the formation of competencies required for modern man. These are the techniques of the "Morning Circle" - which allows everyone to feel part of the team and to understand that this team is one. And "you and I - we" to feel the other children and to understand that they are all different, but they have much in common. This contributes to fostering tolerance as the basis of humanism. "Compliment" is to see other people's positive traits and, at the same time, to form a positive attitude towards that person. When children learn to respond sincerely with a compliment for a compliment, an idea is formed: everyone in this world is different, but everyone is worth something and has every right to realize her potential within the possible social 
space, among others. These techniques have been analyzed in the context of our child's adaptation to school earlier ${ }^{8}$. Let's just mention that they contribute to the formation of an adequate individual's selfesteem of the.

However, another very important factor in the formation of selfesteem is the adequate assessment of the child's knowledge and success in the studying process, especially in elementary school.

\section{Formative Assessment as a Way of Forming Adequate Self- Assessment in Pupils in the Process of School Adaptation}

The modern educational space, especially in elementary education, has undergone significant and intense changes over the last year. For the second year in a row, first graders go to a new school (new in content). The significant difference with the previous one is the education of a conscious citizen, a free personality, with a set of eight intellects but not one cognitive. These educational systems are focused on revealing the personality of each student, their creative potential, critical thinking, emotional intelligence, etc., and acquiring the competences for successful life in various situational manifestations.

In 2019, the International Foundation "Renaissance" and the Ukrainian Center "Assessment of Educational Quality", with the support of the Ministry of education and science of Ukraine and the American councils of international education, prepared a "Strategy of development of Educational Assessments in the field of general secondary education in Ukraine until 2030" 9 .

8 Vydolob N. (2019) Psykhosomatychni reaktsii orhanizmu na protses adaptatsii ditei molodshoho shkilnoho viku [Psychosomatic reactions of the organism to the process of adaptation of younger children]. Naukovyi visnyk khersonskoho derzhavnoho universytetu. Seriia "psykholohichni nauky». [Scientific Bulletin of Kherson State University. Psychological Sciences Series] Vol. 3, pp. 49-56.

9 Stratehiia rozvytku osvitnikh otsiniuvan u sferi zahalnoi serednoi osvity $v$ ukraini do 2030 roku (2019) [Strategy for the development of educational evaluation in the general secondary education in ukraine by 2030] 
This document is not about the age- psychological features of a child's psyche. We find here a clear understanding of the new approach of final assessment in the general secondary school education system. However, after carefully analyzing the document, in particular section 1.1, which deals with the subject, tasks, statuses and goals, forms of evaluation, we can come to the following conclusion. A competency-based approach gives freedom of choice not only to the learning process but also to the final assessment of the education recipients upon graduation. "Grading at elementary school should be carried out using a wide variety of forms and formats of tasks. And it should provide the possibility of cyclically changing the relevant forms and formats from year to year" ${ }^{\text {"10 }}$.

This confirms our hypothesis about the positive impact of assessment on the formation of positive self-esteem of the elementary school children in the new Ukrainian school. First, we know about the individual characteristics of each person, which depend not only on education, but lay by nature. Not everyone can be a talented artist or writer because artistic and figurative thinking and reflection are run into all personalities in different ways. Therefore, assessing the writing skills of all students in one form - writing a text will not be an objective assessment. There are other forms of testing these skills: writing letter types, promotional booklets, announcements, newspaper articles, reviews, etc. And everyone can show themselves in more than one kind of work.

This approach allows both freedom of choice and responsibility for it, and does not demean a child who can write competently in business style, but is unable to fantasize and spell it in accordance with all linguistic norms. And the main cause of self-esteem is the humiliation itself. In addition, all these forms and formats of tasks are familiar to the child.

As for mid-term assessment, it has also been implemented in a competency-based manner with the new educational program. This is

${ }^{10}$ The same, p. 13 
called a formative assessment. Now, this is not an assessment of specific knowledge on a specific period of time, but a long process of monitoring the educational progress of the child. Until recently, the assessment of elementary school students was characterized by selectivity and fragmentation, which is not always objective (does not take into account the child's well-being at a specific time or other reasons that affect the quality or quantity of the result).

I. Kobernik calls the formative assessment a resource for development. She identifies five key aspects of formative assessment. Firstly, the teacher directs his or her activity to discover the potential of each child, not conforming to a certain standard. Secondly, "a formative assessment should not contain any NO, no negative judgment or criticism. Formative assessment diagnoses areas that need improvement and helps improve them." Thirdly, such an assessment "cannot consist of a score, a number, a letter, or just one word. Parents should be provided with an obligatory explanation, advanced category, or verbal characteristic ...". Fourth, there are no special controls. This is an evaluation of the student process, not an outcome. And fifth, "the attitude of the concept of 'assessment' in the country should change and how quickly this will happen it depends on the teacher. Teachers and parents who are accustomed to the standard assessment system need to be reformatted.

The life period of a child, during elementary school, is characterized by natural psychological and physiological features of its development. The emotional state of the child is unstable. She is unable to control her own emotions on her own, unable to concentrate on one activity for a long time. The first-grader, on the one hand, shows independence, because many times before he has heard: "you are almost a schoolboy", "what you will do if you go to school", "no one will spoil you at school", etc. But that also force the child to consider the school period particularly adult, and the realities of life lead to dissonant conclusions. The child stays a child, but adults expect other behavioral markers. And if in addition to all this the child receives a negative evaluation for "ugly" spelling of letters, then we 
have a qualitative leap in change of self-esteem, but not in the positive way, but on the contrary - in the negative way.

Therefore, it is so important to give the child in the early years of education all the necessary conditions for its successful development and adequate perception of reality. The adequacy of selfesteem depends on it, which in the future will allow making successful decisions in different situations of life and the ability to draw conclusions from them. Formed adequate self-esteem in a school allows a real correlation of their rules of behavior to those established by society and framed by culture. Such a person is in constant search for a real vision of himself, without too much reassessment, but also without unnecessary criticality of his social and individual activity in communication, behavior and other activities.

In psychology, there is a constant thesis: "Our self-esteem is a kind of cognitive schema" that summarizes past personal experiences and organizes new information regarding this aspect of "I".

We should remember that the beginning of school life is a period of change (physiological, mental and social). New social groups in which a child is six or seven years old require her to be independent, accountable and to be guided by the new rules, adhere to norms, and be perceived by another team.

During the same period, there is a crisis of seven years. Social norms, which up to six years were assimilated, began to be used as a self-assessment. At the age of six a child enters a new life, and "age of six years is characterized by a largely undifferentiated overestimation of self-esteem. By the age of seven, it is differentiating and decreasing slightly. There is no previous assessment of comparing oneself with others. Non-differentiation of self-esteem leads to the fact that a child of six to seven years considers the adults' "one-action" assessment as an assessment of their personality in general" $"$.

${ }^{11}$ Shaida N. P., Shaida O., G. Kryza mizhosobystisnykh stosunkiv ta yii vplyv na osoblyvosti rozvytku samootsinky ditei [The crisis of interpersonal relationships and its impact on the development of self-esteem in children] Problems Of Extreme And Crisis Psychology. vol1 pp. 325-333 
The previous section focuses on the fact that no one can ever evaluate the result of a single action as an assessment of a person in general. Again, we remember A. Ellis. A person must be taught not to evaluate himself, not to measure his qualities, not to play "egogames", but to solve the problem of self-worth. That is, a person must define himself positively in relation to his existence and life. Learn to think by the formula: I live, and I'm good because I live.

However, if a person wants to solve the problem of value, then it is better for him to avoid evaluating himself at all. That means, a person is not good or bad, he is as he is. He exists, possesses certain skills and abilities, talents, etc., but should not go from assessing these capabilities and skills to assessing himself. "Then, excluding selfesteem, ego-playing in competition for" positivity "with other people, you may ask yourself", What do I really want in life?". And you can try to find the job or tasks that you really like and enjoy doing it ${ }^{12}$.

That is why formative assessment positively influences the formation of elementary school student's self-esteem. Each child has his own temp of study, different preparation for school, his own physiology and so on. And marking them all with one sign - the grade for an intermediate result in the learning process leads to the formation of inappropriate behavior. More often it is underestimated.

For example, one child will be able to write one letter in accordance with the rules for three lessons and another for six. And after the sixth lesson he will show the best result. However, in the first three sessions, she was rated low. He transferred this assessment to self-esteem. In the future, he has already learned that he cannot spell correctly.

It is worth bearing in mind that the crisis of this age is characterized by peculiarities in behavior and perception of reality: the loss of immediacy of behavior. There is an imbalance between desires and actions about the expediency of their actions. The child tries to

12 Ehllis A.(2002) Gumanisticheskaya psikhoterapiya: Ratsional'noehmotsional'nyy podkhod [Humanistic Psychotherapy: A Rationally Emotional Approach] Moskow: EHKSMO-Press. P. 32. 
live up to the expectations of adults, demonstrating even the positive qualities that are not peculiar to them. Children with low self-esteem often experience feelings of inferiority, as a rule, they do not realize their potentials, that is, inadequate low self-esteem becomes a factor that hinders the development of the child's personality.

As a result, in such a situation, we have low self-esteem, disillusionment, and negative attitudes towards studying. In the future, society receives an unrealized personality with an adaptive lifestyle.

Instead, formative assessment allows you to see all the features of each child and help discover their talents, unleash their abilities and, most importantly, do not lower their self-esteem and lose the desire to learn. Formative assessment makes it possible to evaluate the learning process of students rather than the temporary result of memorizing certain material, and therefore makes it impossible to combine knowledge assessment with self-assessment (inadequate selfassessment).

Obviously, the accumulation of external imperatives about personal existence is accompanied by emotional instability throughout the period of the child's adaptation to school. In this regard, it is normal that self-esteem changes from time to time.

The norm in self-esteem is its relatively constant state. It is possible to characterize positively relatively stable self-esteem, that is, one that changes its content, height, adequacy, depending on the success in learning, the emergence of new age characteristics. When self-esteem remains unchanged despite new life circumstances, it becomes inadequate. Inadequate self-esteem can be both overpriced and too low. In both cases, it leads to bias in both the perception of the world and self-perception, as well as the relation of man with the world. It is expressed in the idealized, or, conversely, undervalued image of one's self, the irrational use of one's capabilities, and the irrational perception of reality. In any case, whether overestimated or lowered self-esteem, the process of self-regulation is disturbed, selfcontrol is disturbed, and the level of conflict in the communication process increases. If self-esteem is overstated, conflicts arise due to neglect of other people, intolerance of their thoughts and beliefs, 
manifestations of arrogance. With low self-esteem, because of excessive criticality, there is a demand for oneself and an even greater demand for others, focusing on mistakes and shortcomings.

Self-esteem is formed on the basis of perception and assessment of one's own activity and behavior. At a young school age, the individual first realizes not the activity, but the fact of its implementation. Only gradually does the student separate himself from what he is doing and become aware of himself as a subject of activity and a carrier of certain qualities. Therefore, the generality of thinking about oneself can be considered as an age characteristic of the development of students' self-esteem.

The established and habitual lifestyle of a young school-age child is changed to a demanding and full of limitations. Timeframes for performing certain actions are now becoming the norm. The state of anxiety that the student does not know or do not know (not yet developed writing skills, reading) stimulate the biological component of the body to switch on the protective mechanisms: reduced body resistance, disturbed sleep, appetite, fever, exacerbated chronic diseases. Only the narrow world of relatives is comfortable for the child, where they are not expected to have certain behavioral rules.

A feature of formative assessment is the observation of the learning process of the child throughout the school year and involves the formation of students' ability to self-assess their own progress. Such a rating system gives the child confidence by emphasizing his or her best sides rather than pointing out mistakes, fostering better results and, at the same time, not being afraid of their own mistakes. She understands that everyone learns from mistakes, that from the first time it will not be perfect for any job, that learning is a normal process in a person's life and if you work hard, you will have the right result. At the same time, the child herself observes the dynamics of learning and sees it.

Formative assessment positively influences the further desire to learn, to develop, to independently search, to develop creative abilities, without fear of doing something wrong. Since the evaluation of a correctly or incorrectly solved example does not label a student 
"excellent", "bad", etc., and does not affect the self-esteem of the individual, and this assessment is just another link in the chain of competencies for its successful functioning. The success of the adaptation period depends on the assessment of the child at school, especially at the initial stage. The result of a slow adaptation is an annoyed, frustrated personality with fear of an unknown future and the perception of the new as negative. Conversely, the sooner the adaptation period will pass and the child will begin to perceive the school environment as his own with all his behavioral markers, normative codes, and values. And the evaluation system will only contribute to the formation of competencies that are vital for its dayto-day implementation, and we will eventually receive a harmonious personality with a set of opportunities to be happy in this world and in this time.

\section{CONCLUSIONS}

A human tries to understand its purpose in the world, the limitations of its own entity, or its own self-being, to find out the essence of existence throughout the span of its own life. The problem of forming self-esteem of the individual in the context of awareness of reality has been relevant for many years. Since neither man nor the world stands still, they have developed independently, and depend on one another bound by the laws of nature and society. A human being is constantly in search of itself and its place in the world: materially, spiritually, and socially. A person must be prepared for these changes and adapt to a new social being. Naturally, the concepts of "personality" and "society" are interconnected. It is difficult to imagine a person outside of society, since it is impossible. The personality of a human being creates in the process of social interactions. This is an integral set of qualities, features formed under the influence by cultures of society and specific social groups, in particular, in the process of organising common activities in a communicative way. The process of personality formation is continuous, and does not stop. It can only be more or less intense, depending on age, the frequency of social changes, life position and 
many other factors. The concept of "society" means a combination of individuals united by a common culture (which creates common values and rules), territory and social identity. A personality is a component of a society that does not exist outside of it. And the sole purpose of personality creation is to be a part of society, to find a place for oneself in a system with a set of values and norms. Therefore, it is very important to teach child that social change is a normal phenomenon.

Theoretical research in the psychological and pedagogical context is reduced to the following provisions: First, self-esteem is a measure of the individual, with his or her set of competencies by generally accepted social norms and values. So, as a child of sixseven years of age enters a new phase of their physiological, psychological and social life, the first days of school should be as comfortable as possible. Her living space is filled with new people and new rules. Successful adaptation to school life and adequate self-esteem depends on both the psychological and physiological state of the child's health. Second, self-esteem depends on selfconfidence and a desire for further development. Even a seemingly cheerful, a responsible child may end up in a new social group and not feel comfortable there. Therefore, the elementary school education program should not only focus on learning new skills or mastering the skills of arithmetic, writing, etc., but also help to uncover the inner world of the child. This will allow the formation of adequate self-esteem and assessment of the world. Since modern social life requires a person of constant activity, dynamism, communication, ability to adapt to new social changes, etc., adequate self-esteem is one of those indicators, which together with the acquired competences will help to adapt to society. As we can see, from the research of the world community, the professional orientations of the future and the forecasts about the necessary skills to realize oneself in the profession, the top skills change under the influence of social, economic, political, cultural, religious challenges. Therefore, it is necessary to form adequate self-esteem for the child from an early age, which will allow them to evaluate 
their abilities and suggested life variations and successfully adapt to the new social space.

Third, as we analyzed the normative documents in the field of elementary education and made its own observation, it is worth to mention that the competent approach in the early grades of the new Ukrainian school involves the syncretism of pedagogical and psychological theories and practices. A competent approach in the NUS curriculum also promotes the development of personality and the formation of an individual's self-esteem. In order to understand the child, his inner world and promote his social activity, communication techniques have been introduced in NUS. This "Morning Circle" - allows everyone to feel part of the team and to understand that this team is one group, "I and you - we" - to feel the other children and to understand that they are all, although different, but unites them much in common, to identify with a new group, to cultivate tolerance as the basis of humanism, a "compliment" - to see other people's positive traits and, at the same time, to form a positive attitude towards them. Fourth, the competency approach in NUS is used not only for the learning process but also for the intermediate and final evaluation of the educational recipients. This confirms the hypothesis about the positive impact of assessment in the new Ukrainian school on the formation of adequate self-assessment of young school children. Formative assessment positively influences the further desire to study, to develop, to independently search, to develop creative abilities, without fear of doing something wrong. Since the evaluation for a correctly or incorrectly solved example does not bear the mark of "excellent", "bad", etc., and does not affect the self-esteem of the individual, but it is just another link in the chain of competencies for its successful functioning. Therefore, assessment is an important factor in influencing the self-esteem of a child in the process of adaptation to school in general, and formative assessment has a positive effect on the formation of adequate selfesteem of young school children. 


\section{SUMMARY}

The study of the influence of formative assessment on the formation of students' self-consciousness is dictated by the demands of time. Modern society has set itself the goal, through a new vision of the school, to form a harmonious personality with the possibility of maximizing the realization of intellectual and creative potentials in society. Formative assessment has been introduced into the educational field for only the second year and needs careful attention in terms of scientific interpretations of both pedagogy and psychology. The relevance of the topic lies in the theoretical substantiation of the importance of the new approach in evaluating the results of educational activities introduced by the new Ukrainian school. The result of the study is a theoretical justification for the impact of formative assessment on the elementary students' self-awareness. The new education curriculum is based on a competency-based approach. It is called formative assessment. From now on it is not an assessment of specific knowledge, on a specific period, but a long process of observing a child's educational progress. Formative assessment focuses on the process rather than short-term results. It promotes the disclosure of children's abilities and the formation of objective selfesteem from early school age. Solving the problem of self-esteem from an early age will allow a person to perceive the world as it is and not to transfer the evaluative judgments about the results of his activity to an evaluation of himself.

\section{REFERENCES}

1. 10 kliuchovykh navychok do 2020-ho (2016, January 25) [10 key skills by 2020]. Retrieved from https:// www.eduget.com/news/10_klyuchovix_navichok_do_2020-go-907

2. Derzhavnyi standart pochatkovoi osvity (2018) [State standard of primary education]. Retrieved from https://zakon.rada.gov.ua/laws/show/87-2018-\%D0\%BF

3. Ehllis A.(2002) Gumanisticheskaya psikhoterapiya: Ratsional'no-ehmotsional'nyy podkhod [Humanistic Psychotherapy: 
A Rationally Emotional Approach] Moskow: EHKSMO-Press. (in Russian)

4. Fridman L.M., Kulagina I.YU. (1991) Psikhologicheskiy spravochnik uchitelya [Psychological reference teacher] Moskow: Prosveshchenie. (in Russian)

5. James W. (1893) PsychologyBriefer Course. N.Y.: H. Holt \& Co.

6. Kobernyk I. (2 Травня 2018) Otsiniuvannia v Novii ukrainskii shkoli: resurs dlia rozvytku zamist vyroku [Assessment at the New Ukrainian School: A Resource for Development Instead of Sentencing] Retrieved from https://nus.org.ua/view/otsinyuvannya-vnovij-ukrayinskij-shkoli-resurs-dlya-rozvytku-zamist-vyroku/

7. Maslow A. (1970) Motivation and Personality (2nd ed.) N.Y.: Harper \& Row

8. Piaget J. (2001) Teoriya, ehksperimenty, diskussii [Theory, experiments, discussions]. Moskow: Gardariki. (in Russian)

9. Rogers K. (1994) O stanovlenii lichnosti. Psikhoterapiya glazami psikhoterapevta [About formation of personality. Psychotherapy through the eyes of a psychotherapist]. Retrieved from http://psylib.org.ua/books/roger01/index.htm

10. Shaida N. P., Shaida O., G. Kryza mizhosobystisnykh stosunkiv ta yii vplyv na osoblyvosti rozvytku samootsinky ditei [The crisis of interpersonal relationships and its impact on the development of self-esteem in children] Problems Of Extreme And Crisis Psychology. voll pp. 325-333. Retrieved from http://nuczu.edu.ua/ sciencearchive/ProblemsOfExtremeAndCrisisPsychology/vol1/33.pdf

11. Stratehiia rozvytku osvitnikh otsiniuvan u sferi zahalnoi serednoi osvity $v$ ukraini do 2030 roku (2019) [Strategy for the development of educational evaluation in the general secondary education in ukraine by 2030] Retrieved from http://www.euroosvita.net/prog/data/attach/6133/190523_strategiyaosvitnih-otsinyuvan_utsoyao.pdf

12. The Future of Jobs Report 2018 (2018) World Economic Forum. Retrieved from http://www3.weforum.org/docs/ WEF_Future_of_Jobs_2018.pdf 
13. Vydolob N. (2019) Psykhosomatychni reaktsii orhanizmu na protses adaptatsii ditei molodshoho shkilnoho viku [Psychosomatic reactions of the organism to the process of adaptation of younger children]. Naukovyi visnyk khersonskoho derzhavnoho universytetu. Seriia “psykholohichni nauky”. [Scientific Bulletin of Kherson State University. Psychological Sciences Series] Vol. 3, pp. 49-56 DOI 10.32999/KSU2312-3206 (in Ukrainian)

\section{Information about the author:}

Nataliia Vydolob,

Candidate of Psychological Sciences, Associate Professor, Associate Professor at the Department of Psychology, SHEI "Pereiaslav-Khmelnytsky Grygory Skovoroda State Pedagogical University" 30, Sukhomlynsky str., Pereiaslav, 08401, Ukraine ORCID ID: orcid.org/0000-0003-3564-9179 
NOTES 
NOTES 
Publishing house "Liha-Pres"

9 Kastelivka str., Lviv, 79012, Ukraine 44 Lubicka str., Toruń, 87-100, Poland

Printed by the publishing house "Liha-Pres"

Passed for printing: November 25, 2019.

A run of 150 copies. 